DIOGO GIANCRISTOFORO QUEIROZ

\title{
O PROCESSO DE ENTABULAÇÃO PARA ALAÚdE DE PEÇAS VOCAIS NO SÉCULO XVI: Vincenzo Galilei e a relação entre entabulação e contraponto vocal
}

Dissertação apresentada ao Programa de Pós-graduação em Música do Departamento de Música da Universidade de Brasília, como requisito parcial para obtenção do grau de mestre em música.

Área de concentração: Musicologia

Orientador: Prof. Dr. Alexandre Antunes

BRASÍLIA

10/10/2016 
DIOGO GIANCRISTOFORO QUEIROZ

\title{
O PROCESSO DE ENTABULAÇÃo PARA ALAÚdE DE PEÇAS VOCAIS NO SÉCULO XVI: Vincenzo Galilei e a relação entre entabulação e contraponto vocal
}

\begin{abstract}
Dissertação apresentada ao Programa de Pós-graduação em Música do Departamento de Música da Universidade de Brasília, como requisito parcial para obtenção do grau de mestre em música.

Área de concentração: Musicologia
\end{abstract}

Orientador: Prof. Dr. Alexandre Antunes

Banca Examinadora

Prof. Dr. Alexandre Antunes

Prof. ${ }^{a}$ Dr. ${ }^{a}$ Beatriz Magalhães Castro

Prof. ${ }^{a}$ Dr. ${ }^{a}$ Silvana Scarinci 
Aos meus pais. 


\section{AGRADECIMENTOS}

Nos dois anos em que me dediquei a essa pesquisa, foram muitas as pessoas que contribuíram com ela. Gostaria de agradecer ao meu orientador Alexandre Antunes, que foi imprescindível na criação do texto e proporcionou um desenvolvimento tranquilo para o trabalho. Agradeço também às professoras Beatriz Magalhães Castro e Silvana Scarinci por todas as contribuições. Agradeço a todos da Escola Parque Anísio Teixeira, onde trabalhei durante todo o período de pesquisa, e especialmente à professora Neide Rodrigues pela compreensão e flexibilidade. Agradeço também ao meu professor de alaúde Fernando Dell'Isola que me apresentou o Fronimo. E especialmente aos meus professores e amigos Fernando Lopes e Karla Dias pelas inspirações musicais e extra-musicais. Por fim, agradeço a todos da minha família sem eles teria sido impossível fazer qualquer coisa. E à Rebeca que foi importante de inumeráveis maneiras. 
O real segredo das artes também é esse: ser sempre um principiante.

Shunryu Suzuki 


\section{RESUMO}

A pesquisa concentra-se no processo de entabulação de Vincenzo Galilei e em como o alaudista o relacionava à teoria musical da época. O tratado Fronimo foi escolhido por ser o texto em que Galilei descreve essa relação. $O$ trabalho baseia-se nas principais características do processo de entabulação de Galilei, comparando-o com os processos de alguns outros tratados de entabulação da época. Para compreender como o processo de entabulação se relaciona com as teorias composicionais do século XVI, pesquisou-se dentro dos principais tratados da época as características que se relacionavam com o processo. Por fim, propõe-se uma forma de análise histórica baseada tanto no processo de entabulação como na teoria musical do período. Como exemplo, foi feita a análise da entabulação feita por Galilei e publicada no Fronimo de Io mi son giovinetta de Domenico Ferrabosco.

Palavras-chave: Vincenzo Galilei. Entabulação. Análise. Música renascentista. Alaúde. Teoria musical. Fronimo. 


\begin{abstract}
This research is centered in Vincenzo Galilei's lute intabulation process and in how it was related to sixteenth-century music theory. Fronimo was chosen because it is the treaty in which Galilei describes this relationship. A description of the intabulation process' primary characteristics is compared to other forms of lute intabulation described by other authors from the same century. Next, the compositional theories relevant to the analysis of the music is selected based on the characteristics of the intabulation process. Finally, we offer a form of historic analysis for intabulations based on the relation between Galilei's process and sixteenth-century compositional theory. As an example an analysis of Galilei's intabulation of Domenico Ferrabosco's Io mi son giovinetta was made.
\end{abstract}

Keywords: Vincenzo Galilei. Intabulation. Analysis. Renaissance music. Lute. Music theory. Fronimo. 


\section{LISTA DE FIGURAS}

Figura 1.1 Exemplo de partitura retirado do Fronimo 19

$\begin{array}{lll}\text { Figura 1.2 } & \text { Exemplo de tablatura }\end{array}$

Figura 1.3 Transcrição do exemplo de tablatura da fig. $1.2 \quad 20$

Figura 1.4 Tablatura de alaúde italiana do século XVI com a notação rítmica que 20 indica apenas a mudança de figura

Figura 1.5 Transcrição da tablatura da fig. 1.3 em notação moderna 21

Figura 1.6 Tablatura moderna de guitarra com indicação rítmica 21

Figura 1.7 Superius da canção Helas quel jour de Orlando de Lassus $\quad 22$

Figura 1.8 Tablatura de Helas quel jour, onde pode-se ver todas as vozes notadas em 22 uma única linha

Figura 1.9 Sinais de tenuto em uma entabulação a duas vozes $\quad 24$

Figura 1.10 Transcrição da tablatura do exemplo de tenuto 24

Figura 2.1 Transcrição intermediária e ornamentada de Emmanuel Adriansen 37

Figura 2.2 Helas quel jour de Orlando de Lassus entabulação e grade 39

Figura 2.3 Grade de Galilei com as vozes em posição invertida 40

Figura 2.4 Exemplo de supressão de uma voz na entabulação $\quad 42$

Figura 2.5 Exemplo de supressão de nota transcrição da grade original 42

Figura 2.6 Exemplo de supressão de nota transcrição da tablatura 42

Figura 2.7 Exemplo de transposição de nota para uma oitava mais aguda - grade $\quad 44$

Figura 2.8 Exemplo de transposição de nota para uma oitava mais aguda - tablatura $\quad 44$

Figura 2.9 Exemplo de transposição de nota para uma oitava mais aguda - transcrição 44 da tablatura

Figura 2.10 Exemplo de arpejo em uma entabulação - grade 45

Figura 2.11 Exemplo de arpejo em uma entabulação - entabulação literal 45

Figura 2.12 Exemplo de arpejo em uma entabulação - transcrição da entabulação literal 46

Figura 2.13 Exemplo de arpejo em uma entabulação - entabulação ornamentada 46

Figura 2.14 Exemplo de arpejo em uma entabulação - transcrição da entabulação 46 ornamentada

Figura 2.15 Quadro de Hermann Finck que mostra o âmbito da Gamut 49 
$\begin{array}{lll}\text { Figura 2.16 Posta prima e posta seconda } & 50\end{array}$

$\begin{array}{lll}\text { Figura } 2.17 & \text { Transcrição da posta prima } & 50\end{array}$

$\begin{array}{lll}\text { Figura 2.18 Transcrição posta seconda } & 50\end{array}$

Figura 2.19 Exemplo de uma ornamentação que liga uma voz à outra - grade 57

Figura 2.20 Exemplo de uma ornamentação que liga uma voz à outra - entabulação 57

Figura 2.21 Exemplo de uma ornamentação que liga uma voz à outra - transcrição da 57 entabulação literal

Figura 2.22 Exemplo de uma ornamentação que liga uma voz à outra - entabulação 58 ornamentada

Figura 2.23 Exemplo de uma ornamentação que liga uma voz à outra - trnscrição da 58 entabulação ornamentada

Figura 3.1 Exemplo de contraponto diminuído em tablatura $\quad 65$

Figura 3.2 Transcrição do contraponto diminuído em tablatura 66

Figura 3.3 Inovações no tratamento das dissonâncias de Vincenzo Galilei - Exemplo 67 1.a

Figura 3.4 Inovações no tratamento das dissonâncias de Vincenzo Galilei - Exemplo 1.b

Figura 3.5 Inovações no tratamento das dissonâncias de Vincenzo Galilei - Exemplo 1.c

Figura 3.6 Inovações no tratamento das dissonâncias de Vincenzo Galilei - Exemplo 268

Figura 3.7 Inovações no tratamento das dissonâncias de Vincenzo Galilei - Exemplo 368

Figura 3.8 Inovações no tratamento das dissonâncias de Vincenzo Galilei - Exemplo $4 \quad 68$

Figura 3.9 Inovações no tratamento das dissonâncias de Vincenzo Galilei - Exemplo 568

Figura 3.10 Inovações no tratamento das dissonâncias de Vincenzo Galilei - Exemplo $6 \quad 68$

Figura 3.11 Inovações no tratamento das dissonâncias de Vincenzo Galilei - Exemplo 69 7.a

Figura 3.12 Inovações no tratamento das dissonâncias de Vincenzo Galilei - Exemplo 7.b

$\begin{array}{lll}\text { Figura } 3.13 & \text { Cadências perfeitas } & 70\end{array}$

$\begin{array}{lll}\text { Figura 3.14 Cadências frígias } & 70\end{array}$

$\begin{array}{lll}\text { Figura 3.15 Exemplo de cadência evitada }{ }^{\circ} 1 & 71\end{array}$

$\begin{array}{lll}\text { Figura 3.16 Exemplo de cadência evitada }{ }^{0} 2 & 71\end{array}$ 
$\begin{array}{lll}\text { Figura 3.17 Exemplo de cadência evitada }{ }^{0} 3 & 71\end{array}$

Figura 3.18 Exemplo de cadência evitada $\mathrm{n}^{\circ} 4$

Figura 3.19 Exemplo de cadência evitada ${ }^{0} 5$

Figura 3.20 Exemplo de cadência evitada $n^{\circ} 6$

Figura 3.21 Exemplo de cadência evitada $n^{0} 7 \quad 72$

$\begin{array}{lll}\text { Figura 3.22 Exemplo de cadência evitada }{ }^{\circ} 8 & 73\end{array}$

$\begin{array}{lll}\text { Figura } 3.23 & \text { Oito modos por espécie de oitava } & 74\end{array}$

Figura 3.24 Os 12 modos de Glareanus e os 2 modos dissonantes 76

$\begin{array}{lll}\text { Figura } 3.25 & \text { As finalis de Galilei com bequadro } & 80\end{array}$

$\begin{array}{lll}\text { Figura } 3.26 & \text { As finalis de Galilei com bemol } & 81\end{array}$

$\begin{array}{lll}\text { Figura } 4.1 & \text { Cadência compasso } 6 \text { e } 7 & 83\end{array}$

$\begin{array}{lll}\text { Figura } 4.2 & \text { Cadência compasso } 10 \text { e } 11 & 84\end{array}$

$\begin{array}{lll}\text { Figura } 4.3 & \text { Cadência compasso } 3 \text { e } 4 & 84\end{array}$

$\begin{array}{lll}\text { Figura } 4.4 & \text { Cadência compasso } 16 \text { e } 17 & 85\end{array}$

Figura $4.5 \quad$ Cadência compasso 23 e 24

$\begin{array}{lll}\text { Figura 4.6 Cadência compasso } 31 \text { e } 32 & 86\end{array}$

$\begin{array}{lll}\text { Figura } 4.7 & \text { Cadência compasso } 27 \text { e } 28 & 86\end{array}$

Figura $4.8 \quad$ Cadência compasso 14 e 15

$\begin{array}{lll}\text { Figura } 4.9 & \text { Cadência compasso } 19 \text { e } 20 & 86\end{array}$

Figura 4.10 Exemplo de dissonância compasso $16 \quad 88$

Figura 4.11 $\quad$ Exemplo de dissonância compasso $21 \quad 88$

Figura 4.12 Exemplo de dissonância compasso $22 \quad 88$

Figura 4.13 Exemplo de dissonância compasso 24

Figura 4.14 Exemplo de dissonância compasso 6

Figura 4.15 Exemplo de dissonância compasso $18 \quad 89$

Figura 4.16 Exemplo de dissonância compasso 23

Figura 4.17 Exemplo de dissonância compasso $34 \quad 90$

Figura 4.18 Ornamentação compasso 3 (grade) 91

Figura 4.19 Ornamentação compasso 3 (entabulação) 91

Figura 4.20 Ornamentação compasso 3 (transcrição da entabulação) 91

Figura 4.21 Ornamentação compasso 20 (grade) 91

Figura 4.22 Ornamentação compasso 20 (entabulação) 92 
Figura 4.23 Ornamentação compasso 20 (transcrição da entabulação) 92

Figura 4.24 Ornamentação compasso 27 (grade) 92

Figura 4.25 Ornamentação compasso 27 (entabulação) 92

Figura 4.26 Ornamentação compasso 27 (transcrição da entabulação) 93

Figura 4.27 Ornamentação compasso 35 (grade) 93

Figura 4.28 Ornamentação compasso 35 (entabulação) 93

Figura 4.29 Ornamentação compasso 35 (transcrição da entabulação) 93

Figura 4.30 Nota do baixo oitavada compasso 10 (grade) 94

Figura 4.31 Nota do baixo oitavada compasso 10 (entabulação) 94

Figura 4.32 Nota do baixo oitavada compasso 10 (transcrição da entabulação) 95

Figura 4.33 Ornamentação compasso 12 (grade) 95

Figura 4.34 Ornamentação compasso 12 (entabulação) 95

Figura 4.35 Ornamentação compasso 12 (transcrição da entabulação) 96

Figura 4.36 Exemplo de nota omitida compasso 19 (grade) 96

Figura 4.37 Exemplo de nota omitida compasso 19 (entabulação) 97

Figura 4.38 Exemplo de nota omitida compasso 19 (transcrição da entabulação) 97

Figura 4.39 Exemplo de alteração de duração de nota compasso 22 (grade) 97

Figura 4.40 Exemplo de alteração de duração de nota compasso 22 (entabulação) 97

Figura 4.41 Exemplo de alteração de duração de nota compasso 22 (transcrição da 97 entabulação)

Figura $4.42 \quad$ Exemplo de voz oitavada compassos 15 e 16 (grade) 98

Figura 4.43 Exemplo de voz oitavada compassos 15 e 16 (entabulação) 98

Figura 4.44 Exemplo de voz oitavada compassos 15 e 16 (transcrição da entabulação) 98

$\begin{array}{lll}\text { Figura A.1 } & \text { Entabulação de Io mi son giovinetta }\end{array}$

Figura A.2 Transcrição da entabulação de Io mi son giovinetta (p. 1) 107

Figura A.3 Transcrição da entabulação de Io mi son giovinetta (p. 2) 108

Figura A.4 Grade de Io mi son giovinetta alla quarta bassa (p. 1) 109

Figura A.5 Grade de Io mi son giovinetta alla quarta bassa (p. 2) 110

Figura A.6 Grade de Io mi son giovinetta alla quarta bassa (p. 3) 111

Figura A.7 Transcrição da entabulação intermediária de Adriansen 112

Figura A.8 Transcrição da entabulação ornamentada de Adriansen 112

Figura A.9 Helas quel jour transcrição da grade p.1 113 
Figura A.10 Helas quel jour transcrição da grade p.2 114

Figura A.11 Helas quel jour transcrição da entabulação p.1 115

$\begin{array}{lll}\text { Figura A.12 Helas quel jour transcrição da entabulação p.2 } & 116\end{array}$ 


\section{SUMÁRIO}

CAPÍTULO 1 - GALILEI E CONTEXTO HISTÓRICO 14

$\begin{array}{ll}1.1 \text { - A pesquisa } & 14\end{array}$

1.2 - Galilei teórico 16

$\begin{array}{ll}1.3 \text { - O tratado } & 17\end{array}$

1.4 - Tablatura 19

$\begin{array}{ll}\text { 1.4.1 - Sinal de tenuto } & 23\end{array}$

1.5 - História da música e contexto histórico 25

$\begin{array}{ll}1.6 \text { - Musicologia e performance histórica } & 27\end{array}$

1.7 - Ferramentas para análise $\quad 30$

CAPÍTULO 2 - PROCESSO DE ENTABULAÇÃO 34

2.1 Estágios preliminares $\quad 35$

2.1.1 Grade como estágio intermediário 38

2.2 Entabulação de peças com mais de quatro vozes 40

2.3 Alterações ao contraponto original 42

2.4 As poste $\quad 48$

2.4.1 As poste e as claves

2.5 Musica ficta $\quad 54$

2.6 Ornamentação $\quad 56$

$\begin{array}{lc}\text { 2.7 Significado da entabulação para Galilei } & 60\end{array}$

CAPÍTULO 3 - TEORIA COMPOSICIONAL

3.1 Concepção simultânea

3.1.1 Contraponto x composição

3.1.2 Relação com a entabulação $\quad 64$

3.2 Uso de dissonâncias

3.5 Cadências $\quad 70$

$\begin{array}{ll}\text { 3.6 Modo } & 74\end{array}$

3.6.1 Sistema de oito modos $\quad 74$

3.6.2 Sistema de doze modos 76

$\begin{array}{ll}\text { 3.6.3 Modo na música polifônica } & 78\end{array}$ 
CAPÍTULO 4 - Análise: Io mi son giovinetta

4.1.1 Cadências 83

4.1.2 Modo 86

4.1.3 Novo Método analítico de tipos tonais a partir de uma entabulação $\quad 87$

4.1.4 Dissonâncias $\quad 88$

4.1.5 Adaptações do contraponto vocal ao meio instrumental 90

CAPÍTULO 5 - CONCLUSÃO

$\begin{array}{lr}\text { REFERENCIAS } & 102\end{array}$

$\begin{array}{ll}\text { APÊNDICE } & 106\end{array}$ 


\section{CAPÍTULO 1 - GALILEI E CONTEXTO HISTÓRICO}

\section{1 - A pesquisa}

Uma importante e substancial forma de registro do repertório da música do século XVI é a entabulação de peças vocais. Quase todo esse repertório instrumental está notado em tablatura, principalmente para instrumento de teclado e alaúde. O músico ou musicólogo que trabalha com esse repertório encontra dificuldades relacionadas, principalmente, em aspectos ligados à aplicação prática da teoria musical da época. A pesquisa se ocupará das entabulações de peças vocais para alaúde ${ }^{1}$. A investigação terá como foco principal o tratado escrito por Vincenzo Galilei, Fronimo. Esse tratado expõe o processo de entabulação e descreve como e quais competências um alaudista da época deveria dominar para realizar versões instrumentais bem sucedidas.

No tratado, Galilei descreve como as teorias composicionais da época se relacionavam ao processo de criação de uma entabulação. Essa é a principal razão para a definição do Fronimo como principal objeto de pesquisa, uma vez que os outros tratados de entabulação, com poucas exceções, trazem apenas direcionamentos práticos de como traduzir o texto musical da notação mensural para a tablatura. A relação entre teoria e prática musical feita por Galilei ajuda tanto o musicólogo quanto o instrumentista contemporâneo a ter uma compreensão mais aprofundada do texto musical.

Para aprofundar a compreensão das peças, propõe-se uma perspectiva de análise desenvolvida a partir das práticas e teorias musicais utilizadas por Galilei em seu tratado. Segundo Margaret Bent, em The grammar of early music (1998), a análise das peças deve gerar o diálogo entre o músico ou pesquisador contemporâneo e o texto musical do passado. Para que esse diálogo não esteja desequilibrado, é necessário que o texto musical seja compreendido de acordo com as características que eram observadas na cultura musical em que ele foi criado. Segundo Bent (1998), isso é possível se procurarmos nos aprofundar na teoria musical da época e criarmos as ferramentas de análise baseadas nela.

A inquietação que dá origem à pesquisa é a interação entre os processos de entabulação de peças polifônicas e as teorias composicionais da época e em como elas influenciavam as alterações feitas ao original vocal. A resposta a essa questão parece estar centrada na ideia de se possibilitar

\footnotetext{
${ }^{1}$ Jean-Michel Vaccaro classifica o repertório para alaúde solo do século XVI em quatro tipos diferentes de peças: entabulações de peças vocais com pouca ornamentação, como em Vincenzo Galilei; entabulações muito ornamentadas, no estilo de Adrian Le Roy (1520 - 1598) e Albert de Rippe (1500 - 1551); fantasias baseadas em um modelo vocal; e fantasias livres (VACCARO, 1981, p. 39).
} 
análises historicamente informadas das peças. Para gerar esse modelo de análise buscaremos as seguintes informações no processo de entabulação:

- Como era feita a tradução de um sistema notacional para outro;

- O quão fiel era a entabulação ao texto original;

- A determinação da tessitura a ser utilizada;

- A realização da musica ficta;

- Como eram realizadas as ornamentações;

- Os possíveis usos das entabulações para Galilei.

A leitura do tratado de Galilei e de outros textos relacionados a este tema permitiu que os seguintes aspectos teóricos fossem destacados como relevantes para o processo de entabulação:

- A forma de concepção das peças, se simultânea ou sucessiva;

- O uso das dissonâncias;

- As regras de contraponto;

- Cadências;

- Teoria modal.

O contato com os textos dos tratados do século XVI pode gerar algumas dúvidas por conta das mudanças de significado de algumas palavras, por exemplo, harmonia. O significado desse termo, ainda hoje polissêmico, nem sempre era compartilhado por todos os autores no século XVI. Durante o texto, serão discutidos alguns dos possíveis significados, Bonnie Blackburn, ao discutir o processo de composição das polifonias renascentistas, afirma que Giovanni Spataro (1458? - 1541) utiliza o termo para indicar peças com pelo menos três vozes (BLACKBURN, 2001, p. 9). No entanto, um uso que pode ser encontrado tanto em Spataro e Gioseffo Zarlino (1517 - 1590) está relacionado à alternância entre consonâncias e dissonâncias, uma peça sem consonância não seria considerada harmônica. Zarlino também utiliza o termo para significar uma obra musical completa (BLACKBURN, 1987, p. 230-232).

As obras musicais também não eram referenciadas unicamente por um único termo, essa questão será discutida no capítulo 3.1.1, mas durante a pesquisa o termo "composição", embora anacrônico, será utilizado como sinônimo de obra musical, assim como processo composicional será utilizado para tratar do método de composição utilizado pelos músicos do século XVI. Outros 
dois termos que serão utilizados com o significado diferente da acepção do século XVI são os termos teoria composicional e grade.

Durante a pesquisa, o termo "teoria" não será utilizado da mesma forma como no século XVI, quando ele era utilizado para opor duas formas de entender a música musica pratica e musica teorica. Essa última estava relacionada à forma como a música podia ser, enquanto ciência, compreendida dentro das observações do mundo natural, com por exemplo na explicação dos pitagóricos para as consonâncias e dissonâncias. Na pesquisa, ele será utilizado de acordo com seu uso comum na contemporaneidade.

“Grade” faz referência à notação de pautas superpostas para músicas polifônicas. O termo é anacrônico, mas acredito que ele facilita a compreensão do texto. Encontramos nos tratados do século XVI vários termos similares a partitura, por exemplo, score que aparece no tratado de Adrian Le Roy ${ }^{2}$, que fazem referência a grades, mas referenciar às grades simplesmente como partitura parece ser menos preciso e pode gerar ambiguidade de sentidos para o leitor moderno, por esse motivo será utilizado o termo grade para significar uma partitura com várias pautas.

\section{2 - Galilei teórico}

Vincenzo Galilei ${ }^{3}$ se destacava dentre seus contemporâneos pela importância de seus estudos teóricos. Podemos observar, principalmente na segunda metade de sua vida, sua preocupação com a difusão da teoria musical como maneira de garantir a qualidade da música produzida. Essa preocupação parece ter sido estimulada pelo contato com dois importantes teóricos do período Gioseffo Zarlino e Girolamo Mei. Em 1544, Galilei já havia perdido seus pais e nesse momento o Conde Bardi o recebe sob sua proteção. Foi com apoio financeiro de Bardi que Galilei vai a Veneza estudar com Gioseffo Zarlino ${ }^{4}$. Nesse momento, Galilei entra em contato com a teoria musical que o ajudaria a desenvolver seus principais trabalhos.

No ano de 1562, Galilei muda-se para Pisa. Nesse período começa a dar aulas de alaúde para alunos da Università di Pisa, com o intuito de sustentar sua recém formada família. É nesse período

\footnotetext{
${ }^{2}$ A primeira edição do tratado de Le Roy está perdida, conhecemos o tratado por meio das traduções inglesas publicadas em 1568 e 1574.

${ }^{3}$ Não se pode precisar a data de nascimento de Galilei, mas estima-se que Galilei nasceu entre 1520 e 1532 . Os registros de batismo da paróquia de Santa Maria a Monte, onde ele nasceu, só possui os registros dos nascimentos ocorridos a partir de 1532 (CANGUILHEM, 2001, p. 18).

${ }^{4}$ Até o presente momento, pesquisas musicológicas não conseguiram datar precisamente quando ou por quanto tempo se deu o contato entre Zarlino e Galilei. Entretanto, com base em uma carta mencionada por Zarlino nos Sopplimenti musicali de 1588, estima-se que este período de estudos de Galilei ocorreu antes de 1565, ano em que Zarlino assumiu o posto de mestre de capela na catedral de San Marco.
} 
que Galilei começa a escrever uma obra dedicada ao processo de entabulações de peças vocais. Vincenzo, assim como Zarlino, estudava as traduções dos principais teóricos musicais da Grécia antiga. No entanto, Galilei discorda das interpretações apresentadas por seu antigo professor. Por recomendação do Conde Bardi, Galilei entra em contato com outro estudioso do tema, Girolamo Mei (1519 - 1594). A influência de Mei foi definitiva para as divergências que o compositor sustentaria com seu antigo professor. A partir da década de 1580, quase todas as publicações de Galilei seriam dedicadas a essa disputa com Zarlino. A principal publicação de Galilei nesse período foi o Dialogo della musica antica et della moderna, que se tornou uma das principais bases teóricas utilizadas pela Camerata Fiorentina.

A posição de Galilei enquanto teórico traz importantes contribuições acerca de como a música para alaúde estava inserida nas transformações que aconteciam na música no século XVI, entre elas, o processo de composição. O debate acerca desse tema discute se as vozes da polifonia eram compostas simultaneamente ou sucessivamente e se a estrutura da peça era concebida de forma diádica ou triádica. A análise das entabulações pode ajudar a posicionar compositores e peças do século XVI dentro desse debate.

\section{3 - O tratado}

O tratado, Fronimo, foi publicado pela primeira vez em 1568 e foi reeditado em 1584 com alterações. Atualmente, além das digitalizações disponibilizada pela Bibliothèque Nationale de France das duas edições do tratado, existem o fac-símile da edição de 1584 publicado pela Forni Editore e a tradução de Carol McClintock para a língua inglesa, publicada pelo American Institute of Musicology em 1985. Galilei escreve esse tratado em forma de diálogo. O dois personagens são Fronimo, que é um músico e professor, e Eumatio, um aluno. Ambos se encontram no início do diálogo, quando Eumatio pede a Fronimo que esse lhe ensine a arte de fazer entabulações de peças vocais. Fronimo é certamente o mais extensivo tratado acerca dessa arte, com quase duas centenas de passagens. Essa característica não era comum aos outros tratados da época acerca desse tema, como por exemplo, o tratado publicado por Michele Carrara (? - 1585) no ano seguinte à publicação da segunda edição do Fronimo que possuía apenas uma página.

Fronimo é um tratado que ocupa uma posição peculiar dentro da obra de Vincenzo Galilei. O assunto principal do livro é a música polifônica, que o autor havia criticado no Dialogo della musica antica et della moderna, publicado três anos antes da segunda edição do tratado. $\mathrm{O}$ 
musicólogo Philippe Canguilhem, em sua tese de doutorado acerca do tratado, questiona a razão que teria levado Galilei a reeditar esse tratado três anos depois da publicação do Dialogo, que critica o gênero composicional presente no Fronimo. Segundo Canguilhem (2001, p. 223), a posição que Galilei adotou no Dialogo restringia-se à música cantada, que deveria adequar-se ao texto, a música polifônica - ainda que esta fosse considerada inferior pelo compositor - adequava-se perfeitamente a composições instrumentais, portanto a prática da entabulação de peças vocais era para ele perfeitamente justificada 5 .

Segundo Canguilhem (2001, p. 222), o tratado de Galilei pode ser separado dos demais tratados de entabulação do século XVI, porque ele — em sua primeira edição — já inaugurava uma nova forma de utilização da tablatura para alaúde. Este, diferente da maioria dos tratados de entabulação do século XVI, que ensinavam de uma forma mais superficial a transformar as polifonias vocais em peças para alaúde solo, tinha como objetivo ensinar contraponto e composição aos instrumentistas. Com efeito, as entabulações presentes no tratado, somadas às informações do texto, dão conta das principais teorias composicionais da época ${ }^{6}$. Esse objetivo fica ainda mais claro na edição de 1584, na qual ele acrescenta um pequeno tratado de contraponto ao Fronimo.

A principal contribuição do tratado para a pesquisa sobre entabulações de música vocal é o fato de Galilei demonstrar como o conhecimento das técnicas de composição de música vocal são essenciais para a criação das versões instrumentais. Isso é de grande interesse para o músico contemporâneo, uma vez que o crescente distanciamento temporal à época em que as peças foram compostas criam lacunas que deixam de existir após a investigação da teoria musical utilizada para a criação dessas mesmas obras. Utilizaremos o trabalho de Galilei como guia para entender como essas teorias eram aplicadas às entabulações de peças vocais.

\footnotetext{
5 Posteriormente, Canguilhem relativizaria a dicotomia entre contraponto e monodia acompanhada (CANGUILHEM, 2007, p. 33).

${ }^{6}$ Todas as características citadas na página 15 são contempladas de alguma forma no tratado por Galilei.
} 


\section{4 - Tablatura}

Segundo Dart et all (2015, p. 1), O termo tablatura começou a ser utilizado para designar registros de notação musical que estivessem condensados em um único sistema. A notação em partitura foi criada para a monodia, enquanto que as tablaturas para a polifonia. A principal característica que diferencia a tablatura do sistema de notação em partitura é que na primeira são utilizados dois sinais: um para indicar a altura da nota, que, no alaúde, é a posição em que a nota deve ser executada, e outro sinal para indicar a duração da nota. Na partitura, um sinal indica tanto a altura da nota quanto a sua duração. Na figura 1.1, Galilei mostra um exemplo de uma entabulação de uma passagem a duas vozes. Pode-se perceber como na tablatura temos a relação entre as vozes mais perceptível, uma vez que ambas estão escritas em um mesmo sistema. Na edição de partituras no século XVI, não era costume alinhar verticalmente as notas que aconteciam de forma simultânea nas vozes diferentes (figura 1.1), mais além não era costume o uso de grades para execução musical, cada parte era notada individualmente em livros de partes ou livros corais.

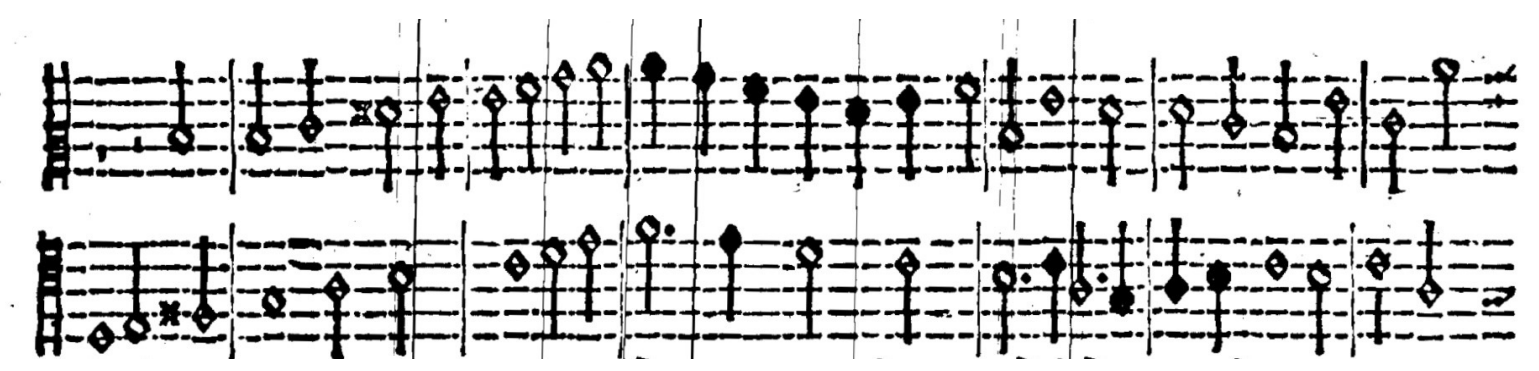

Fig 1.1. Exemplo de partitura retirado do Fronimo. (GALILEI, 1584, p. 12)

Ao registrar a música em tablaturas, as relações temporais entre as partes ficam evidentes, porque as notas que são tocadas simultaneamente devem estar alinhadas verticalmente (figura 1.2).

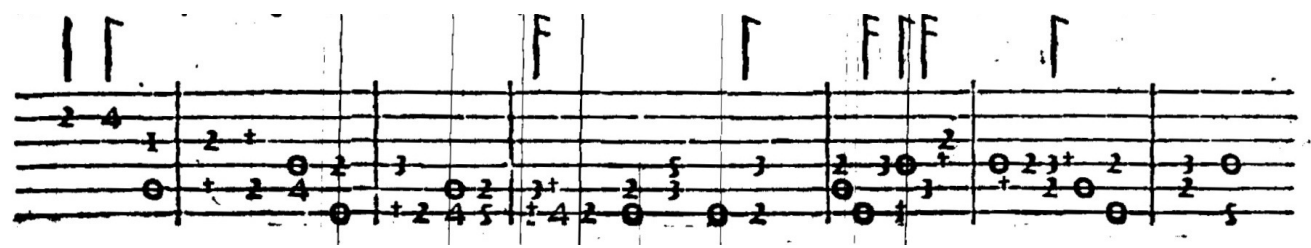

Fig. 1.2. Exemplo de tablatura (GALILEI, 1584, p. 12) 

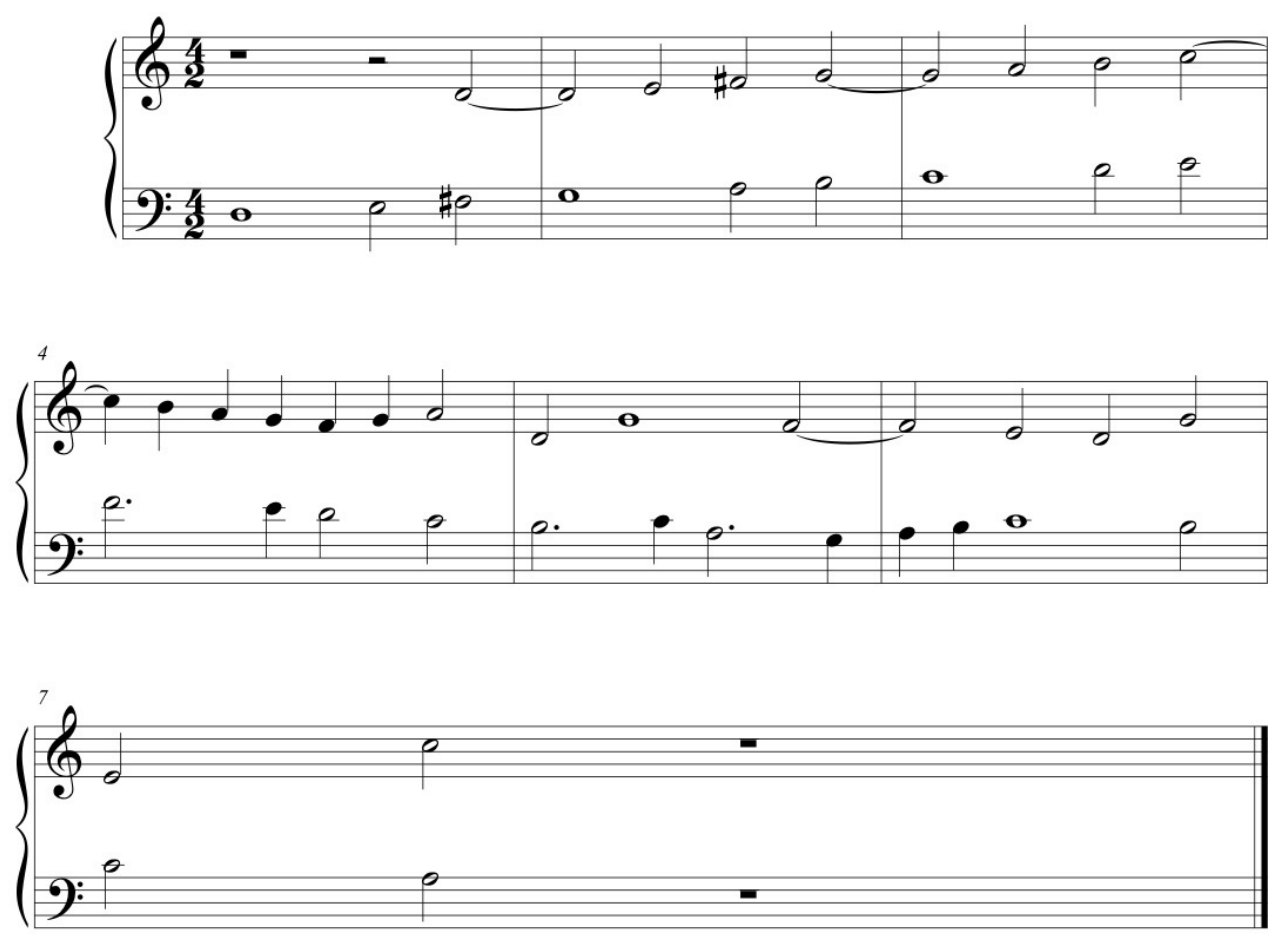

Fig. 1.3. Transcrição do exemplo de tablatura da fig. 1.2 (GALILEI, 1584, p. 12).

No entanto, a escrita polifônica em tablatura de alaúde tem uma desvantagem em relação à notação em partitura, porque só existe uma indicação de ritmo para todas as vozes. Pode-se ver um exemplo disso na figura 1.4. Ao comparar a tablatura da Fantasia de Francesco da Milano (1497 1543) com sua transcrição para notação moderna (fig. 1.5), percebe-se logo no segundo compasso, quando entra a segunda voz, que a indicação rítmica é de uma mínima, no entanto a segunda voz dura uma semibreve. Isso acontece porque a maioria das tablaturas para instrumentos de cordas dedilhadas são compostas por linhas que representam as cordas do instrumento e números ou letras que representam a posição em que o instrumentista deve pressionar a corda. Já a forma de registro da duração é homométrica, portanto a indicação rítmica é a menor duração resultante do somatório das vozes, o que dificulta a compreensão das vozes independentemente, uma vez que a duração de cada nota deve ser interpretada pelo instrumentista.

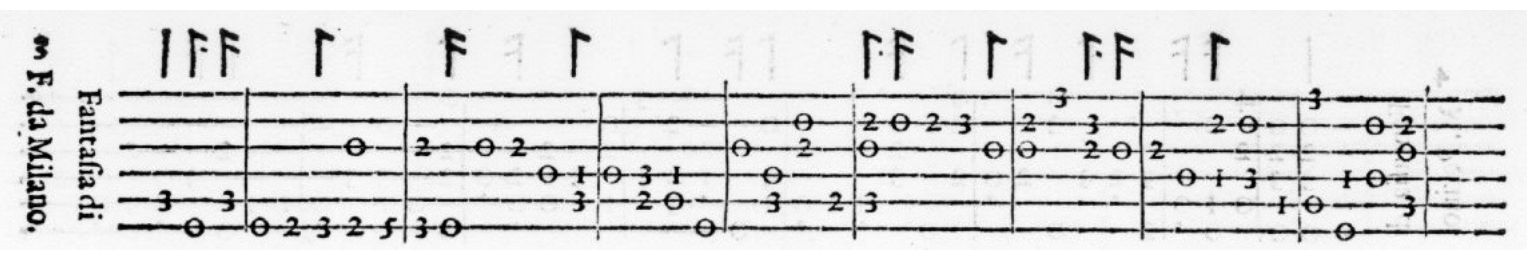

Figura 1.4 - Tablatura de alaúde italiana do século XVI com a notação rítmica que indica apenas a mudança de figura. (FRANCESCO DA MILANO, 1562, fol. 3). 

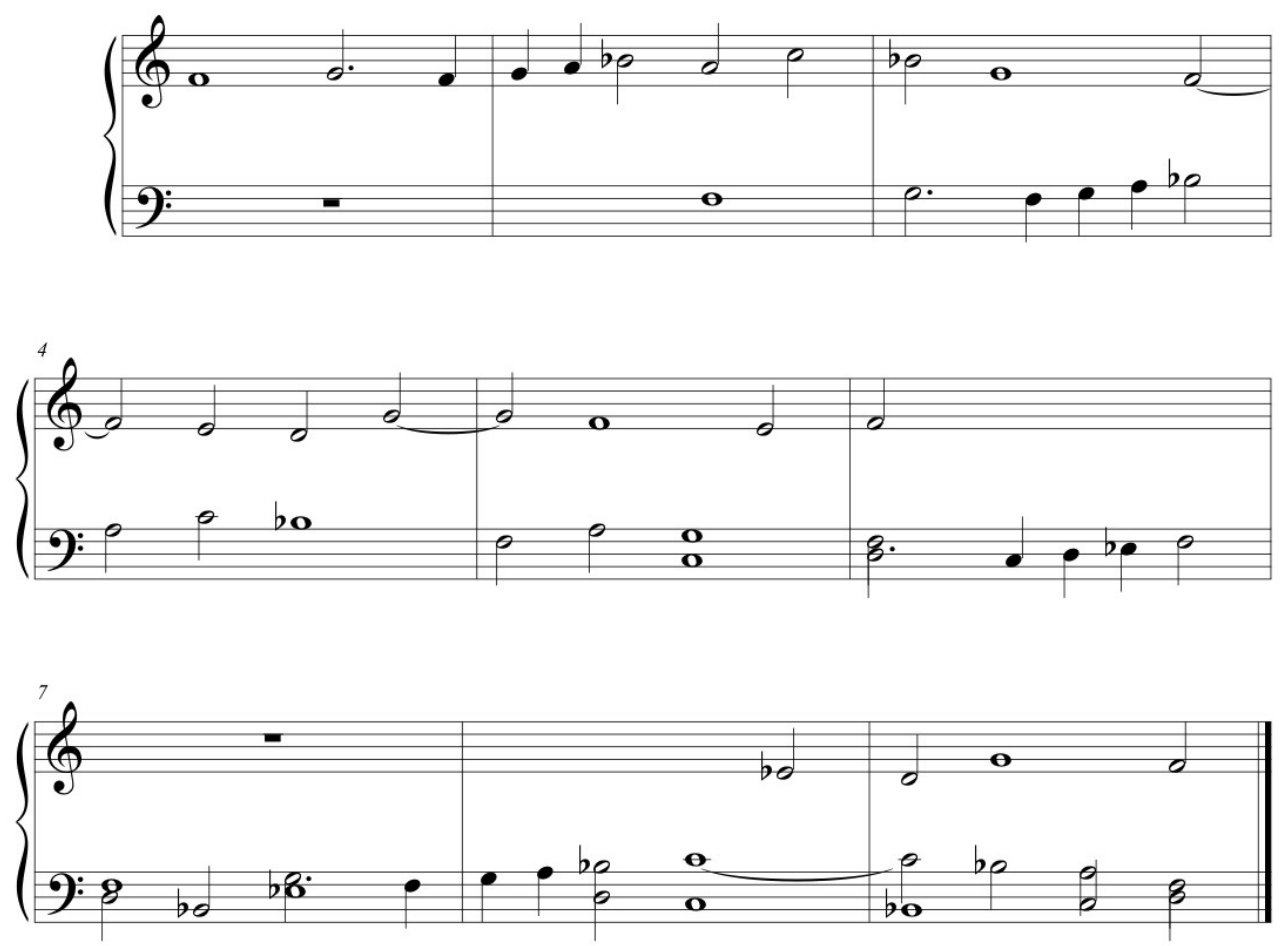

Fig. 1.5. Transcrição da tablatura fig. 1.3 em notação moderna (FRANCESCO DA MILANO, 1562, fol. 3)

A escrita musical em forma de tablatura tem sido utilizada para registrar música para diversos instrumentos, e os instrumentos de cordas dedilhadas e de teclado, por serem muito apropriados à música polifônica, foram os que mais se aproveitaram dessa forma de notação. Atualmente, ela é utilizada principalmente por instrumentos de cordas dedilhadas. $\mathrm{O}$ formato atual das tablaturas ainda guarda muitas semelhanças com as primeiras tablaturas utilizadas na Itália e na Espanha do século XVI, como pode ser visto ao compararmos uma tablatura antiga (fig. 1.3) com uma moderna (fig. 1.6).

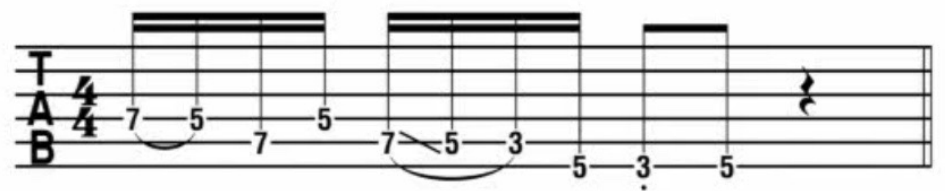

Figura 1.6 - Tablatura moderna de guitarra com indicação rítmica.

Essa dificuldade de interpretação da duração de cada nota tem grande relevância para a interpretação da música para alaúde. Uma vez que a maior parte do repertório instrumental do século XVI é composta por adaptações de peças vocais polifônicas, a realização sonora dessas 
peças prevê a compreensão individual de cada voz, o que em muitos casos é dificultada justamente por conta de uma compreensão imprecisa da duração das notas.

As tablaturas, para além de sua utilização na performance, eram utilizadas para difundir e registrar o repertório da época. Hiroyuki Minamino (1988, p. 35-36) lembra que Vincenzo Galilei era um grande colecionador de músicas e costumava guardá-las na forma de tablaturas. Juan Bermudo (1510 - 1565) dá uma indicação de que essa era uma das formas preferidas para o registro do repertório polifônico, por ser mais econômico, uma vez que todas as vozes estão notadas em um único sistema (BERMUDO, 1555, fol. 83). No século XVI, o sistema de notação utilizado para as polifonias vocais consistia em livros de partes ou livros corais. Como pode ser visto na figura 1.7, esse estilo de notação utiliza uma grande quantidade de papel para ser registrada.

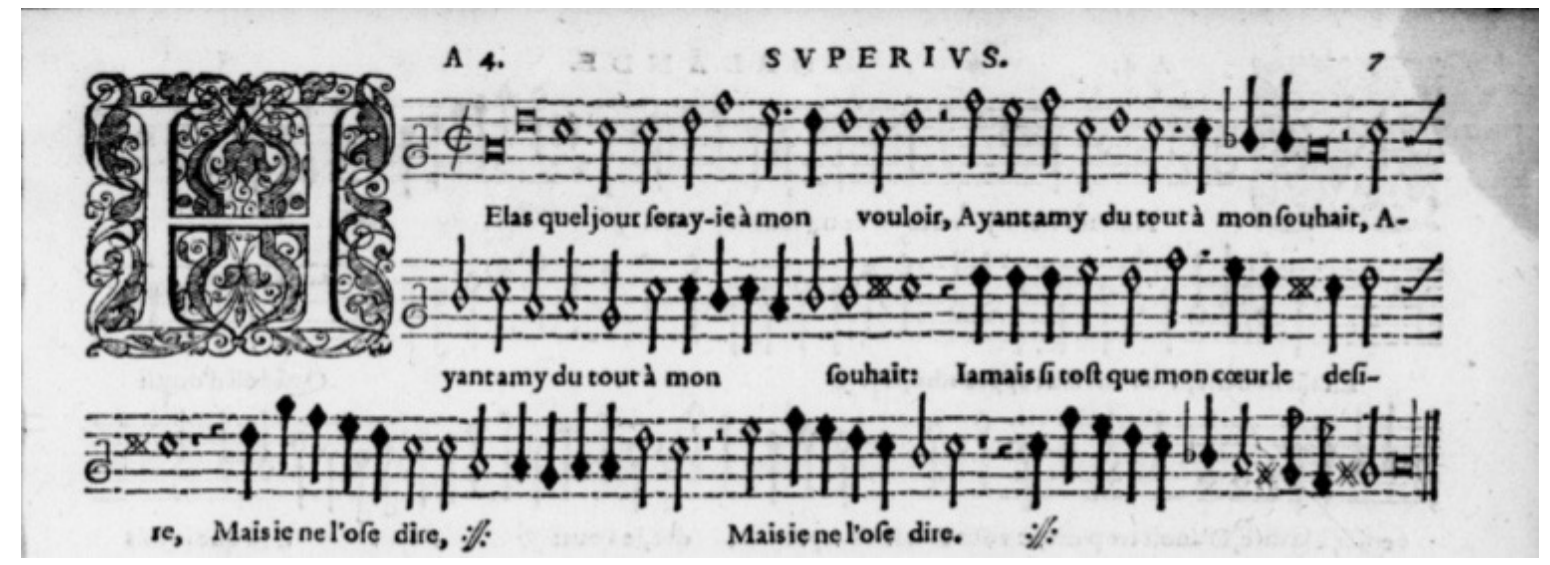

Fig. 1.7. Superius da canção Helas quel jour de Orlando de Lassus

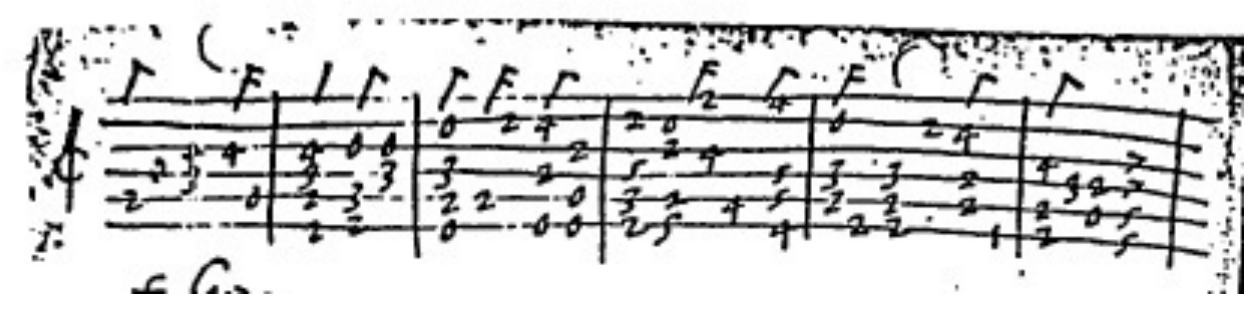

Fig 1.8. Tablatura de Helas Quel Jour, onde pode-se ver todas as vozes notadas em apenas uma única linha.

No exemplo da figura 1.7, pode-se perceber como nos livros de partes cada voz era notada em um livro separado. Nesse caso, apenas para o Superius, foram necessárias três linhas. Ainda que as partituras estivessem notadas em grade, a tablatura seria mais econômica porque todas as vozes 
estão notadas em uma única linha, como pode ser visto na figura 1.8. Esse fato demonstra a importância da compreensão dos processos de transformação de uma polifonia vocal em uma peça para instrumento solo, já que uma grande parte do repertório alaudístico do século XVI encontra-se registrado dessa maneira.

Segundo Minamino (1988, p. 28), a entabulação era uma prática comum aos alaudistas profissionais, que possivelmente as aprendiam oralmente de seus mestres e as transmitiam da mesma forma para seus discípulos. Essa é a provável razão para o pequeno número de tratados que abordam essa arte. No entanto, os tratados escritos acerca do tema no século XVI obtiveram bastante sucesso, principalmente o de Vincenzo Galilei e o de Adrian Le Roy, que foram editados e publicados mais de uma vez.

\subsection{1 - Sinal de tenuto}

O sinal de tenuto (figura 1.9) é representado por uma pequena cruz (picciola croce) ao lado de um número na tablatura. Já utilizado anteriormente por outros alaudistas, indica que a nota tocada anteriormente ao sinal deve continuar sendo pressionada. Ele tem um significado muito importante para Galilei, pois, segundo o autor, o sinal possibilita que se reencontre a versão em partitura $(1568$, p.13) e que qualquer alaudista e contrapontista competente possa descobrir como as dissonâncias foram acomodadas e resolvidas (1584, p. 14). Essas duas características do trabalho de Galilei são importantes para a tese de Canguilhem, para ele Galilei não considerava que as entabulações serviam apenas à performance, mas também ao estudo da teoria musical (CANGUILHEM, 2001, p. 67).

O sinal de tenuto, portanto, foi utilizado pelos alaudistas do século XVI como uma forma de reduzir a maior desvantagem desse tipo de notação de música polifônica, que é a dificuldade de se precisar visualmente a duração de cada nota. É interessante notar novamente que Galilei afirma que qualquer alaudista e contrapontista competente pode, com ajuda do sinal de tenuto, recriar a partitura original. Esta pode ser uma confirmação de que, para Galilei, a competência como contrapontista está ligada à excelência da execução instrumental.

Fro. Esse sinal da pequena cruz (picciola croce), nas minhas entabulações, não significa, como em muitas outras, apenas que devemos manter parado o dedo naquela posição, e mostrar que aquela onde ele está não se move, mas ele é por mim acomodado com tal arte, que qualquer contrapontista, e alaudista pode por meio dele compreender como foram acomodadas e resolvidas as dissonâncias, e como foram colocadas juntas as partes, e ao considerarem todo o artifício e quão bem esse se encontra: não menos que se tivessem à sua frente as notas dispostas da forma que vê no Duo, e podem, com facilidade, extrair as 
mesmas distintas em qualidade e quantidade da parte da qual essa entabulação foi feita por mim, e servir-se, delas da forma que quiserem (GALILEI, 1584, p. 14)7.

O uso do tenuto não era incomum na Itália do século XVI, embora não fosse utilizado por todos os alaudistas. O compositor e alaudista Antonio Rotta em seu Libro primo de Intavolatura, publicado em 1546, faz uso extensivo desse sinal, provavelmente ele se enquadraria no grupo que Galilei afirma utilizar o sinal para demonstrar apenas que uma parte não está se movendo. Galilei, no entanto, considera que o uso correto deve indicar mais que isso, ele deve ser usado para indicar dissonâncias e no seu uso mais importante, para garantir que qualquer que domine as técnicas de contraponto possa recriar a versão em partitura a partir da entabulação.

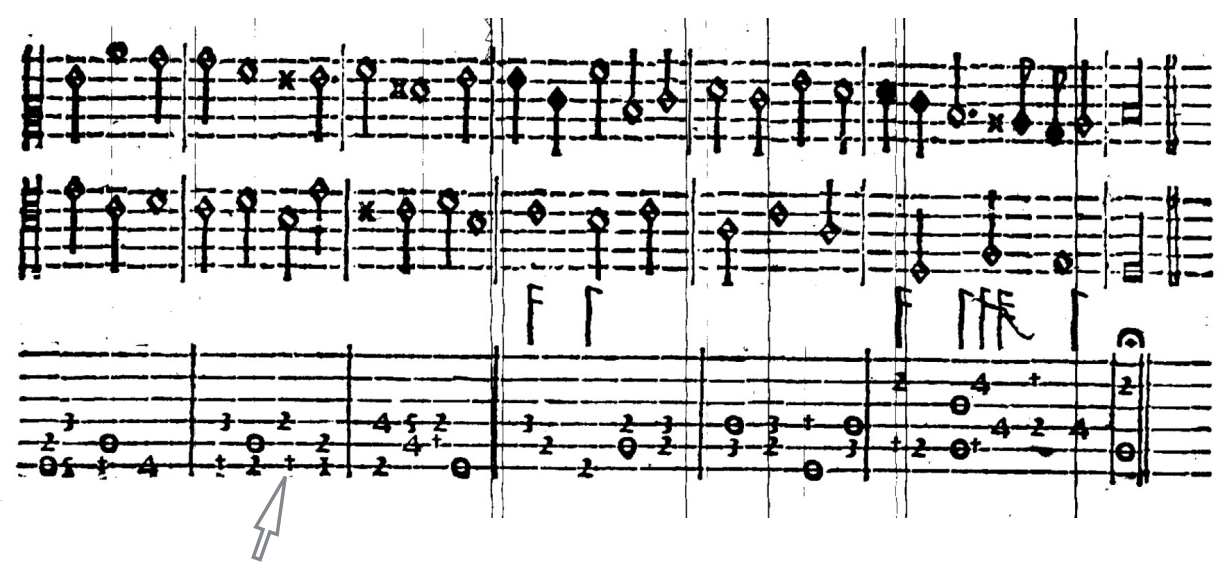

Figura 1.9 - Sinais de tenuto em uma entabulação a duas vozes (GALILEI, 1584, p. 13).
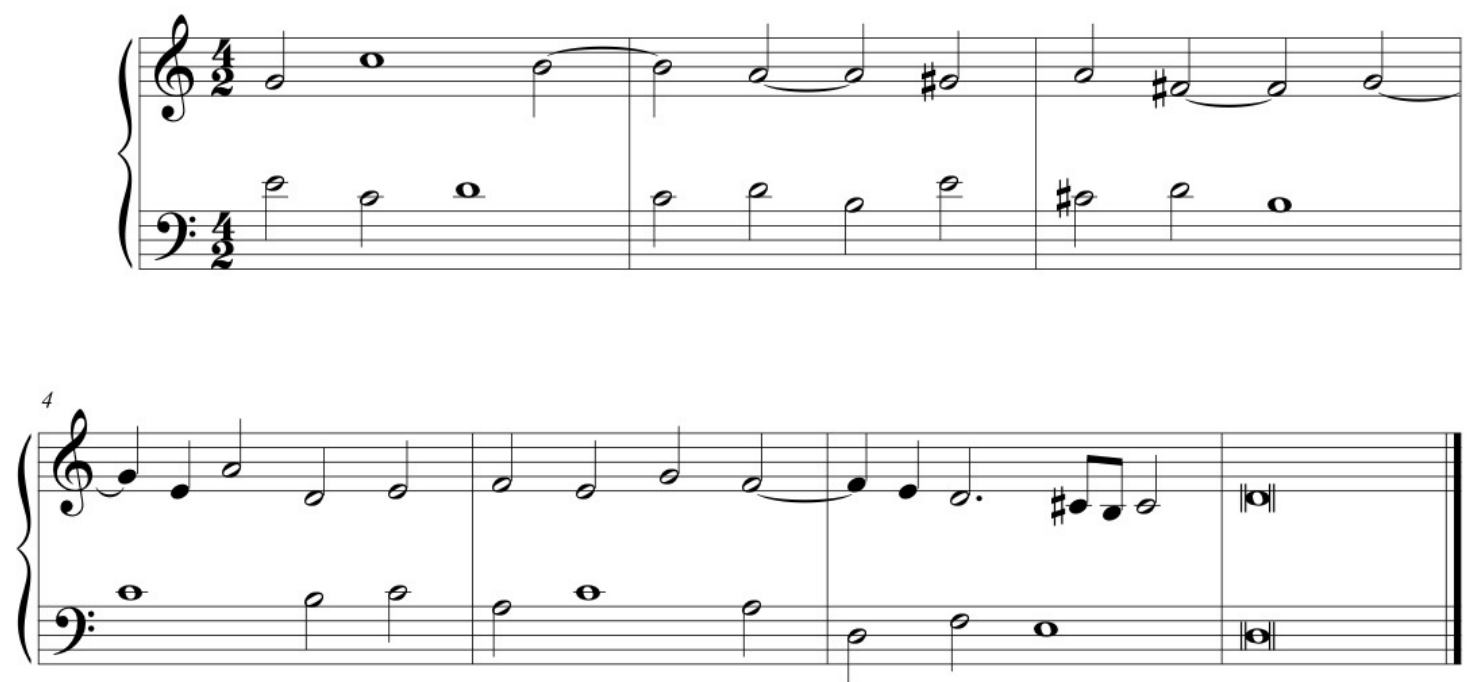

Fig 1.10. Transcrição da tablatura do exemplo de tenuto.

\footnotetext{
${ }^{7}$ Fr. Quel segno di quella picciola croce, nelle mie intavolature, non vuoi solo significare come in molt'atre il tener fermo in quel luogho il ditto, \& manifestare che quella parte dov'egl'è non si muove, ma vi è da me accomodato con tal arte, che può ciascuno perito contrapuntista, \& sonator di liuto col suo mezzo, scorger come in esse siano accomodate $\&$ resolute le dissonanze, \& come siano conlegate insieme le parti, \& considerare minutamente tutto 1'artificio \& quanto di buono in esse si ritrova: non meno che s'egli havesse inanzi l'istesse notte spartite nella maniera che si vedono nel Duo sudetto, $\&$ in oltre può agevolissimamente trarne l'istesse note distinte in quella quantita, \& qualita, di parte, dalle quali esse intavolature furno da me tratte, \& servisene dipoi per qual si voglia suo comodo (GALILEI, 1584, p. 14).
} 


\section{5 - História da música e contexto histórico}

Segundo Leo Treitler (1984, p. 365), a pesquisa em musicologia histórica não deve ser uma narrativa teleológica que entende o presente como uma consequência inevitável dos acontecimentos do passado. Esse tipo de pesquisa preocupa-se apenas com as causalidades e com as mudanças e não privilegia os significados. Ela limita-se a criar uma narrativa unilinear que descreve transformações da sociedade. Nas pesquisas musicológicas, ela pode ser observada em boa parte das interpretações do início do século que apresentam a história da música como uma sequência de mudanças paradigmáticas em direção ao tonalismo e depois sua inevitável dissolução no final do século XIX. Segundo Treitler (1984, p. 368), a alternativa para as narrativas teleológicas parece ser a não-linearidade das análises estruturalistas, no entanto essa forma de análise exclui o estudo de ações individuais.

Treitler, no entanto, defende que alguns objetos da musicologia histórica podem ser melhor descritos narrativamente, uma vez que a análise desses objetos é centrada em mudanças (TREITLER, 1984, p. 368). O exemplo oferecido pelo musicólogo americano foi a sua própria pesquisa sobre a origem da escrita musical na Europa medieval. Ele afirma que, por se tratar de uma pesquisa sobre uma cultura dinâmica em transformação, a escrita narrativa era adequada. Ele ressalta que, ainda assim, devemos ter cuidado para que, embora o conteúdo da pesquisa seja selecionado por uma demanda presente, o resultado da pesquisa não pareça ser a inevitável consequência das mudanças ocorridas. Para que isso aconteça, é necessário que o pesquisador realize uma análise do objeto, que o considere enquanto criação individual e ainda o contexto em que está inserido, ou seja, deve levar-se em consideração tanto as características musicais quanto as extra-musicais.

Lydia Goehr, em seu artigo, Writing music history (1992 p. 182-199), ao descrever a metodologia de pesquisa de três musicólogos (Carl Dalhaus, Leonard B. Meyer e Leo Treitler), afirma que os três consideram as músicas parte das culturas em que estão inseridas, portanto devese lembrar que alguns aspectos dessa cultura marcam, de alguma forma, a prática musical pesquisada. Essa maneira de enxergar a história da música surge da crítica ao positivismo ${ }^{8}$ que atravessa a musicologia na segunda metade do século XX. As três formas de conceber a história da música envolvem uma relação entre aspectos musicais e extra-musicais, segundo a autora (GOEHR, 1992, p. 185). Goehr (2007, p. xvii-xxx) afirma que o desejo de separar o fazer musical dos

\footnotetext{
${ }^{8}$ Essencial para compreender a crítica ao positivismo na musicologia é o livro de Joseph Kerman, Musicologia, publicado em português no ano de 1987.
} 
aspectos extra-musicais surge no final do século XVIII, quando o conceito de obra musical começa se consolidar em músicas que não deviam ter nenhuma função ou característica extra-musical. No entanto, no século XVI, a música estava intrinsecamente ligada à sociedade e aos rituais em que ela acontecia.

A pesquisa musicológica de peças do século XVI necessariamente precisa levar em consideração o contexto em que ela foi criada, uma vez que essa era a concepção dos teóricos e dos músicos da época. A relação entre o número sonoro ${ }^{9}$ de Zarlino e sua percepção da relação da natureza com a música é uma evidência dessa concepção. Essa visão pitagórica de mundo é um exemplo da influência de características extra-musicais no fazer musical do século XVI. Características da cultura desse século, como o humanismo e a predileção pelos ideais helenísticos, serviam de fundamentação para criação das teorias e práticas musicais. Dessa forma, algumas das teorias podem ser compreendidas mais facilmente se a relação entre a teoria e o contexto cultural em que ela existia é esclarecida.

Treitler afirma que, ao deixarmos de perceber o objeto histórico como algo no passado, que poderia ser descrito objetivamente, corremos dois riscos: o primeiro é o de contextualizar tão densamente o objeto pesquisado ao ponto de torná-lo invisível, o segundo é deixar o texto acerca do objeto ser mais relevante do que o objeto pesquisado (TREITLER, 2001, p. 357). No caso de pesquisas musicológicas, podemos acrescentar a contribuição de Lydia Goehr para chegarmos à conclusão de que teremos, nos textos musicológicos, a disputa entre descrições de características musicais e a contextualização por meio de características extra-musicais. O êxito em evitar os excessos descritos por Treitler passa pela capacidade de distinguir entre três categorias descritas por Goehr (1992, p. 188-189) em seu artigo:

- a categoria dos elementos essencialmente musicais;

- a dos extra-musicais;

- a dos não musicais.

Essas categorias são baseadas nas propriedades desses elementos. Na primeira categoria, os elementos têm propriedades que pertencem unicamente ao campo da música; a dos extra-musicais possui elementos com propriedades que pertencem tanto ao campo da música quanto a outros

\footnotetext{
${ }^{9}$ Segundo Rivera, Zarlino considerava tudo que era harmonico em música tinha relação com esse número. Essa teoria de Zarlino era baseada no número seis, que segundo o teórico renascentista era o primeiro número perfeito, portanto toda a arte de composição musical deve ser guiada pelo senario (RIVERA, 1995, p. 148).
} 
campos; a categoria dos elementos não musicais existe em oposição a dos musicais, ou seja, todos os outros elementos que não pertencem ao campo da música (GOEHR, 1992, p. 188).

Margaret Bent (1998, p. 17) divide a forma como utilizamos o contexto histórico das obras musicais em duas categorias: conteúdo biográfico e aplicação de teorias históricas contemporâneas às músicas. Ela considera que, embora o contexto biográfico possa eventualmente trazer informações pertinentes à análise de uma peça, na maior parte das vezes, são as teorias musicais que poderão ajudar a conhecer melhor a música. Podemos considerar, dentro das categorias de Goehr, que as teorias seriam classificadas como elementos essencialmente musicais.

Treitler afirma que, quando tomamos o objeto musical de pesquisa em seu contexto cultural, devemos definir com precisão o objeto de pesquisa. Seriam obtidos resultados diferentes para pesquisas que tivessem como objeto: 1) a performance de uma peça que ocorreu em algum momento no passado, 2) a própria peça registrada em algum sistema de notação, 3) uma performance contemporânea dessa peça que a interpreta a partir do sistema de notação utilizado para registrá-la (TREITLER, 1990, p. 306). Isso, porque, cada um desses objetos de pesquisa citados por Treitler, embora possam parecer similares (todos poderiam concernir a mesma obra musical), está inserido em um contexto diferente que é justamente o que diferencia um do outro. Essa forma de compreender o objeto de pesquisa da musicologia histórica representa um dos mais importantes avanços das últimas décadas para o campo, que, enquanto considerava a obra musical separada de seu contexto, não era capaz de diferenciar entre esses objetos de pesquisa.

\section{6 - Musicologia e performance histórica}

O pensamento histórico sobre a música traz, hoje, vários questionamentos, seja por sua relação com outras disciplinas, seja pela própria prática musical iniciada com o movimento da performance histórica. Em ambos os casos, a relação com o texto musical tem grande importância. No primeiro, relaciona-se o texto musical com a construção de um texto historiográfico. No segundo caso, temos o confronto do texto musical com a prática interpretativa de um sujeito que possui sua própria história.

A percepção de músicas do passado são realizadas atualmente, pelo menos em parte, por meio da prática de intérpretes historicamente informados, o que aumenta a subjetividade de nossa relação com essas peças. As novas epistemologias que cercam a pesquisa em música ampliam o campo de pesquisa, mas também trazem com essa ampliação alguns condicionantes como explicita Ana Cláudia Assis: 
As construções teóricas e as interpretações decorrentes, via de regra, não possuem o grau de certeza a que estão acostumadas as ciências, mesmo as ciências humanas, o que requer do pesquisador em música um aprendizado em lidar com conclusões menos totalizantes, talvez mais frágeis e condicionadas (ASSIS et al., 2009, p.19).

Esse aumento de subjetividade influencia as opções do pesquisador, que sempre tomará decisões relacionadas a anseios do presente, o que, segundo Assis, fragiliza o grau de certeza e a possibilidade de generalização dos resultados das pesquisas.

Treitler (1990, p. 299-319) faz uma interessante análise sobre como o movimento da performance histórica traz nova luz para as pesquisas em musicologia histórica. Por ser uma prática iniciada no século XX, a performance histórica passa a ser uma atividade desenvolvida pelo intérprete historicamente informado que encontra um texto musical não autônomo, tanto em sua concepção passada quanto em seu projeto de recriação presente. Por não se tratar de uma recriação do passado e, sim, de uma criação contemporânea baseada na expectativa contemporânea da obra, existe a compreensão de que não existe uma busca pela expressão autêntica do texto. A autenticidade tornou-se sem significado a partir do momento em que a separação entre sujeito e objeto deixa de ser interessante, ou seja, texto e intérprete se influenciam mutuamente para criar a execução (TREITLER, 1990, p. 315-316).

Treitler procura diferenciar, sem considerar a busca pela autenticidade, a performance histórica das demais formas de performance. A diferença está no fato de que os intérpretes historicamente informados consideram a historicidade do texto musical. Treitler afirma ainda que interpretações tradicionais (desvinculadas do movimento de performance histórica) de peças antigas possuíam sua história e sua própria historicidade, no entanto não levavam em consideração a historicidade da obra (TREITLER, 1990, p. 317). Se considerarmos que uma parte desses intérpretes compartilha a ideia de autonomia e atemporalidade das obras musicais, ou seja, hipervaloriza as características estéticas sobre as históricas ${ }^{10}$, a escolha parece lógica.

Outra contribuição ressaltada por Treitler, acerca do contato com o texto musical, corrobora a afirmação de Laurence Dreyfus (1983, p. 297-322) de que o intérprete se move entre dois polos, o primeiro é o respeito pelo texto e o segundo a crítica ao mesmo, e o desmistifica baseado na posição hermenêutica do intérprete (TREITLER, 1990, p. 317).

\footnotetext{
10 Refiro-me aqui à diferenciação entre as duas abordagens feita por Goehr em Writing music history (GOEHR, 1992, p. 193-194). As características históricas são aquelas da categoria de elementos essencialmente musicais, as históricas são as das categorias extra-musicais e a das não musicais.
} 
A notação musical dentro do movimento da performance histórica é também necessariamente compreendida dentro de seu contexto, uma vez que as mesmas apresentam muitas lacunas. Essa concepção foi ampliada pelos trabalhos de Barthold Kuijken e Anne Smith. O primeiro trata de práticas musicais dos séculos XVII e XVIII e tem o sugestivo título Notation is not the music, o segundo aborda a música do século XVI e foi entitulado The performance of 16th century music: learning from the theorists.

Ambos trabalhos citados acima, estimulados pela atuação dos dois autores como intérpretes e professores de flautas antigas, trazem uma nova contribuição ao estudo da música desses dois séculos. Segundo esses autores, tanto a performance quanto a compreensão da notação desses dois períodos necessita um aprofundamento sobre a maneira como a música era compreendida nesses séculos. Como visto anteriormente, o lugar da música dentro das sociedades e a própria concepção dos músicos sobre o papel da música dentro das sociedades influenciam as práticas musicais e a própria expectativa acerca das habilidades esperadas de um músico profissional. As lacunas existentes nas partituras dos séculos XVI, XVII e XVIII deveriam ser preenchidas com base nessas habilidades, como a realização do baixo contínuo e ornamentação, que eram conhecidas por aqueles envolvidos na práticas musicais, mas muitas vezes não eram registradas objetivamente nos tratados.

Dentro das novas perspectivas de pesquisa musicológica, a pesquisa realizada em música renascentista deve ser realizada a partir do texto musical, sem desconsiderar fatores externos à música (BRETT, apud BENT, 1998, p. 16). O contexto musical deve servir para aumentar a nossa compreensão das peças e permitir que tenhamos condições de enxergar as principais características que podiam ser identificáveis pelos músicos da época.

Margaret Bent (1998, p. 17) propõe unir o contexto histórico à análise do texto musical por meio de uma análise historicamente informada. De maneira similar àquela como procedem os intérpretes historicamente informados, que buscam realizar as peças utilizando técnicas e instrumentos historicamente compatíveis com os utilizados na época em que as peças foram compostas, a análise proposta por Bent está fundamentada na teoria musical do período em que as peças foram compostas. Nas palavras da musicóloga:

Advogarei abordagens técnicas historicamente apropriadas para a análise de música antiga, fundamentada na teoria e no repertório musical correspondente, técnicas simples que precisam ser compreendidas e internalizadas em um nível gramatical antes que análises e interpretações válidas possam ser realizadas (BENT, 1998, p. 18-19). 
Apesar de ainda mantermos uma relação com as músicas desse período no presente por meio da performance histórica, nossa compreensão dessas peças está influenciada por concepções musicais contemporâneas. Ao demonstrar que um contato direto com o fazer musical do passado pode enriquecer a compreensão das composições do século XVI, a performance histórica pode inspirar as pesquisas musicológicas, enquanto estas alimentam intelectualmente as performances, em um diálogo benéfico para ambas. "Não só o destino é importante, mas também a jornada, não só o que mas o como, que coloca o destino em uma luz diferente" (BENT, 1998, p. 22).

A pesquisa acerca do tratado de escrito por Galilei não representa uma narrativa teleológica, como poderá ser constatado nos capítulos a seguir, a perspectiva essencialmente musical deixa lacunas impossíveis de serem preenchidas sem o contexto em que estão inseridas. As conclusões que serão alcançadas ao final não representam uma verdade irrefutável, mas uma interpretação de como os documentos históricos podem ser relacionados às músicas da época, para que se compreenda ambos com maior profundidade. Dessa forma, ambiciona-se contribuir com o diálogo que travamos com o fazer musical desse período.

\section{7 - Ferramentas para análise}

A presente pesquisa procura abordar as questões enfrentadas por músicos e musicólogos contemporâneos quanto à interpretação e análise das entabulações para alaúde do final do século XVI. Na pesquisa, utilizar-se-ão as técnicas de entabulação descritas por Galilei em seu tratado, juntamente com os preceitos teóricos que ele indica serem indispensáveis para a confecção das versões instrumentais, e, dessa forma, contribuir para o enriquecimento do processo de análise dessas peças. A comparação entre a técnica de entabulação e as teorias composicionais traz benefícios para a compreensão de características das duas, uma vez que a análise do processo de entabulação pode evidenciar práticas interpretativas não escritas, e o conhecimento das teorias composicionais da época pode esclarecer dúvidas em relação ao processo de criação das tablaturas.

A pesquisa será realizada com intuito de aumentar o repertório de ferramentas disponíveis para a compreensão das entabulações para alaúde. Utilizaremos como fonte principal o tratado Fronimo que descreve o processo utilizado por Galilei para criar as versões instrumentais e a forma como as teorias composicionais da época se relacionam a esse processo. A partir das descrições de Galilei, serão propostas algumas maneiras de analisar essas peças. Para atingir esse objetivo, será utilizado o método indutivo, uma vez que nesse método o pesquisador busca observações 
particulares para delas retirar generalizações que podem ser aplicadas a outros casos. Segundo Célia Regina Diniz e Iolanda Barbosa da Silva esse método está baseado em duas premissas: 1) causas iguais em circunstâncias iguais produzirão sempre o mesmo efeito; 2) a verdade observada nas situações investigadas também se aplica universalmente para as situações similares.

Diniz e Silva (2008, p. 4) afirmam que a utilização desse método nas ciências sociais pode ser problemática, já que cada expressão da cultura humana possui suas próprias idiossincrasias e nem sempre compartilham universalidades. Deve-se dar bastante atenção a esse alerta na realização de pesquisas em musicologia histórica, porque, ao se tratar da música de séculos passados, não se pode afirmar com certeza o quão difundidas eram as práticas descritas nos tratados. Muitas vezes, parece não haver consenso entre os teóricos da época sobre quase nenhum tópico. Galilei, por exemplo, estava envolvido em uma querela acerca do uso das dissonâncias com seu antigo professor Gioseffo Zarlino. No entanto, nos parece possível perceber práticas musicais comuns, ainda que com fronteiras temporais e geográficas bem definidas. Harold Powers nos ajuda a encontrar essas características generalizáveis. Ele recomenda que “... acima de tudo, deve-se permitir que teóricos de outras culturas musicais, incluídos aqueles das ancestrais à nossa, falem com suas próprias vozes o máximo possível, e nós deveríamos fazer a cortesia de considerá-los advogados em vez de testemunhas" (POWERS apud BENT, 1998, p. 53-54). Isso, porque, segundo Margaret Bent (1998, p. 21), existem características comuns que perpassam grande parte dos tratados teóricos do século XVI, mas também encontramos nos tratados algumas afirmações que parecem ser ideias de um único teórico. Assim sendo, devemos, de alguma forma, buscar as recorrências nos tratados e afastar os aspectos idiossincráticos. Bent (1998, p. 21) afirma que, além da comparação com as características comuns a outras teorias, as ideias apresentadas pelos teóricos devem ser corroboradas pelas obras do período.

Bent procura combinar o método histórico e o teórico analítico, o que permite que tenhamos uma compreensão cultural e histórica do texto musical e, ao mesmo tempo, explicita as técnicas que foram utilizadas em sua criação, o que, por sua vez, oferece subsídios para a performance. Bent resume sua proposição da seguinte forma:

Defendo abordagens técnicas historicamente apropriadas para a análise de música antiga, fundada na teoria e no repertório musical correspondente, técnicas simples que precisam ser assimiladas e internalizadas em um nível gramatical antes que atividades analíticas e interpretativas posteriores possam acontecer (BENT, 1998, p. 18-19). 
Os trabalhos de Margaret Bent são uma contribuição metodológica importante para a análise histórica de peças do século XIV e XV e serão esses trabalhos as principais fontes metodológicas para a pesquisa, por apontarem caminhos para unir a metodologia histórica e analítica.

Para realizar as análises propostas, Margaret Bent afirma que a contribuição da historiografia para a análise é ajudar o pesquisador a definir quais as ferramentas apropriadas para esse processo. A análise, por sua vez, traz para o centro da pesquisa de musicologia histórica o texto musical. Para isso, é necessário termos o conhecimento da gramática musical utilizada pelos compositores das peças. Em seu artigo, The grammar of early music (1998), ela demonstra como o conhecimento das teorias composicionais dos séculos XIV e XV resulta em análises mais precisas das peças. Esse mesmo princípio pode ser aplicado às análises dos processos de entabulação de Vincenzo Galilei.

Bent (1998, p. 29) faz analogias com as teorias linguísticas de Noam Chomsky, para ilustrar a necessidade do conhecimento ir além do que ela chama de gramatical. Os exemplos retirados de Chomsky mostram como frases com a mesma estrutura gramatical podem ter conteúdo semântico diferente. A comparação é feita com exemplos musicais onde a relação entre tenor e contratenor podem ser harmonizadas de maneiras diferentes. Isso demonstra, segundo a autora, como interpretações harmônicas modernas podem ser imprecisas. O que parecem tríades seriam na verdade díades com uma parte adicionada.

A análise de Bent leva à compreensão de que não basta conhecer o funcionamento gramatical da música do século XVI para analisar eficazmente as peças desse período. Como nos exemplos de Chomsky ${ }^{11}$ utilizados por Bent (1998, p. 21, 29-30), É necessário compreender como essas gramáticas eram utilizadas pelos músicos do século XVI, ou seja, qual o conteúdo semântico gerado por ela. "Claro que a teoria é insuficiente, como qualquer gramática ou cartilha relacionada à música ou literatura, mas é uma premissa necessária” (BENT, 1998, p. 35). É necessário, portanto, relacionar as teorias e composicionais e técnicas de entabulação à sua aplicação nas peças da época.

Bent (1998, p. 33-34) critica a forma como a análise do procedimento composicional precede a compreensão da gramática utilizada pelo compositor. Segundo a autora, Muitas das análises de músicas dos séculos XIV e XV não buscam compreender a perspectiva do compositor da obra e, sim, características das músicas de hoje dentro das obras. A existência dessas características não significa que elas sejam importantes para a compreensão da peça. Ela dá como exemplo a classificação do procedimento composicional como simultâneo ou sucessivo: o termo

${ }^{11} \mathrm{O}$ exemplo de Chomsky citado por Bent é "Flying planes is dangerous" e "Flying planes are dangerous". Nas duas frases, o termo "Flying planes" é escrito da mesma forma, mas possui um significado diferente em cada uma. 
composição sucessiva não é, segundo a autora, o mais adequado para definir o estilo de composição dos séculos XIV e XV. Ela prefere o termo diádica, por ele indicar que a estrutura das peças leva em consideração a relação entre tenor e cantus, as outras vozes são consideradas adições, da mesma forma que a música tonal é baseada em tríades e as demais notas são adições aos acordes.

Segundo a autora, um dos argumentos que levaram alguns musicólogos a deixar de lado os preceitos teóricos antigos foi o fato de na análise feita pelos mesmos a teoria parecia não representar o que acontecia na prática. No caso da música medieval, ela afirma que isso se dava pela má compreensão dos conceitos utilizados pelos teóricos e compositores da época (BENT, 1998, p. 35-38).

Cristle Collin Judd (1985) propõe, em Some problems of pre-baroque analysis, uma forma de analisar as obras dos períodos anteriores ao período barroco com três objetivos:

- alcançar uma compreensão histórica das obras;

- desenvolver ferramentas de análise baseadas nos preceitos teóricos de época;

- examinar o objeto musical e posicioná-lo em seu contexto histórico e estilístico;

Para chegar a esses objetivos, ela propõe o estudo de 5 principais características analíticas: texto, modo, articulação da estrutura, organização das alturas e da estrutura tonal. Dentro da teoria musical renascentista ela destaca quatro características como as mais importantes para o desenvolvimento das ferramentas analíticas: modo, contraponto, cadência e imitação. Nos capítulos anteriores, constata-se que o desenvolvimento dessas ferramentas de análise não se dá separadamente, ou seja, a análise de uma dessas características serve de respaldo para a das outras. Por exemplo, a análise do modo da peça é beneficiada pela análise dos pontos de imitação e das cadências, assim como a análise das cadências ajuda a compreender a estrutura contrapontística da peça.

A proposta desse trabalho é desenvolver uma forma de análise das tablaturas que permita ao músico e musicólogo contemporâneo um diálogo com as entabulações de peças vocais escritas durante o século XVI. Esse análise será desenvolvida a partir dos preceitos teóricos da época, tanto composicionais quanto de entabulação. O livro de Galilei servirá de guia, por ser o tratado de entabulação mais completo, principalmente com relação a conexão entre as teorias composicionais e a prática instrumental dos alaudistas. Nem todas as afirmações de Galilei poderão ser generalizadas, e o confronto com o repertório de entabulações servirá de critério para que exceções não sejam tratadas como regra. 


\section{CAPÍTULO 2 - PROCESSO DE ENTABULAÇÃO}

O estudo do processo de entabulação de uma peça vocal envolve a compreensão de diversas características acerca da sua feitura. Dessa forma, devemos investigar como os entabuladores realizavam a tradução de um sistema de notação para outro. Tal mudança de sistema requer a definição de como o âmbito da peça será realizado no instrumento, no caso de Galilei, essa relação se dá por meio das poste ${ }^{12}$, sistema que relaciona a afinação do alaúde às alturas presentes nas composições. Mais além, Galilei demonstra que para realizar as entabulações era necessário conhecer a teoria composicional da época, para que as mudanças na composição original, que sempre envolviam o processo de entabulação, não desrespeitassem as prescrições teóricas.

Philippe Canguilhem começa sua descrição do método de entabulação de Vincenzo Galilei com uma citação de Galilei que afirma que o trabalho de entabulação é uma tarefa que exige do músico ser bom cantor, inteligente contrapontista e teórico (CANGUILHEM, 2001, p. 45). Essa citação já apresenta um dos principais pontos trabalhados pelo musicólogo, o de que Galilei considera essencial o domínio da arte do contraponto para a realização de entabulações, que o diferenciará dos outros teóricos do assunto.

Com relação à transformação da partitura em tablatura, Canguilhem afirma que Galilei é extremamente discreto e para compreender seu método devemos comparar as características do processo de entabulação com outras fontes do século XVI (CANGUILHEM, 2001, p. 60). Na página 12 da edição de 1584, o próprio Galilei ressalta que seu processo de entabulação não será descrito explicitamente ao indicar que as regras devem ser deduzidas dos exemplos que ele coloca no livro. Para uma melhor compreensão do processo de mutação composicional, Canguilhem, Hiroyuki Minamino e Marie Louise Göllner comparam exemplos retirados de manuscritos com as descrições feitas por Adrian Le Roy e Galilei.

Segundo Canguilhem, Galilei considera que o principal objetivo de um entabulador deve ser representar com fidelidade o modelo vocal. Para manter-se fiel, Galilei afirma que o entabulador deve conhecer os tópicos da teoria musical da época. Canguilhem separa três tópicos trabalhados pelo alaudista no tratado: musica ficta, diminuições e respeito ao contraponto original. Pode-se acrescentar, a esses, outro tópico que também será importante para a análise das tablaturas e dos processos de entabulação: a definição da tessitura.

\footnotetext{
${ }^{12}$ As poste serão descritas no capítulo 2.4.
} 


\subsection{Estágios preliminares}

O estudo dos estágios preliminares do processo de entabulação trata de como os alaudistas compreendiam o processo de composição das peças vocais. Isso, porque a forma como os compositores compunham parece ser emulada pelos entabuladores. Podemos dividir os diferentes processos de entabulação em dois grupos, os que utilizavam a grade como estágio intermediário do processo de entabulação e os que entabulavam a peça diretamente a partir dos livros de partes ou livros corais.

Adrian Le Roy é um dos poucos alaudistas a detalhar o processo em um tratado de entabulação. Ao descrever o processo em seu tratado, A briefe and plaine instruction to set all musicke of eight divers tunes in tableture for the lute, publicado em 1574, ele afirma que as vozes devem ser entabuladas uma após a outra, partindo da mais aguda em direção a mais grave. Em sua descrição ele coloca as grades referentes a cada etapa do processo. No entanto, ele afirma que a confecção das grades é um trabalho desnecessário, mas reconhece que era o método utilizado por alguns alaudistas. Existem manuscritos que trazem evidências de que, alguns entabuladores, transcreviam a música para o formato de grade antes de entabulá-las, o que propicia uma compreensão mais profunda da estrutura vertical da peça.

Hiroyuki Minamino (1988, p. 40), em sua dissertação sobre os tratados de entabulação do século XVI, descreve o que poderia ser o processo de criação de uma tablatura a partir de peças vocais polifônicas. Ele sugere que a confecção de grades para auxiliar a criação das tablaturas seria uma prática comum, embora Adrian le Roy, ao descrever o seu processo de entabulação, não considere necessária essa etapa de preparação. Alguns manuscritos de Vincenzo Galilei possuem grades, o que Minamino toma como um indício de que Galilei tinha a prática de utilizá-las como estágio preliminar para a criação de tablaturas. Minamino aventa que os autores de tratados de entabulação utilizam as grades apenas para fins didáticos. Ainda que isso seja verdade, a utilização das grades, mesmo para fins didáticos, pode ser considerada uma evidência de concepção vertical das peças, enquanto a presença de descrições de entabulação separada das vozes pode evidenciar que a estrutura das peças ainda era concebida como sucessiva ${ }^{13}$.

Como citado acima, a descrição do método de entabulação utilizado por Le Roy: partir da voz mais aguda e seguir adicionando as vozes em direção à voz mais grave, parece demonstrar que ele compreendia as peças horizontalmente e que ele não se preocupava em visualizar a peça em uma

\footnotetext{
${ }^{13} \mathrm{O}$ processo de composição simultânea e sucessiva das vozes será descrito no capítulo 3.1 .
} 
versão completa antes de iniciar o processo. No entanto, Le Roy estava descrevendo um estágio intermediário de seu processo de entabulação. A transcrição da peça de um sistema notacional para o outro era seguida pela ornamentação da peça, e, somente após esse último processo, o trabalho era considerado terminado.

Para tornar essa peça perfeita, e mostrar, não só a simples e rude gramática, mas também aprofundar-se em algo como a eloquência da retórica, eu pensei que seria bom junto dessa primeira peça (para coroar o trabalho) adicionar um exemplo da mesma música ornamentada com pontos de corrida e passagens... ${ }^{14}$ (LE ROY, 1977, p. 13).

O tratado de Bartolomeo Lieto Panhormitano (? - 1558), Dialogo quarto di musica (1559), mostra de maneira similar ao de Le Roy uma peça entabulada voz a voz, partindo do cantus e chegando a entabulação completa com o baixo. Em Novum pratum musicum (1592), Emmanuel Adriansen (1554? - 1604) demonstra o processo de entabulação com a peça, Venga quel bel narciso, primeiramente notada em estilo similar ao de livros corais, em seguida uma espécie de etapa intermediária com as três vozes superpostas em tablatura, e, finalmente, a versão final ornamentada (fig. 2.1 $)^{15}$. Pode-se perceber, portanto, que esses três exemplos não utilizavam a grade como etapa intermediária. Coincidentemente, pelo menos dois dos casos citados, o produto final do processo eram peças bastante ornamentadas, o que não era o caso das entabulações feitas por Galilei.

Segundo Minamino (1988, p.83), algumas tablaturas presentes nos manuscritos de Uppsala são rascunhos e podem nos dar algumas evidências sobre esse processo de entabulação praticado no século XVI. Ele cita como exemplo a entabulação de Nul nest, na qual a tablatura e as partes estão em notação mensural e aparecem uma ao lado da outra. Minamino nos diz que o fato das vozes não estarem alinhadas ritmicamente sugere que elas não eram entabuladas acorde por acorde. Essa ideia é reforçada pela afirmação de Le Roy de que a entabulação de uma peça de polifonia vocal deve ser realizada voz por voz, seguindo-se a ordem das vozes da mais aguda para a mais grave. Esse processo era constantemente revisado pelo entabulador, uma vez que conflitos entre as posições em que se entabulam as vozes poderiam ocorrer. Portanto, ainda que as vozes fossem entabuladas individualmente, todas as vozes deveriam ser levadas em consideração simultaneamente para o processo ser dado por terminado.

\footnotetext{
${ }^{14}$ To make this woorke in all poinctes parfite, and to shewe you (as a man might saie) not onely the plaine and rude Grammer, but also further somewhat like the eloquence of Rhetorike, I have thought good in this place of the first Tune (to croune as it were the worke withall) to add an example of the same song, adorned with running poinctes and passages... (LE ROY, 1977, p. 13).

${ }^{15}$ As transcrições das tablaturas da figura 2.1 encontram-se no apêndice: figuras A.7 e A.8 na página 112.
} 
Ainda no manuscrito de Uppsala, encontramos algumas entabulações não terminadas que podem ser evidências de como o autor do manuscrito realizava o processo. Nelas, o cantus é sempre entabulado primeiro, fato evidenciado pelo fato de ele estar sempre completo, mas alto, tenor e baixo encontram-se parcialmente entabulados, seguindo a ordem descrita por Le Roy. Minamino (1988, p. 85) interpreta que o entabulador do manuscrito de Uppsala parece concordar com as indicações de Le Roy, salvo alguns exemplos, as entabulações parecem ter sido feitas da voz aguda para a mais grave. O musicólogo ressalta que esse método pode necessitar correções ao longo do processo, para que a duração das notas seja respeitada (MINAMINO, 1988, p. 87).

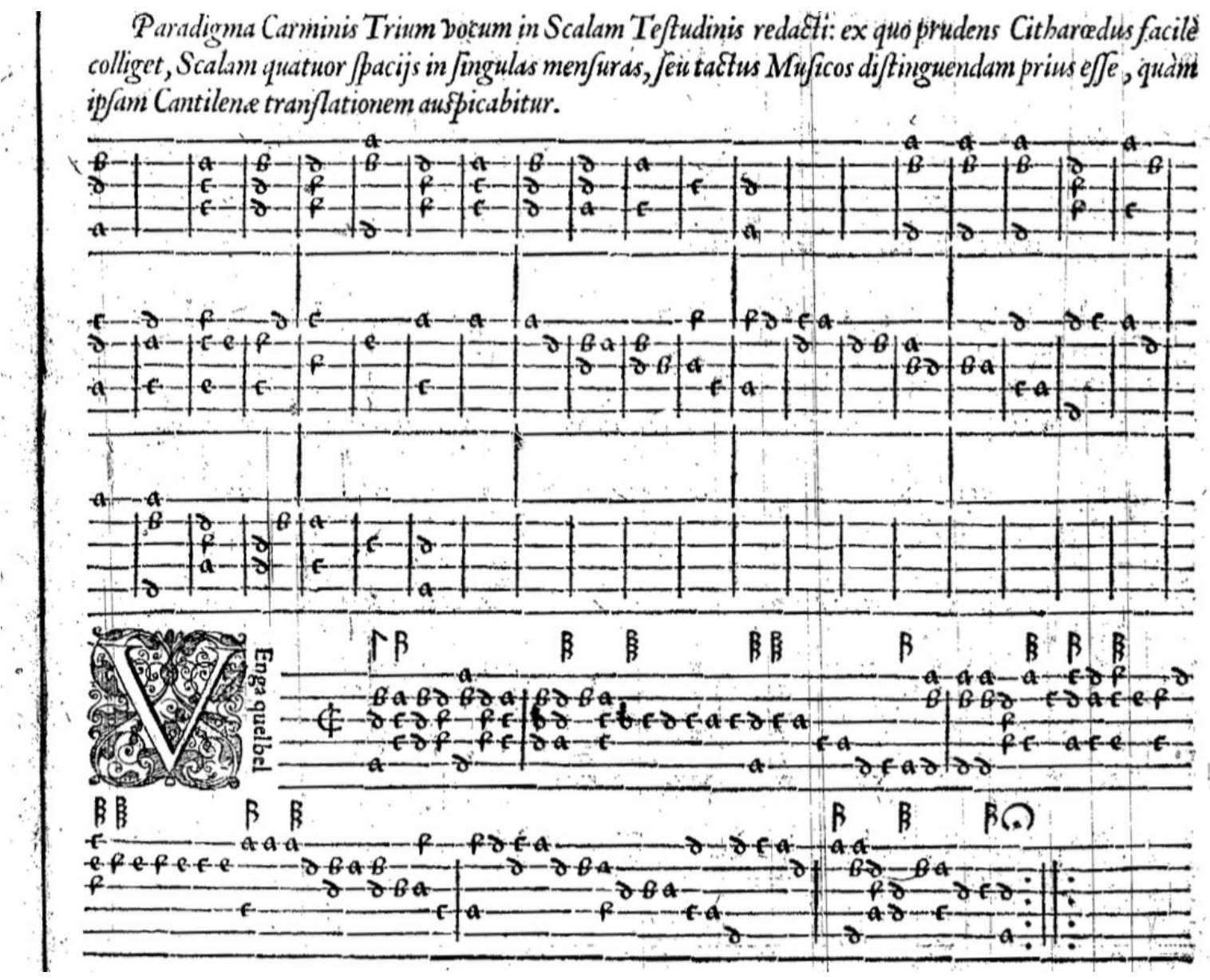

Fig. 2.1. Entabulação intermediária e ornamentada de Emmanuel Adriansen (ADRIANSEN, 1592)

Embora não seja uma prova irrefutável, a opção por um ou outro processo pode indicar como o entabulador compreendia o processo de composição das peças, ou até mesmo qual era o conhecimento de teoria musical esperado de um alaudista no século XVI. A descrição de Le Roy parece indicar que ele concebia as composições de forma sucessiva, uma vez que ele prescreve que a entabulação seja feita sucessivamente (voz por voz), ou que ele não esperava que os leitores de seu tratado possuíssem conhecimento de contraponto suficiente para que a visualização da grade 
fosse relevante. Alguns manuscritos, inclusive um do próprio Galilei, trazem peças copiadas em partituras com as vozes superpostas, como um estágio preliminar a realização da entabulação. Essa forma de trabalho pode ser considerada uma evidência de que os entabuladores tinham consciência do processo de composição simultânea, descrito por Bonnie Blackburn.

\subsubsection{Grade como estágio intermediário}

Canguilhem compara o tratado de Galilei com manuscritos que apresentam trabalhos de entabulação em estágio preparatório. No manuscrito 2986 da Bayerische Staatsbibliothek, existe a partitura de uma canção de Orlando de Lassus (1532 - 1594), Hélas quel jour, ao lado da transcrição em tablatura italiana (fig 2.2). Canguilhem supõe que, por não estarem superpostos como nos tratados de Galilei e de Le Roy, podemos inferir que o alaudista fez a partitura antes de realizar a entabulação (CANGUILHEM, 2001, p. 64). Ele ressalta que o fato de a entabulação não ser uma transcrição literal da versão escrita na grade também indica que o entabulador criou a grade antes de iniciar a entabulação. Embora isso não seja prova irrefutável de que o intuito do entabulador tenha sido fazer a partitura como um estágio preliminar ao processo de entabulação, nos parece plausível concluir que essa forma de organização das vozes auxiliou a tarefa, e Minamino (1988, p. 42) corrobora essa ideia. Esse mesmo fato também parece indicar que o entabulador, ao utilizar a grade como preparação para a realização da entabulação consegue refletir sobre a melhor forma de executar a polifonia no alaúde.

Pode-se verificar em outros manuscritos que outras técnicas eram utilizadas. Canguilhem aborda um manuscrito estudado por Göllner (1984) que apresenta as vozes superpostas, porém transcritas em tablatura (CANGUILHEM, 2001, p. 64). A pluralidade de técnicas não é estranha, já que no século XVI era comum que as formas de realizar uma mesma tarefa variassem regional e temporalmente. Esse forma de utilizar a grade já transcrita em tablatura é similar ao processo indicado por Adriansen, a diferença é que em seu a grade já está reduzida para uma pauta apenas.

Ainda que a expectativa de Galilei de que seu processo de entabulação fosse deduzido de seus exemplos resulte na inexistência de uma descrição textual de seu processo no tratado, Canguilhem busca indícios de seu método no manuscrito Ms. Gal. 9 da Biblioteca Nazionale Centrale de Florença (fig 2.3). Nele, existe uma partitura que dá indícios dos estágios preliminares do processo de entabulação de Galilei. Nesse manuscrito, apresentado por Edward Lowinsky em 1960, vários madrigais de Costanzo Porta (1528 - 1601) e Piero Vinci (1535 - 1584) foram copiados em partitura, mas com as vozes invertidas: as mais graves em cima, como nas tablaturas de alaúde 
italianas (CANGUILHEM, 2001, p. 64). Na figura 2.3, pode-se ver uma página do manuscrito citado retirada do artigo de Lowinsky. A qualidade da imagem não é boa, mas podemos ver no início do segundo sistema um bemol na quarta linha na armadura de clave da voz mas abaixo, o que corresponde à armadura com 1 bemol na clave $\mathrm{C} 1$.

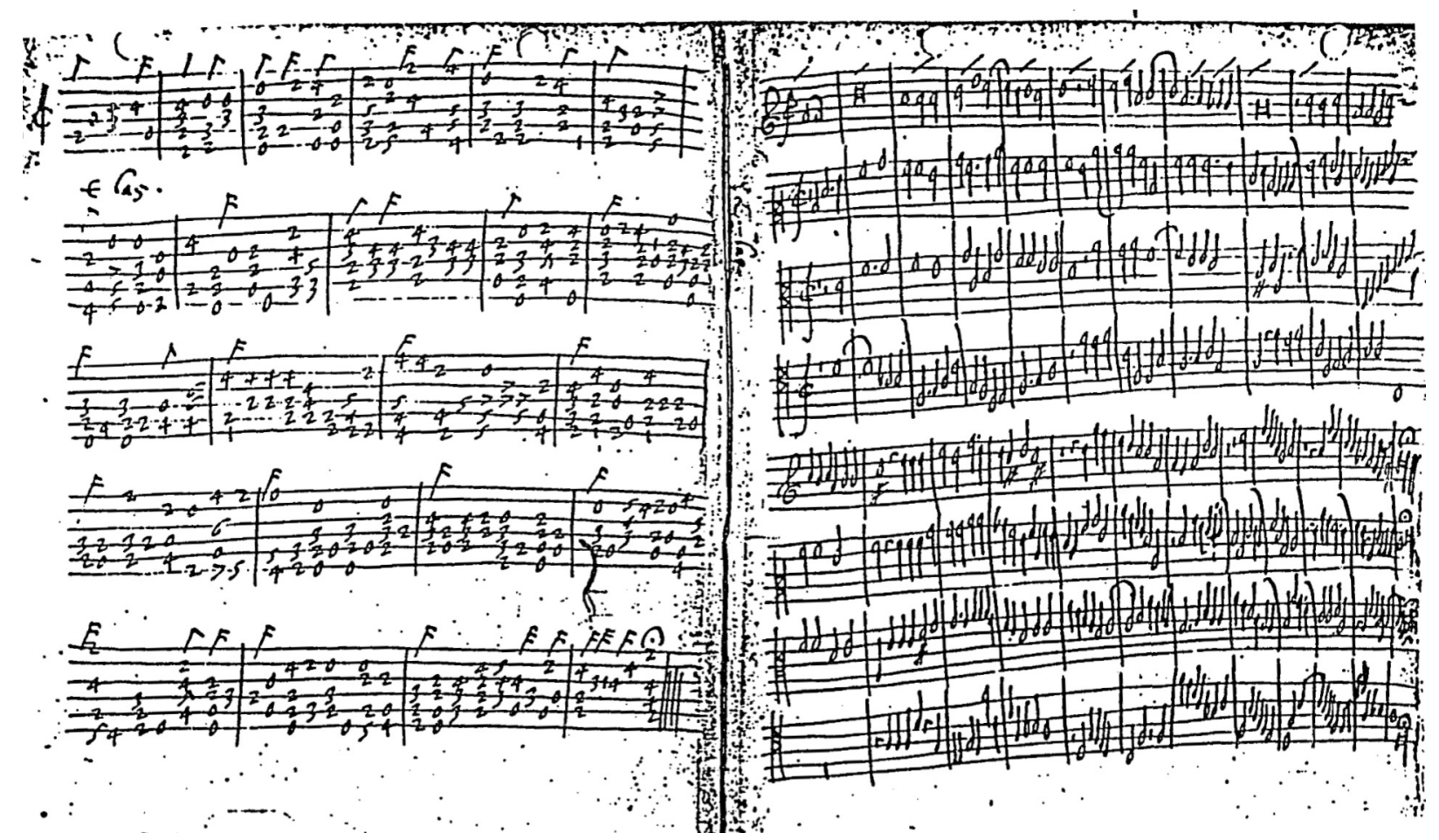

Figura 2.2 - Helas quel jour de Orlando de Lassus - entabulação e grade (Bayerische Staatsbibliothek de Munique, Ms. Mus 2986).

Como afirmado acima, é certo que eram múltiplos os processos de entabulação de polifonias vocais no século XVI. A análise do processo utilizado pelos entabuladores pode trazer indícios sobre a concepção deles das polifonias vocais e de como elas deveriam ser executadas no alaúde. Embora não se possa afirmar com certeza, parece que os entabuladores que apresentam versões finais bastante ornamentadas não utilizam a grade como estágio intermediário, possivelmente porque antes da entabulação estar pronta, ou seja, ornamentada, eles produzem uma versão sem ornamentos, já em tablatura, que auxilia na percepção de como as vozes soam juntas no alaúde e permite fazer ajustes que possibilitem a execução no instrumento. Enquanto que outros, como Galilei, primam pelo respeito ao contraponto original, o que, segundo o próprio Galilei, significa utilizar menos diminuições, utilizam a grade como recurso visual para criar as entabulações, possivelmente para ter uma compreensão mais profunda da estrutura polifônica. 


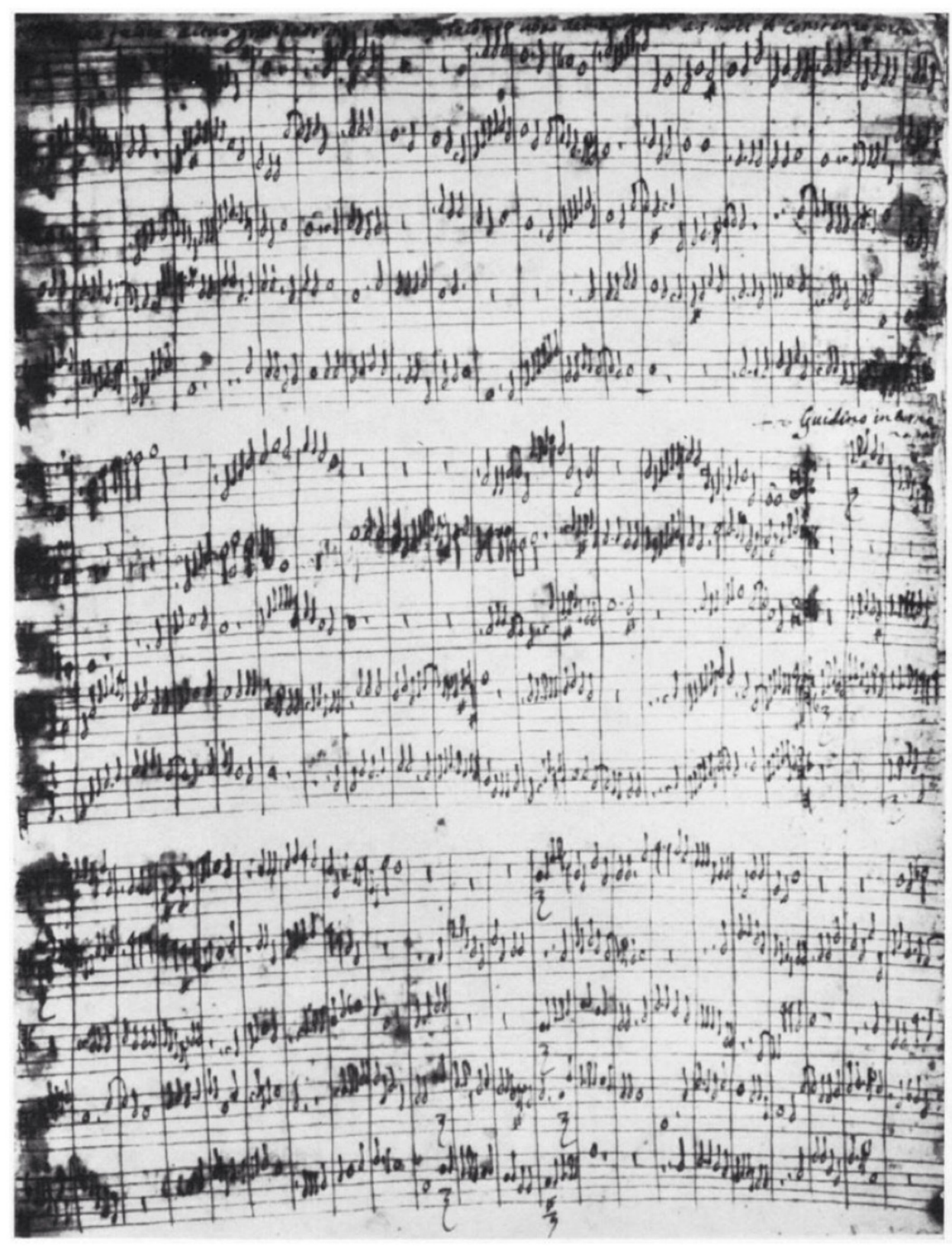

Figura 2.3 - Grade de Galilei com as vozes em posição invertida Ms. Gal. 9 Biblioteca Nazionale Centrale de Florença.

\subsection{Entabulação de peças com mais de quatro vozes}

A compreensão das técnicas e do processo de composição utilizado pelos compositores das peças vocais a serem entabuladas parecem ser determinantes para uma entabulação adequada. Ao realizar a transcrição, o entabulador depara-se com diversas dificuldades que surgem ao mudar o meio em que a peça será executada, logo ele necessitará fazer algumas alterações na composição original. 
É por meio do conhecimento das técnicas de composição que Galilei afirma que o entabulador poderá compreender as características essenciais das peças vocais. Na edição do Fronimo de 1584, Galilei dá exemplos de como adaptar uma peça com mais de quatro vozes para a tablatura, na qual todas as vozes não podem ser executadas simultaneamente no alaúde (GALILEI, 1584, p. 55). A indicação de qual voz pode ser retirada parece indicar que ele tinha uma concepção simultânea do processo composicional, relacionada à prática descrita por Blackburn.

Galilei utiliza como exemplo uma canção de Gianetto da Palestina a 5 vozes, Se tra quest 'herbe e fiore. Ele afirma que o objetivo de retirar algumas notas do contraponto é acrescentar graça e leveza à entabulação (GALILEI, 1584, p. 52). No entanto, Galilei indica que, em peças com até quatro vozes, todas as notas devem estar presentes. Para as que tem mais vozes, ele indica as seguintes regras:

- Podem ser retiradas algumas notas das vozes internas;

- Podem não ser entabuladas notas que fazem oitava com alguma das partes;

- Se houver uma terça e uma décima com a parte grave, deve preferir-se a décima;

- Também deve preferir-se a décima à quinta, principalmente quando aquela for maior por conta de algum acidente.

Na figura 2.4, podemos ver um exemplo do próprio Galilei de como suprimir uma voz na entabulação em obras com mais de quatro vozes. Na peça de Gianetto, Galilei exclui da entabulação a nota Si do segundo tempo do penúltimo compasso da segunda voz (fig. 2.5 e 2.6). A supressão dessa nota atende a todas as recomendações, já que a nota pertence a uma voz interna e faz uma oitava com a voz do baixo. As outras notas que estão oitavadas são o Ré do tenor e do cantus, no entanto as vozes do cantus, que não é voz interna, e tenor fazem uma décima e uma terça com o baixo, intervalos que Galilei dizia serem importantes. Mais além, a nota do tenor é uma semibreve que foi atacada no primeiro tempo do compasso, portanto não é atacada pelo instrumentista no segundo tempo. No entanto, o acorde seguinte gera uma dúvida em relação ao critério de Galilei para supressão de notas, uma vez que da maneira como ele está entabulado sua execução é muito difícil. 


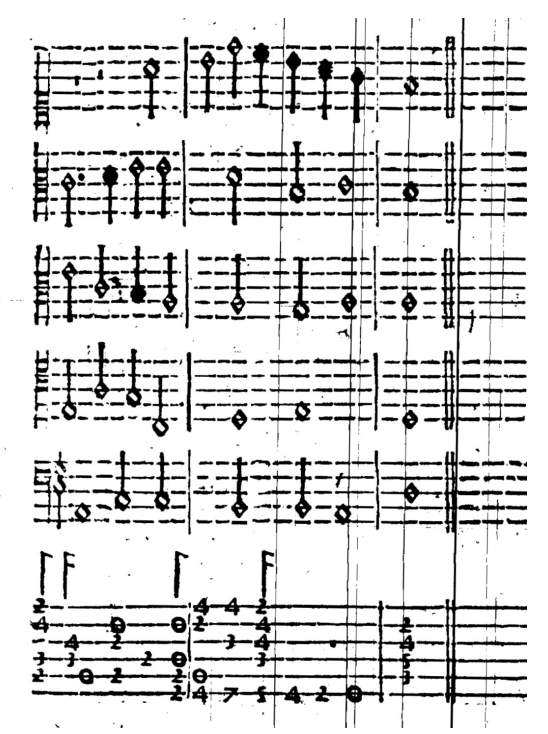

Figura 2.4 - Exemplo de supressão de uma voz na entabulação (GALILEI, 1584, p. 54).

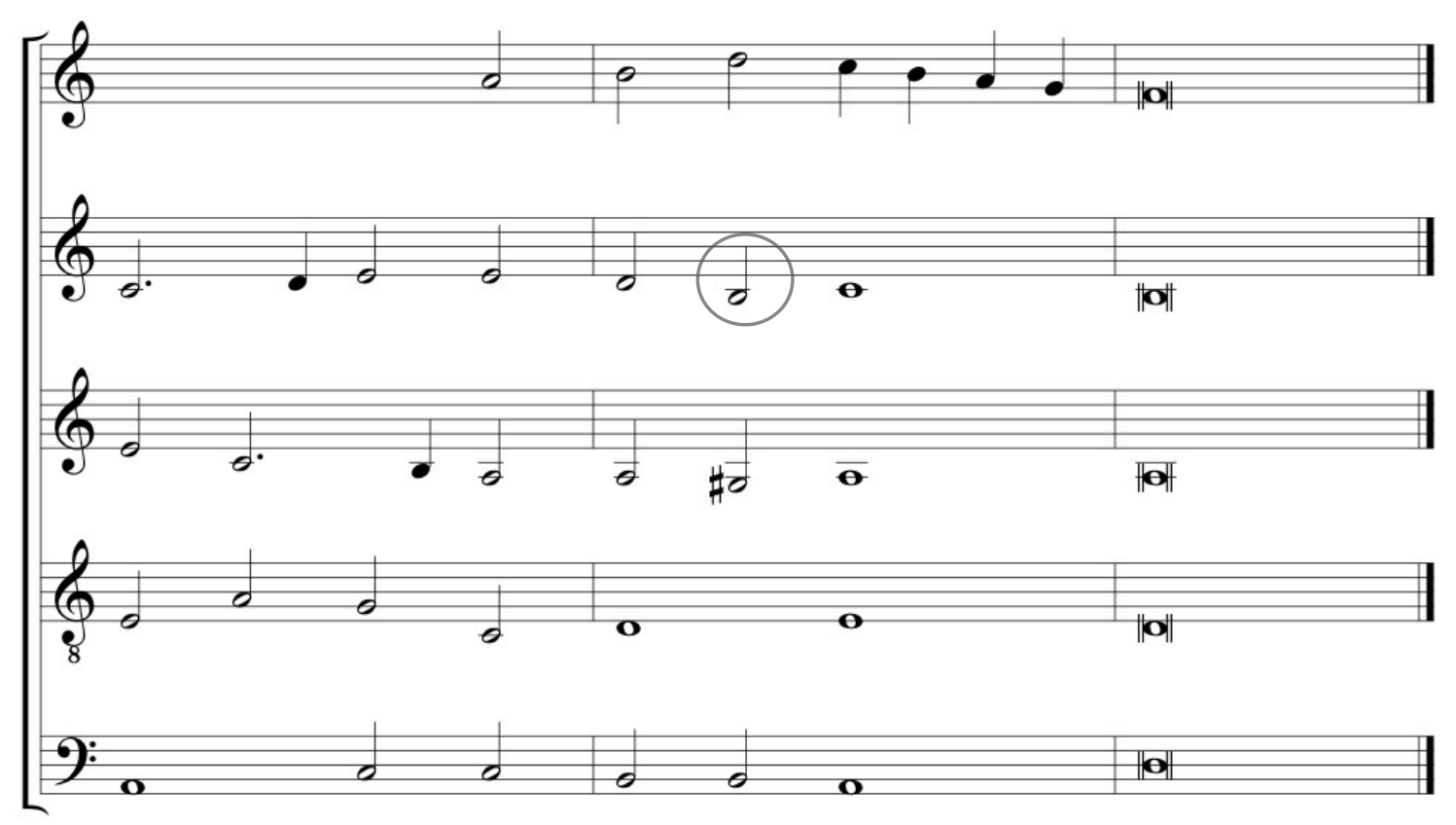

Fig. 2.5. Exemplo de supressão de nota transcrição da grade original.

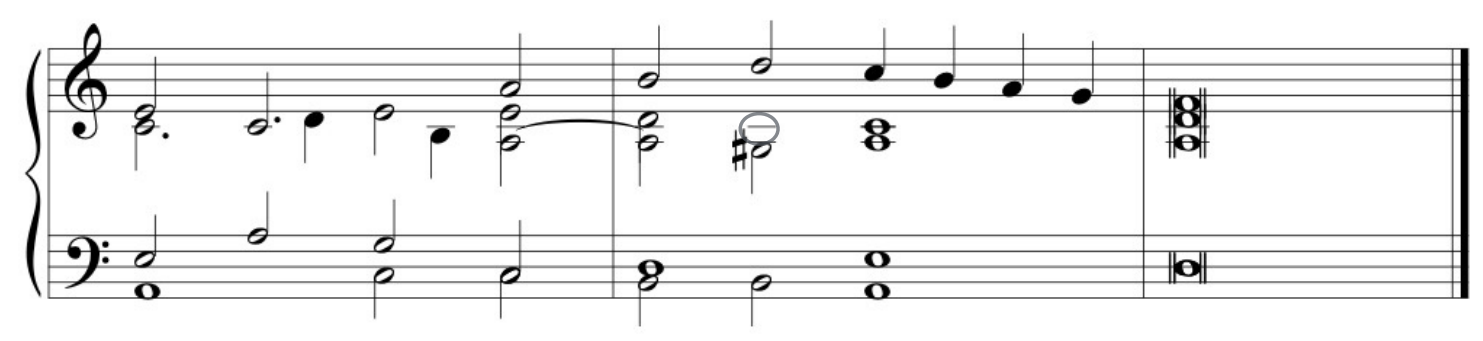

Fig. 2.6. - Exemplo de supressão de nota transcrição da tablatura. 


\subsection{Alterações ao contraponto original}

Minamino (1988, p. 89-97) afirma que, quando inevitável, alterações eram feitas ao contraponto original. Ele enumera as principais:

- divisão das ordens;

• omissão;

- conceito de dualidade;

- adição;

- transposição;

- troca de vozes;

- mudança de notas;

- uso de cordas oitavadas.

Pode-se separar essas alterações em dois tipos: as que de fato alteram a textura contrapontística original, que mudam significativamente o que havia sido determinado pelo compositor e devem ser sempre realizadas sem desrespeitar as regras de contraponto; e as que representam apenas uma técnica pouco usual de execução.

Nesse último tipo podemos incluir divisão de ordens, uso de cordas oitavadas e conceito de dualidade. Essa última espécie de alteração consiste na utilização das cordas duplas do alaúde para tocar notas que de outra forma seriam muito difíceis e para executar uníssonos com apenas uma nota, Galilei, no entanto, recomenda que sempre que possível os uníssonos sejam executados utilizando duas notas (GALILEI, 1584, p. 108). A divisão das ordens foi uma prática pouco utilizada e apenas quatro fontes citam essa possibilidade: Vincenzo Capirola, Miguel Fuenllana, Juan Bermudo e Valentin Bakfark. Essa técnica consiste em prender apenas uma das cordas das ordens duplas com o dedo, dessa forma pode-se executar uma nota a mais. No entanto, é uma técnica difícil de ser executada e com pequeno número de ocorrências no repertório. Outra técnica que utiliza as cordas duplas do instrumento é aquela que usa as cordas oitavadas. Essa técnica consiste em realizar, nas cordas mais graves, notas que normalmente seriam realizadas nas cordas mais agudas do instrumento aproveitando as oitavas que acompanham essas ordens graves (MINAMINO, 1988, p. 96).

As alterações que mudam a estrutura do contraponto podem ser evidências de que havia uma compreensão vertical das peças, ao menos por parte dos alaudistas. A transposição de notas 
significava, na maior parte dos casos, transportar uma nota impossível de ser tocada na oitava original para uma oitava mais aguda ou mais grave. A transposição de uma nota dentro da melodia pode significar que o entabulador julgava que aquela nota era importante para o resultado harmônico do trecho, uma vez que esse tipo de prática tinha efeito negativo na compreensão melódica da voz. Diferente, a troca de vozes consistia em mudar uma passagem inteira de uma voz para a região de outra voz. A adição de notas, por sua vez, também tinha como objetivo texturas mais complexas ou passagens com uma sonoridade mais idiomática para o instrumento.

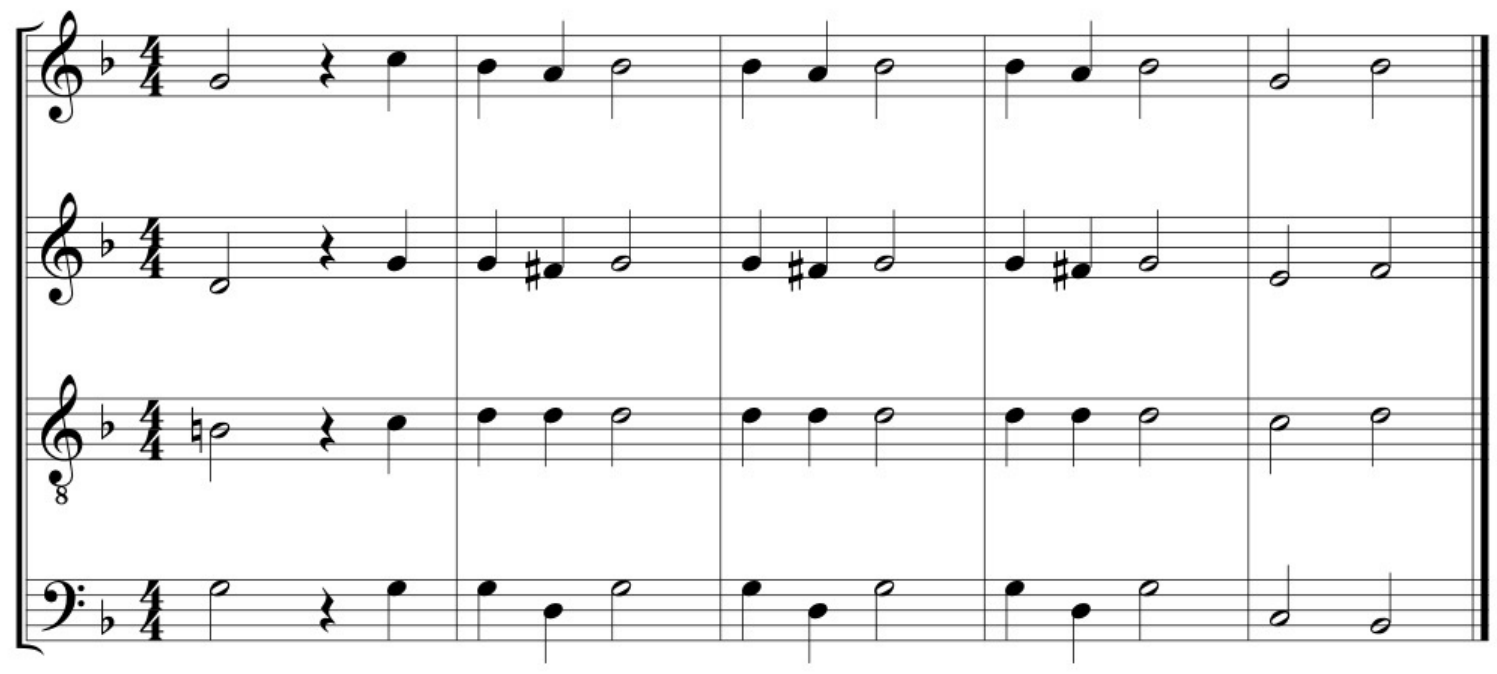

Figura 2.7. - Exemplo de transposição de nota para uma oitava mais aguda - grade original (MINAMINO, 1988, p. 326).

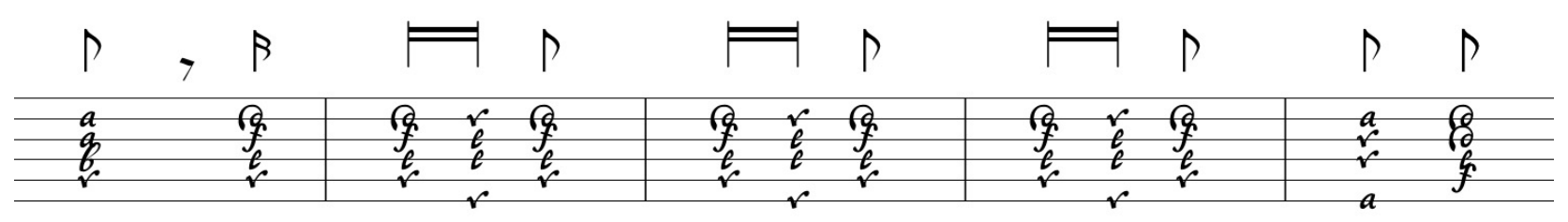

Figura 2.8. - Exemplo de transposição de nota para uma oitava mais aguda tablatura (MINAMINO, 1988, p. 326).

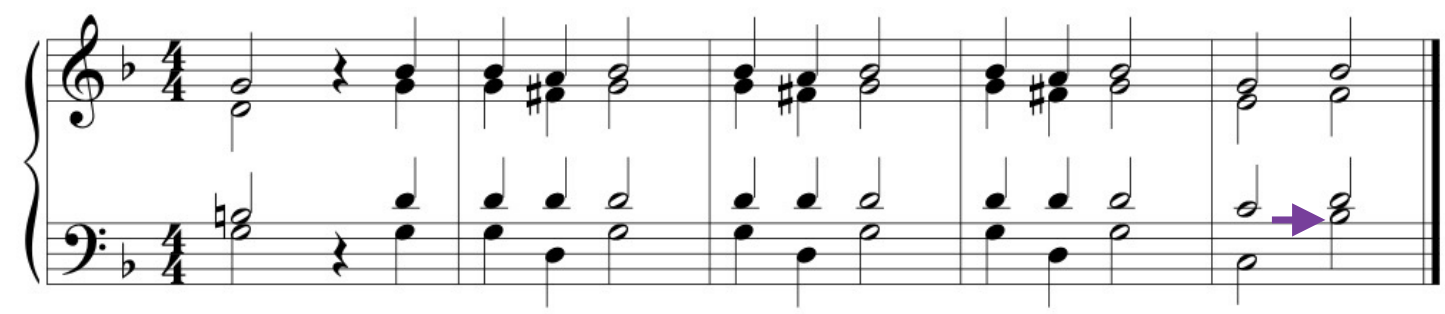

Figura 2.9. - Exemplo de transposição de nota para uma oitava mais aguda - transcrição da tablatura (MINAMINO, 1988, p. 326). 
A figura 2.8 é um exemplo de entabulação feita por Le Roy — Quand mon mary — em que a nota do último compasso é transposta uma oitava acima. Na figura 2.7, pode-se ver a composição original a quatro vozes, nela a última nota do baixo, um Sí bemol 1, é a última nota da clausula tenorizans $^{16}$ da cadência. É curioso perceber que a alteração, além de alterar uma das principais características da cadência, resulta em um salto melódico de sétima que é proscrito pelas regras de contraponto. Segundo Minamino (1988, p. 94), essa alteração acontece porque a nota é mais grave que a sexta corda do alaúde, no exemplo acima a sexta corda está afinada em Dó 2.

Além do contraponto, a estrutura rítmica da peça, às vezes, também precisava ser alteradas. As duas principais alterações que aconteciam eram a rearticulação de notas e o arpejo. Em relação a rearticulação de notas, Galilei afirma que devemos cuidar para que não sejam criadas dissonâncias indesejadas, mas elas devem ser usadas para evitar que o contraponto se torne pouco denso na execução ao alaúde. Segundo Minamino (1988, p. 100), o arpejo também era usado para diminuir o efeito da pouca sustentação do alaúde, por outro lado, a percepção do contraponto podia ser dificultada, mas essa técnica era bem aceita por Galilei. Minamino afirma que essa técnica pode ser uma das origens do style brisé do século XVII.

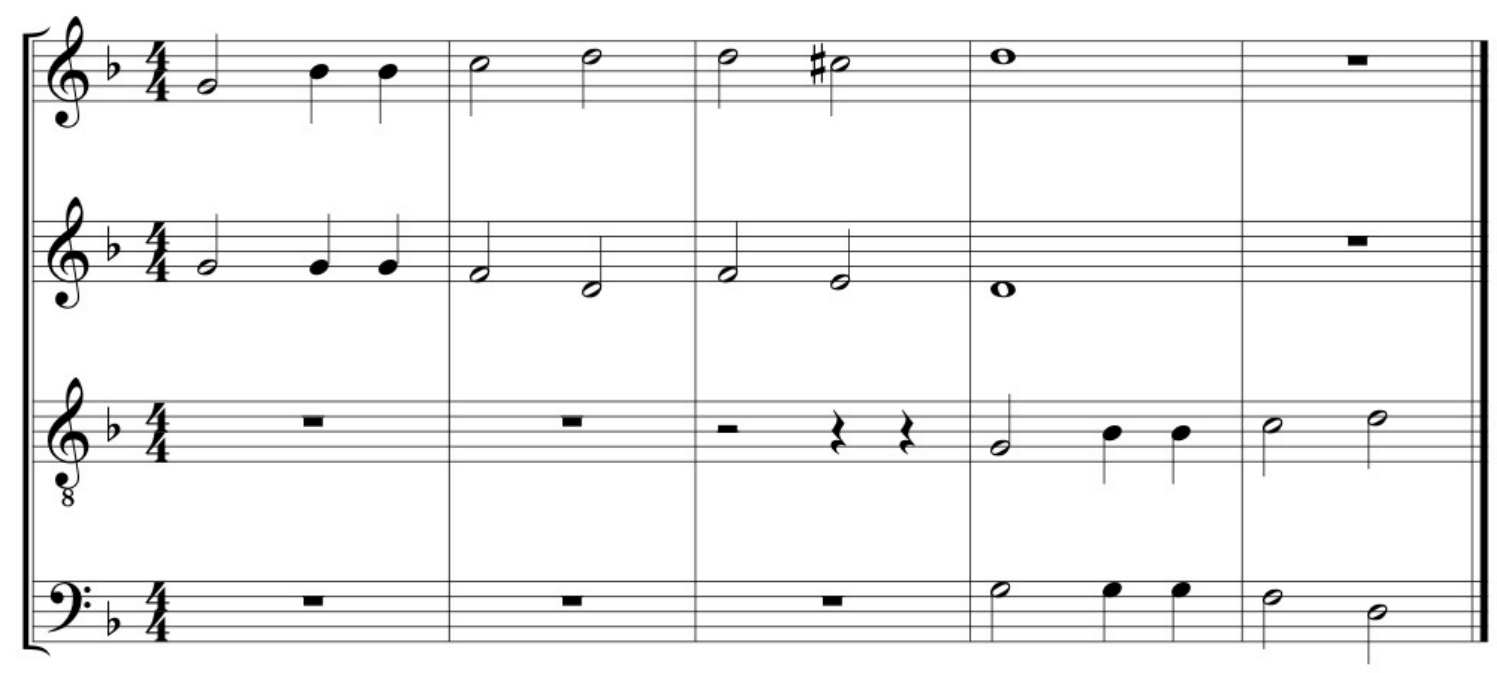

Figura 2.10. - Exemplo de arpejo em uma entabulação - grade (MINAMINO, 1988, p. 344).

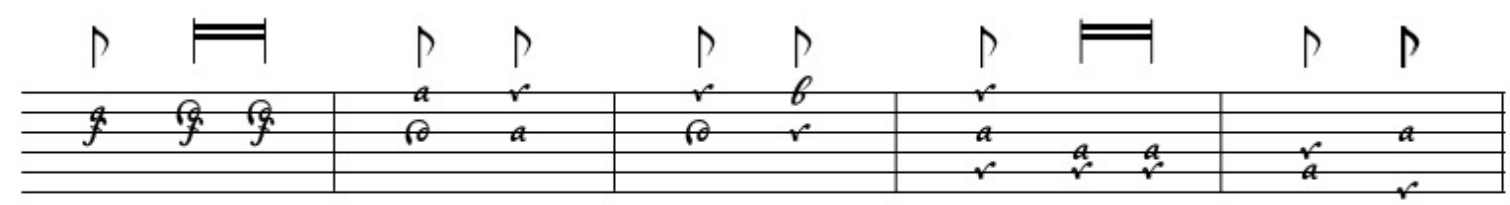

Figura 2.11. - Exemplo de arpejo em uma entabulação entabulação literal (MINAMINO, 1988, p. 344).

${ }^{16}$ As clausulas e as cadências serão discutidas no tópico 4.5 . 


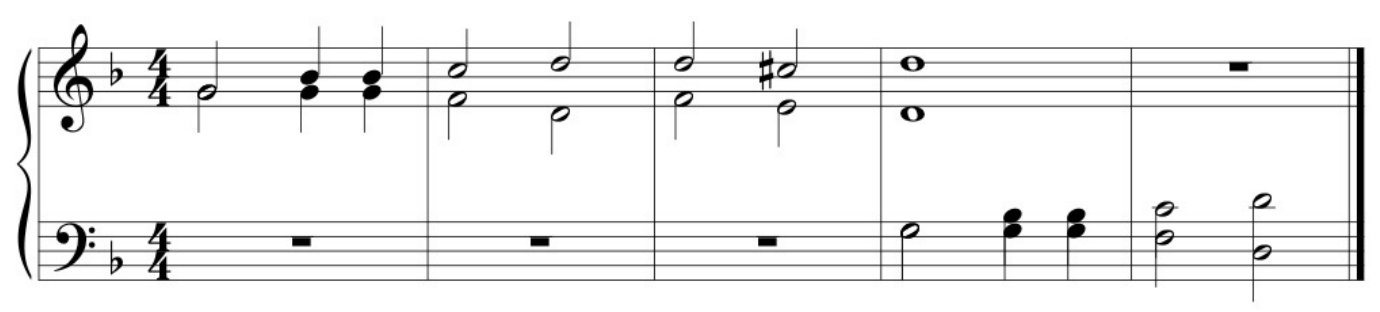

Figura 2.12. - Exemplo de arpejo em uma entabulação transcrição da entabulação literal (MINAMINO, 1988, p. 344).

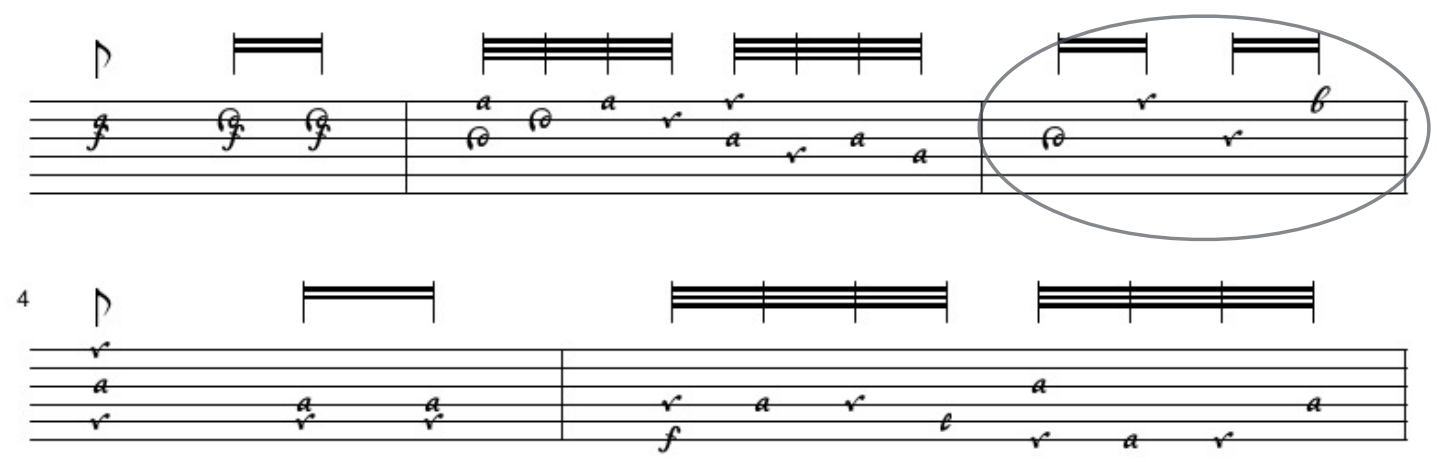

Figura 2.13. - Exemplo de arpejo em uma entabulação entabulação ornamentada (MINAMINO, 1988, p. 344).

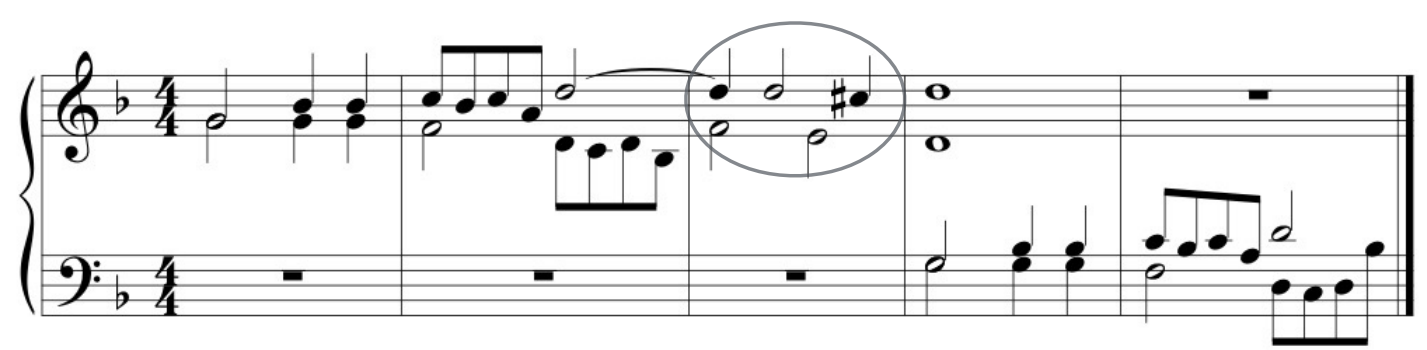

Figura 2.14. - Exemplo de arpejo em uma entabulação - transcrição da entabulação ornamentada. (MINAMINO, 1988, p. 344).

$\mathrm{Na}$ figura 2.13, pode-se ver um exemplo de entabulação em que a sequência de duas mínimas é substituída pelo que Minamino (1988, p. 100-101) considera um arpejo. Nesse exemplo, as recomendações de Galilei são atendidas plenamente. A cadência perfeita que existe no contraponto original é mantida, mas com alteração ela é acrescida da dissonância que acontece no terceiro tempo do terceiro compasso. Essa utilização da dissonância é típica do período e enriquece a textura contrapontística.

A questão que permeia o processo de entabulação é o quão literal deveria ser a tablatura resultante em relação ao original vocal. Se o entabulador estivesse preocupado com a possibilidade de execução da tablatura, haviam casos em que algumas adaptações precisavam ser feitas. Na maior parte das vezes, estas estavam relacionadas a duração das notas, seja porque o alaúde não sustenta 
as notas mais longas ou porque é necessário usar a corda para tocar outra nota. Minamino conclui que, mesmo às custas da facilidade ao tocar, as texturas contrapontísticas eram mantidas na maioria dos casos. Galilei (1584, p. 55) ressalva que, quando não é possível manter todas as notas audíveis por conta do grande número de vozes, deve-se manter aquelas que são as mais importantes, como foi visto na capítulo anterior. 


\subsection{As poste}

Podemos entender as poste como uma relação entre a afinação do alaúde e a amplitude que a obra a ser entabulada atingia. No Fronimo, elas aparecem em duas pautas. Na primeira, estão escritas as notas no sistema mensural, e, na segunda, estão escritas, em tablatura italiana, a posição, no alaúde, onde as notas da primeira pauta podem ser executadas (figura 2.16). Canguilhem (2001, p. 50) relata que um dos primeiros problemas dos entabuladores era passar de um sistema de alturas definidas (como a notação mensural) para um outro de alturas relativas (tablatura). Podemos considerar que as tablaturas de alaúde eram um sistema de alturas relativas, uma vez que existiam uma grande variedade de tamanhos de instrumentos, mais além, Hans Neusidler (1536) recomenda que o alaudista estique a primeira corda até quase o ponto de quebra e continue a afinar o restante das cordas a partir daí, essa prática demonstra como a altura real das cordas do alaúde podia variar mesmo em instrumentos do mesmo tamanho. $\mathrm{O}$ musicólogo parece afirmar que as poste mostram as possíveis afinações dos alaúdes, embora Galilei apresente as poste, em sua maioria, aos pares uma com bequadro e uma com bemol, o que não altera de fato a afinação do instrumento.

Com relação à afinação do instrumento, Galilei apresenta a que possui a corda mais grave afinada em Sol como a mais usada e mais fácil. Galilei (1584, p. 10) afirma que a afinação em Sol deve ser preferida sempre que for possível, no entanto ele ressalta que existem várias outras. No Fronimo, ele apresenta 8 afinações diferentes como pode ser visto no quadro 2.1 (p. 53). Galilei pouco fala sobre a seleção das poste. O provável motivo de ele ressaltar que as duas primeiras são as mais usadas é que elas contém todo o âmbito da Gamut (como pode ser visto no quadro de Hermann Finck (1527 - 1558) (fig. 2.15) esse âmbito era do Sol 1 ao Mi 4), principalmente se considerarmos a mudança de afinação que ele propõe no tratado.

Fro. Pode ser usada sua oitava que é a corda Tenore solta, mas advirto que são entabuladas apenas canções que tocam essa corda nas cadências, ou de passagem, porque utilizá-las naquelas que as frequentam, não seria um erro pequeno. Aqui nasce o que o excelente Francesco da Milano fez para escutar a nota $\mathrm{F}$ fa ut, quando entabulou a battaglia francese, ele afinou o primeiro $\mathrm{G}$ sol re ut no segundo trasto da corda baixo, para ter com comodidade nessa corda solta a supradita nota $\mathrm{F}$ fa ut. \& muitos outros que entabularam a [bataglia francese] na segunda posta mostram que afinaram o baixo, de forma que quando tocado 
solto soe uma oitava abaixo da tenore solto. Para acrescentar, portanto, graça e facilidade às canções, lhe bastará o exemplo da primeira canção que toca agora ${ }^{17}$. (GALILEI, 1584, p. 9)

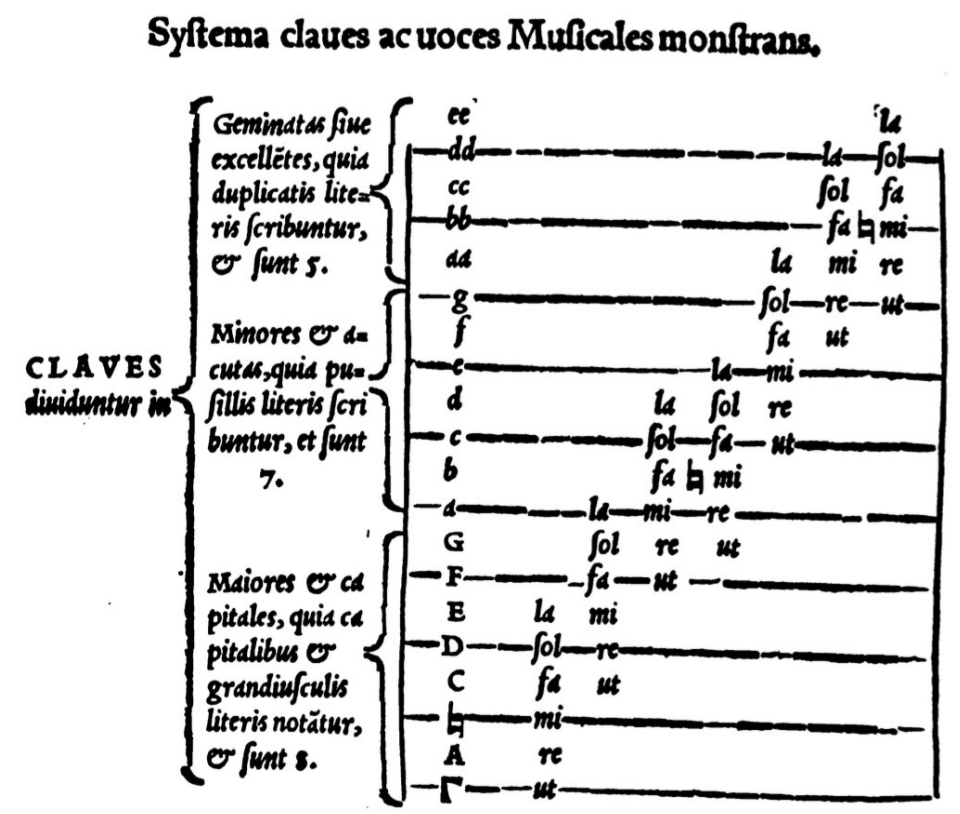

Fig. 2.15. - Quadro de Hermann Finck que mostra o âmbito da Gamut (FINCK, 1556, sig. Aiiii).

Com essa mudança de afinação, Galilei inclui no âmbito do alaúde o Fá 1, que, na segunda metade do século XVI, já era utilizada pelos compositores de música vocal. Percebe-se pelo texto de Galilei que a ideia de apresentar um grande número de poste é permitir que o entabulador escolha aquela mais adequada a cada projeto, ou seja, que permita que a entabulação seja bela e fácil. Canguilhem retoma o argumento de Minamino de que mais fácil significa a possibilidade de se usar mais cordas soltas, embora Galilei não explicite o que ele entende por mais fácil ${ }^{18}$. $\mathrm{O}$ musicólogo francês lembra a entabulação feita por Galilei de Vestiva i colli de Palestrina (1525 1594), nessa entabulação Galilei escolhe o alaúde em Ré, ainda que a nota mais grave da peça seja um Lá, o que possibilitaria o uso de um alaúde em Lá, mas com o alaúde em Ré há uma maior quantidade de notas que podem ser realizadas em cordas soltas. Segundo Canguilhem, o fato de Galilei afirmar que a escolha deve ser baseada na beleza e na facilidade técnica, é evidência de mais uma diferença entre a perspectiva de Galilei e a de Le Roy (CANGUILHEM, 2001, p. 52). De

\footnotetext{
${ }^{17} \mathrm{Si}$ sono serviti della sua ottava, che viene a vuoto nel Tenore: ma avvertite che non ci hanno intavolate se non quelle cantilene, che hanno tocco tal corda nelle cadenze, ò vero per transito: per che quando le havessero usate nel quelle che le frequentono, sarebbe stato non piccolo errore, \& di quivi nacque che l' Eccelente Francesco da Milano, quando intavolò la battaglia francese, per far sentire tal notta, fece venire il primo $\mathrm{G}$ sol re ut nel secondo tasto del Basso, per havere comodamente nel istessa corda a vuoto la sudetta $\mathrm{F}$ fa ut, \& molti altri che l'hanno intavolata nella seconda posta mostratavi, hanno acordata (per sonarla) di maniera il basso, che tocco a vuoto ha fatto ottava col tenore pur a vuoto. Per aggiuger poi gratia, \& facilità ale cantilene, vi basterà l'esempio della prima canzone che pur hora sonai.

18 Podemos considerar que esse conceito, muito subjetivo, provavelmente terá um significado diferente para cada alaudista.
} 
acordo com uma passagem retirada da página 36 do Les Instructions de Le Roy, este privilegiava a facilidade de execução como principal característica para escolha da posta, enquanto Galilei defende que se deve conciliar o âmbito da peça com a facilidade, mais um indício de que Galilei privilegiava o princípio do respeito ao contraponto original.

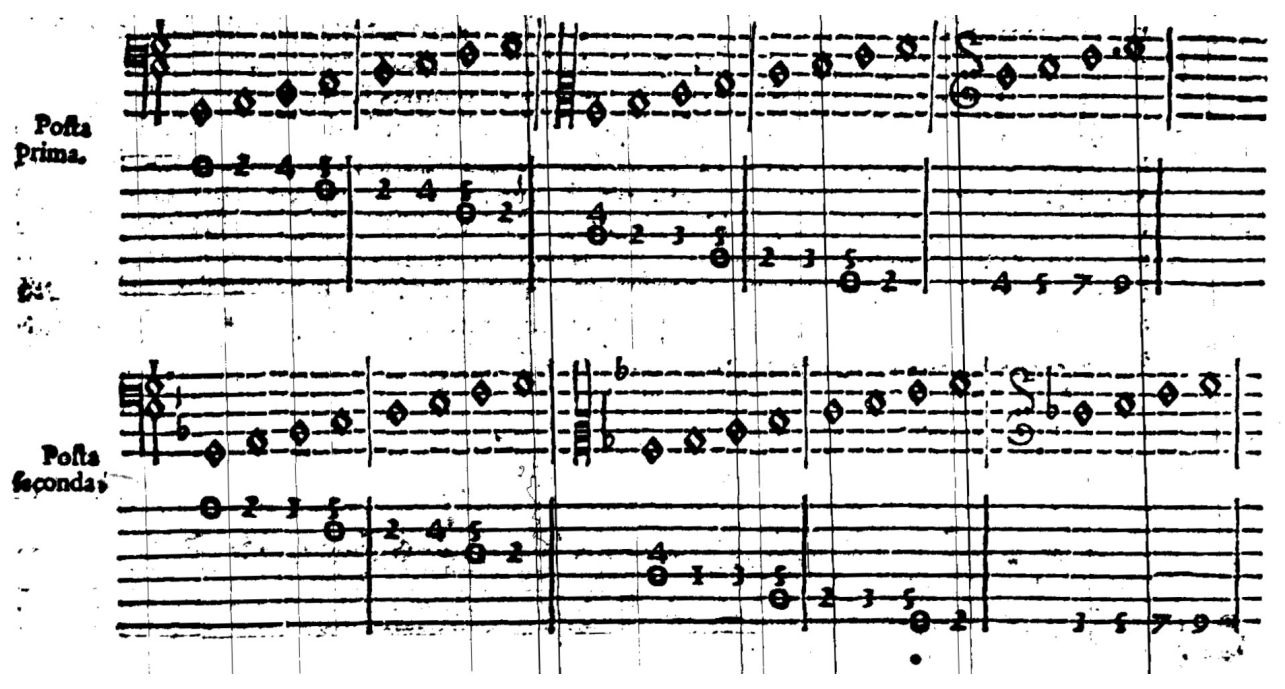

Figura 2.16. - Posta prima e posta seconda (GALILEI, 1584, p. 9).
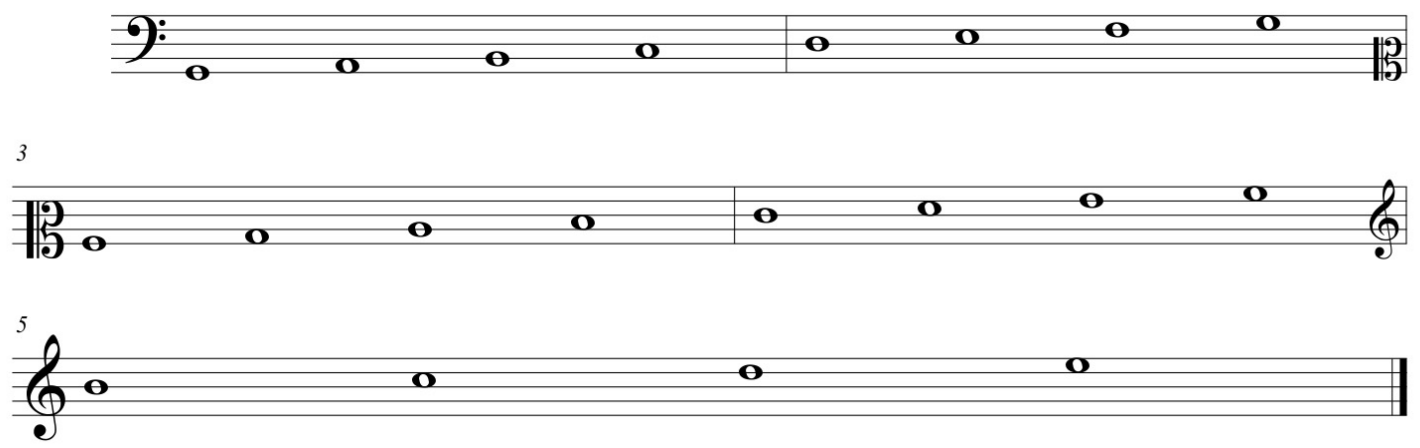

Fig. 2.17. - Transcrição da posta prima (GALILEI, 1584, p.9).
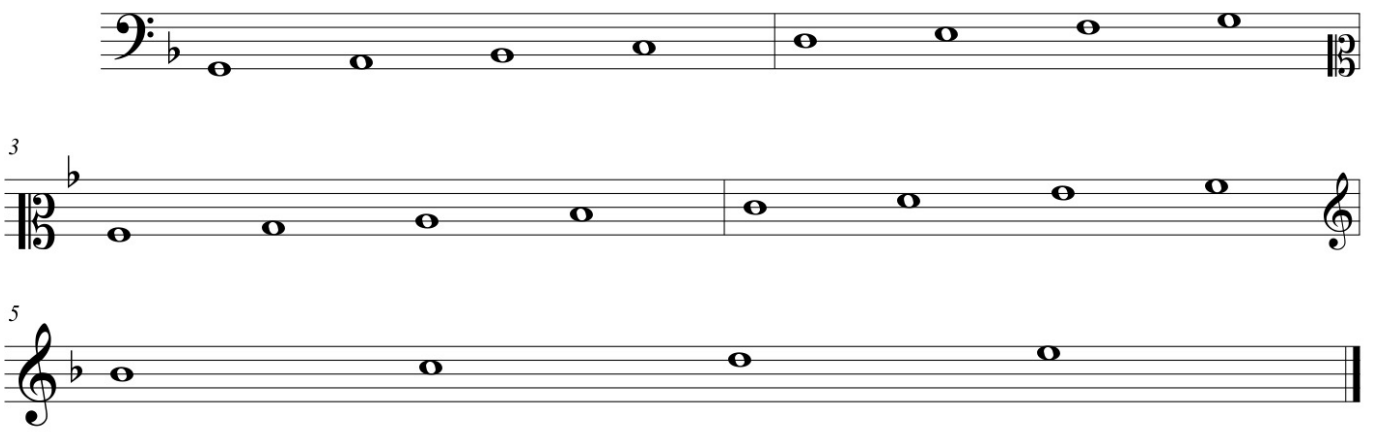

Fig. 2.18. - Transcrição da posta seconda (GALILEI, 1584, p. 9). 


\subsubsection{As poste e as claves}

Ao tratar das outras poste, Canguilhem ressalta o fato de que, na edição de 1568 , Galilei afirmava que o número a ser aprendido era de 10 poste, no entanto, em 1584, o número havia aumentado para 12. Ele lembra que Le Roy utiliza apenas 5 e boa parte dos alaudistas franceses utiliza apenas 7. Canguilhem conclui que o posicionamento de Galilei é ambíguo. Por um lado ele está próximo aos seus contemporâneos ao afirmar que o alaúde em sol é o mais recomendável, por outro ele parece preferir contemplar a totalidade das notas da versão original à facilidade de execução. Canguilhem afirma isso porque encontra no tratado de Le Roy momentos em que ele sacrifica notas graves do original para facilitar a execução da peça (CANGUILHEM, 2001, p. 58-59). No entanto, o fato de ele ter aumentado o número de exemplos de poste demonstra que, sem deixar de dar importância ao âmbito da peça ele ainda se preocupa com a possibilidade de execução da peça, uma vez que ele possibilita uma maior número de versões.

As relações entre a notação e a altura das notas, no século XVI, estava relacionada às claves utilizadas para notar a música. À época da publicação do Fronimo, dois sistemas de claves eram usados: chiavi naturalli e chiavi alte. Segundo Barbieri (1991, p. 11), desde o século XV praticavase a notação com diversos sistemas de claves, mas dentre os três principais (contrabaixo, natural e alta) não há registro na Itália do uso das de contrabaixo. Existem indícios de que o uso de claves altas estava associado a peças mais alegres e o de claves mais baixas a peças mais sérias. Jeffrey Kurtzman (1994, p. 644) cita uma passagem de Thomas Morley (1557 - 1602) que respalda essa teoria $^{19}$. Barbieri em seu artigo, no entanto, cita alguns De profundis que foram compostos usando claves baixas e outros com claves altas.

Galilei apresenta as poste utilizando vários conjuntos de claves, e parece ser mais interessante a comparação entre as claves utilizadas para notar as notas mais graves, uma vez que no costume da época não eram usadas linhas suplementares, assim Galilei ao registrar o âmbito inteiro das poste repetia as claves agudas, porque elas possibilitavam o registro das notas mais agudas. Ao notar as notas mais graves, no entanto, as claves coincidem com o uso feito delas na

\footnotetext{
19 “... mas você deve entender que aquelas canções compostas nas claves altas foram feitas para ter mais vida, as outras, em claves baixas, foram compostas com mais gravidade e sobriedade, se você cantá-las nas claves contrárias, elas perderão sua graça e serão de fato forçadas para fora de sua natureza. Tome um instrumento como um alaúde, orpharion, pandora ou outro similar em sua afinação normal e o afine uma nota ou duas mais baixo e ele se tornará mais pesado e sem clareza, sem o espírito que ele tinha antes, mais ainda se forem quatro notas abaixo da afinação natural.

Da mesma forma, tome uma voz muito boa e faça ela cantar acima do âmbito natural. Ela fará um som desagradável e doce ruído, desagradando tanto o cantor, por conta do esforço, e o ouvinte por causa do som selvagem" (MORLEY apud KURTZMAN, 1994, p. 644).
} 
prática vocal. As poste que são notadas usando o sistema de chiave alte possuem um âmbito equivalente ao seu uso nas peças vocais, como pode ser visto no quadro 2.1 .

Mais além, ao comparar o âmbito de cada posta com as claves utilizadas por Galilei pode-se inferir que ele aponta ao entabulador qual posta escolher com base nas claves e finalis usadas pelo compositor da peça vocal, embora sabe-se que em muitos casos a utilização de determinadas claves pressupunha que os músicos da época fizessem uma transposição para executá-la. A relação entre o modo das peças e a posta escolhida para a entabulação não parece ser direta, embora como a escolha da posta está relacionada ao âmbito e finalis da peça, que são características que ajudam a definir o modo de uma música, pode-se considerar que existe uma ligação indireta.

Wolfgang Freis afirma que a relação feita no tratado de Bermudo (1555) entre as claves e o braço do instrumento relacionava-se com a entabulação de peças vocais e com a representação dos modos (FREIS, 1995, p. 421). Segundo o mesmo autor essa prática proporcionava ao entabulador uma relação entre a altura das notas da peça vocal e os trastos da vihuela. Isso porque a vihuela como o alaúde utilizavam a tablatura, um sistema de alturas relativas. Segundo Freis, Bermudo reconhece em seu tratado duas formas de relacionar o âmbito das peças vocais com o âmbito do instrumento: fazer a música adaptar-se à vihuela; fazer a vihuela adaptar-se à música (FREIS, 1995, p. 424-425). Freis conclui que a posição das claves no braço da vihuela tinha dupla função, fornecer uma referência de alturas entre a peça vocal e afinação do instrumento e (de forma similar aos tipos tonais, tratados no capítulo 4.6) relacionar o sistema de claves utilizado com o modo da peça.

Pode-se concluir que Galilei tinha uma preocupação didática ao apresentar em seu tratado as doze poste. O grande número de alternativas, embora não seja exaustivo, como ele próprio afirma, permitiria ao aluno entabular quase qualquer peça vocal da época. Sua recomendação para a escolha de uma posta é de que todas as notas da peça possam ser tocadas com o mínimo de dificuldade (GALILEI,1584, p.12). Muito provavelmente, ele apresente as poste aos pares (uma com si bemol e outra com si bequadro) e com indicação do sistema de clave para facilitar a relação entre o sistema mensural e a tablatura para alaúde. A proposição de várias afinações de alaúdes diferentes e a relação com os sistemas de claves indica que Galilei se preocupava em entabular as peças em tessituras próximas das que elas eram cantadas e em respeitar as características do modo (tuono) da peça. O considerável número de poste é indício de que ele preferia adequar o alaúde à música, ainda que ele recomende que se utilize sempre que possível as duas primeiras poste. 


\begin{tabular}{|c|c|c|c|c|c|}
\hline Posta & Nota grave & Nota aguda & $\begin{array}{l}\text { Afinação do } \\
\text { alaúde }\end{array}$ & $\begin{array}{l}\text { Armadura } \\
\text { de clave }\end{array}$ & $\begin{array}{l}\text { Clave do } \\
\text { baixo }\end{array}$ \\
\hline 1 & Sol 1 & Mi 4 & Sol & Não & $\mathrm{F} 4$ \\
\hline 2 & Sol 1 & Mi 4 & Sol & Sim & $\mathrm{F} 4$ \\
\hline 3 & Dó 2 & Sol 4 & Lá & Não & $\mathrm{C} 4$ \\
\hline 4 & Sib 1 & Sol 4 & Lá & Sim & F3 \\
\hline 5 & Dó 2 & Sol 4 & Dó & Não & $\mathrm{C} 4$ \\
\hline 6 & Dó 2 & Sol 4 & Dó & Sim & F3 \\
\hline 7 & Ré 2 & Sol 4 & Ré & Não & $\mathrm{C} 4$ \\
\hline 8 & Ré 2 & Sol 4 & Ré & Sim & $\mathrm{C} 4$ \\
\hline 9 & Mi 1 & Dó 4 & $\mathrm{Mi}$ & Não & $\mathrm{F} 4$ \\
\hline 10 & Fá 1 & Ré 4 & Fá & Sim & F4 \\
\hline 11 & Dó 2 & Sol 4 & $\mathrm{Si}$ & Não & $\mathrm{C} 4$ \\
\hline 12 & Fá 1 & Sol 3 & Dó & Sim & $\mathrm{F} 4$ \\
\hline
\end{tabular}

Quadro 2.1 - As 12 poste de Galilei. 


\subsection{Musica ficta}

Margaret Bent afirma que o termo começou a ser utilizado no século XII para designar extensões falsas do sistema de hexacorde. A prescrição de musica ficta, que tem como base o sistema de solmização, surge na polifonia como resultado da alternância entre consonâncias perfeitas e imperfeitas, uma vez que deve chegar-se a uma consonância perfeita por meio de semitom em uma das vozes, o que era chamado de regra da proximidade. Bent diz que já no século XIV boa parte dos teóricos utilizava a ficta para solucionar problemas de contraponto (BENT, 2007, p. 5). Musica ficta não pode ser reduzida aos acidentes cromáticos, nem pode ser considerada uma influência direta do gênero cromático, uma vez que a maior parte das ocorrências são diatônicas.

Bent afirma que a mais completa compilação de regras retiradas dos tratados foi feita por Lowinsky em 1964, na introdução do livro, Musica Nova. Lowinsky divide as regras entre causa necessitatis e causa pulchritudinis. Ele considera que as seguintes são regras de necessidade (causa necessitatis): a proibição de se soar simultaneamente mi contra fa, uma nota sobre la sempre deve ser cantada como $\mathrm{fa}^{20}$ e a proibição de falsas relações. As que eram chamadas de causa pulchritudinis são a elevação dos sétimos graus em fórmulas cadenciais, a regra de proximidade e a regra de terminar as músicas em uma tríade completa (essa última no século XVI) (BENT, 2007, p. 10). Canguilhem acha interessante que Galilei não cita nenhuma das regras de causa necessitatis, mas de causa pulchritudinis, a regra da proximidade — deve-se chegar a uma consonância perfeita por meio da consonância imperfeita mais próxima - uma regra que exige conhecimentos teóricos e sobretudo de contraponto (CANGUILHEM, 2001, p. 65).

Fronimo é o único tratado de música instrumental que traz regras de como realizar musica ficta (GALILEI, 1584, p. 13-14). Canguilhem ressalta que a forma como Galilei aborda esse assunto é um indicativo de seus objetivos com o tratado, proporcionar ao instrumentistas uma forma de estudar teoria musical da época no alaúde. Para Galilei, conhecer as técnicas composicionais do período era essencial, uma vez que ele considerava responsabilidade do entabulador corrigir os erros do contraponto original. Galilei exige de seus alunos que eles comportem-se como contrapontistas e teóricos ${ }^{21}$ e afirma que é responsabilidade do entabulador realizar a ficta durante o

\footnotetext{
${ }^{20}$ Essas duas de acordo com as regras de solmização.

${ }^{21}$ Galilei, ao explicar a arte de entabular peças vocais, afirma que o entabulador deve ser "não só um bom cantor e contrapontista inteligente, como também um músico letrado, ou teórico como costumamos dizer" “... non solo d'essere buon cantore, \& ragionevol contrapuntista; ma di essere ancora ragionevol Musico, o Theorico che ci vogliamo dire" (GALILEI, 1584, p. 8).
} 
processo de confecção da tablatura, uma vez que ela raramente é realizada pelos compositores. Segundo Minamino (1988, p. 64), tablaturas oferecem uma ótima fonte para o estudo da musica ficta, pois são uma reprodução do que era tocado na época em relação as alturas. Seguem as regras para sua realização de acordo com o Fronimo:

- Todos os sétimos graus das escalas devem ser elevados nas cadências.

- Considerações verticais tem precedência sobre as horizontais, mesmo quando uma voz se move cromaticamente.

- Deve-se chegar às consonâncias perfeitas sempre pelas consonâncias imperfeitas mais próximas. (GALILEI, 1584, p.13)

- Oitavas aumentadas ou diminutas devem ser evitadas harmônica ou melodicamente.

- Nas imitações, devem se evitar as quintas diminutas, trítonos e oitavas diminutas e aumentadas. (GALILEI, 1584, p. 14)

A legitimidade de se utilizar as tablaturas para estudar musica ficta foi questionada por pesquisadores que consideravam que os objetivos dos entabuladores eram diferentes daqueles dos cantores, Minamino, no entanto, responde que elas são úteis, pois os mesmos preceitos teóricos eram compartilhados por alaudistas e cantores (MINAMINO, 1988, p. 69). Mas ele relativiza esse argumento ao afirmar que a utilização de musica ficta variava de região para região e apontando algumas diferenças entre a prática vocal e a instrumental. Galilei confirma que a utilização de ficta deve seguir as regras utilizadas para a música vocal. 


\subsection{Ornamentação}

Minamino (1988, p. 102) relaciona o conceito de decoratio da retórica aristotélica com ornamentação musical e afirma que esse é um exemplo de como a retórica influenciava a música estruturalmente. Segundo o autor, o fato de Le Roy afirmar que as entabulações literais que aparecem em seu tratado eram plaine and naked (simples e despojadas) leva à conclusão de que elas eram apenas esqueletos das peças que viriam a ser executadas. Essa forma de encarar a ornamentação, no entanto, não era unívoca entre os alaudistas do século XVI. Embora quase todos os alaudistas utilizassem ornamentação em suas execuções, alguns como Hans Neusidler (1508 1563) (1536) e Miguel de Fuenllana (1500 - 1579) (1554) acreditam que a ornamentação deve se restringir a algumas músicas e cadências.

Galilei afirma que as ornamentações, desde que utilizadas moderadamente, são imprescindíveis para uma entabulação. Nas pequenas polifonias, apenas uma voz deve ser ornamentada. Ao tratar de diminuições, Galilei, como a maior parte dos tratados de entabulação do século XVI, não aprofunda muito a questão. No entanto, ele ressalta que o princípio do respeito ao contraponto original deve ser observado (GALILEI, 1584, p. 29-30).

Alguns ornamentos utilizados pelos alaudistas ao entabular peças polifônicas alteram a estrutura contrapontística original, Minamino os chama de ornamentos estruturais (MINAMINO, 1988, p. 107). Um exemplo desse tipo de ornamento é o da figura 2.22. A figura 2.19 é uma parte de Si le bien de Jacob Arcadelt (1507 - 1568), uma grade criada por Minamino. No terceiro compasso a voz do tenor canta um Mi no início do compasso. Na versão ornamentada, Le Roy reduz a textura do contraponto de quatro vozes para duas. A diminuição criada por ele (figs. 2.22 e 2.23) une a voz do tenor a do alto e cantus, começa no Mi do tenor no compasso três e termina no Fá do cantus na metade do compasso 4 .

Jean-Michel Vaccaro demonstra, em La musique de luth en France au XVI siècle, como esses foram utilizados pelos alaudistas para criar versões em que sua intensão não era de reproduzir o modelo vocal o mais fielmente possível, mas de usá-lo como pretexto para uma criação ornamental original (VACCARO, 1981, p. 139). John Ward, em The use of borrowed material in 16th-century music, classifica as entabulações de música vocal em dois tipos: as que se aproximam de uma transcrição literal, e as que ele chama de glosa, em que a estrutura da peça é transformada pelo uso extensivo de diminuições (WARD, 1952, p. 91). Segundo John Ward, o uso de material musical de outros compositores não era incomum no século XVI, o que corrobora a ideia de que essa forma de entabulação resultaria quase em outra composição. Além das diferentes visões sobre 
as entabulações ${ }^{22}$, instrumentistas desse período utilizavam material musical retirado das polifonias vocais para criarem peças em gêneros musicais novos (WARD, 1952, p. 93-94). Em alguns casos são tantas as ornamentações que não se reconhece mais a peça original. Podemos considerar que essas recomposições são gêneros puramente instrumentais, como, por exemplo, as fantasias criadas por Galilei sobre duas entabulações presentes na primeira edição do Fronimo $^{23}$.

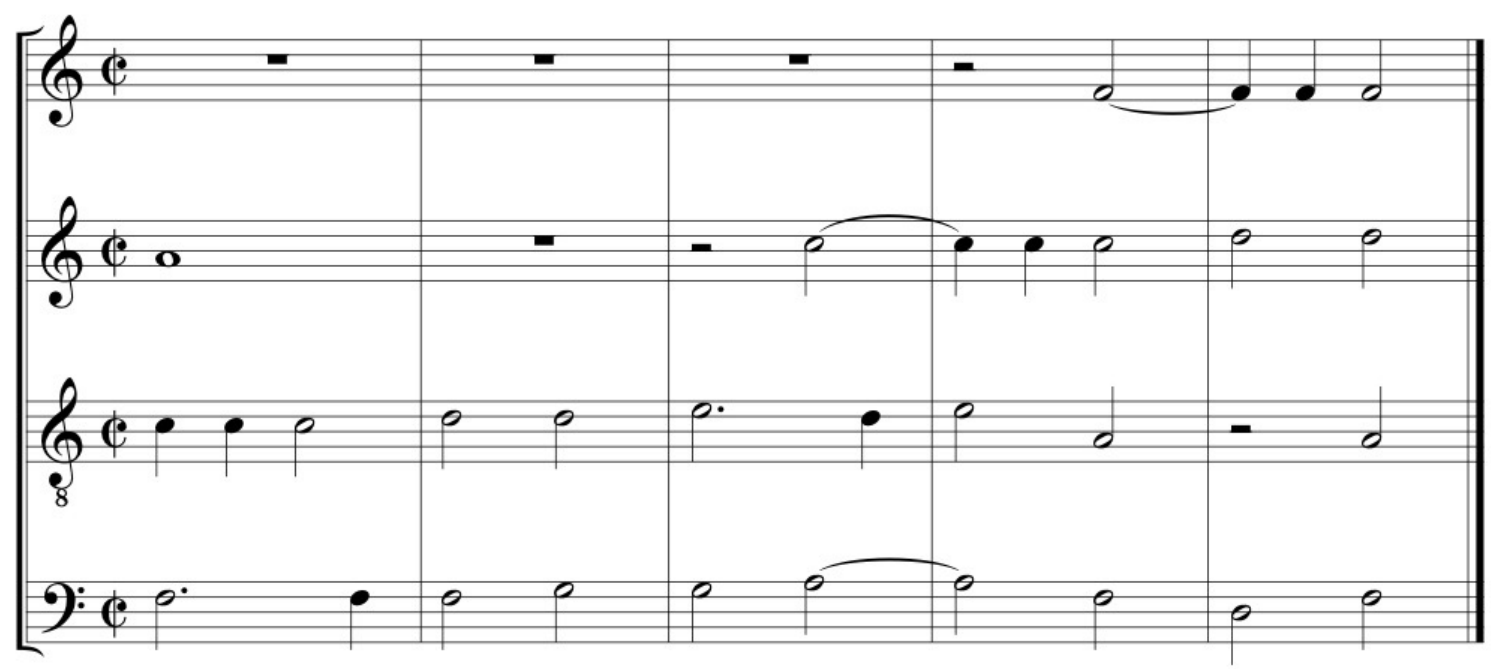

Fig. 2.19. - Exemplo de ornamentação que liga uma voz à outra - grade (MINAMINO, 1988, p. 356).

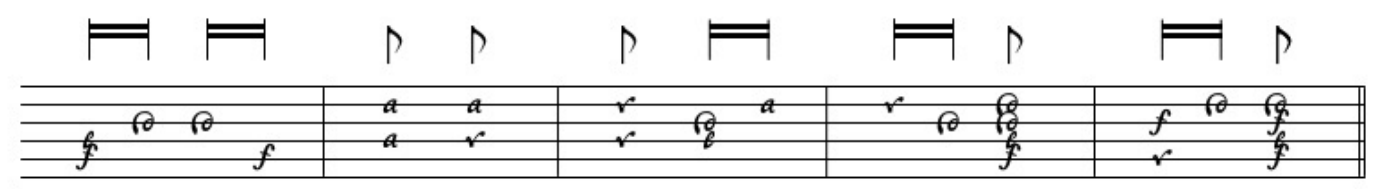

Fig. 2.20. - Exemplo de ornamentação que liga uma voz à outra entabulação (MINAMINO, 1988, p. 356).

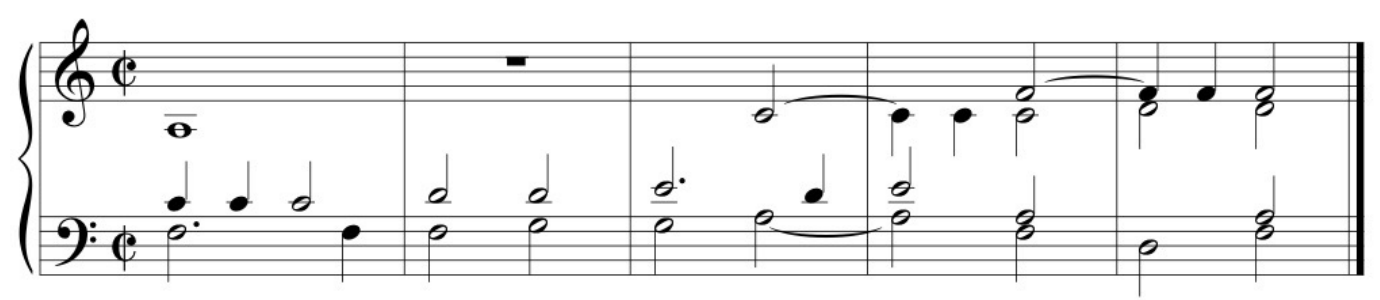

Fig. 2.21. - Exemplo de ornamentação que liga uma voz à outra transcrição da entabulação literal (MINAMINO, 1988, p. 356).

\footnotetext{
22 Ward (1952, p. 93) considera que as entabulações com um grande número de ornamentos estruturais seriam um novo gênero musical. Essa afirmação não parece encontrar respaldo nos tratados de Galilei e Le Roy, que, embora tivessem diferentes visões do que deveria ser uma entabulação de peça vocal, não consideram que a visão do outro seja uma forma musical diferente.

${ }^{23}$ São as fantasias criadas sobre Nasce la pena mia e sobre Anchor che col partire. A primeira foi analisada por Peter Argondizza e apresentada em 2013 na Renaissance society of america annual conference. A segunda foi analisada por Canguilhem (2001) no terceiro capítulo de seu livro acerca do Fronimo.
} 

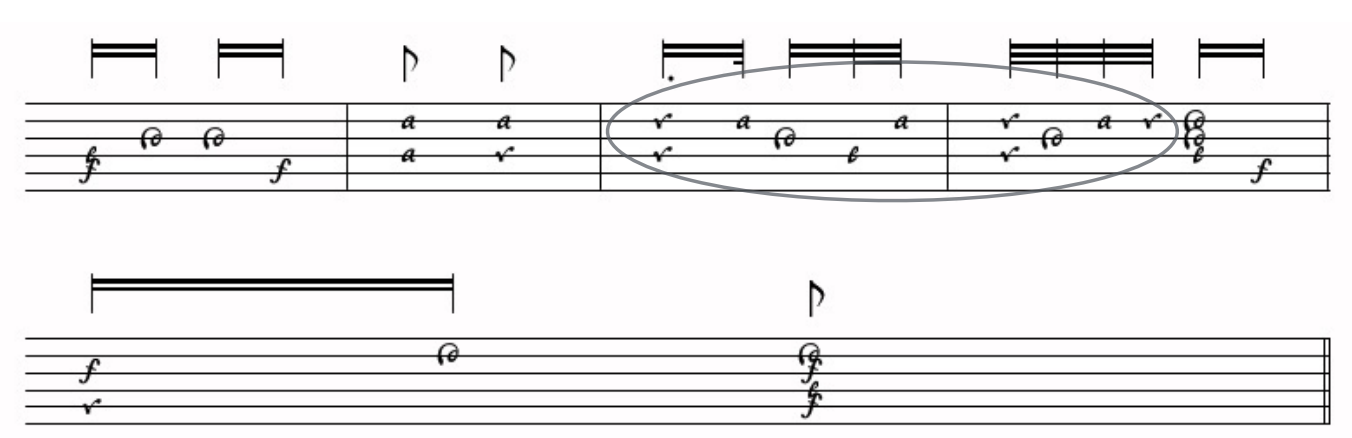

Fig. 2.22. - Exemplo de ornamentação que liga uma voz à outra entabulação ornamentada (MINAMINO, 1988, p. 356).

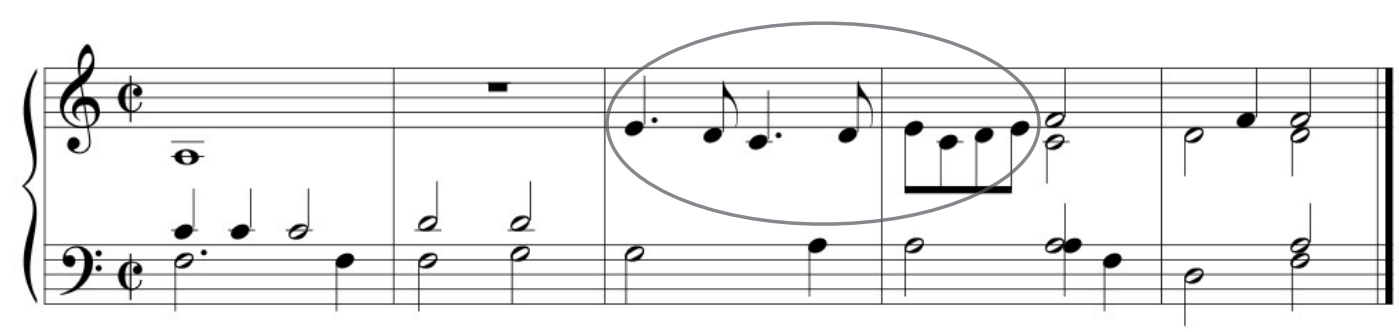

Fig. 2.23. - Exemplo de ornamentação que liga uma voz à outra transcrição da entabulação ornamentada (MINAMINO, 1988, p. 356).

Galilei defende que ao realizar uma entabulação não se deve ornamentar em excesso, pois a compreensão do contraponto não deve ser prejudicada. Canguilhem afirma que esse posicionamento de Galilei impede o uso de diagonais ${ }^{24}$, técnica muito utilizada por alaudistas da época, uma vez que essas dificultam a compreensão de cada voz separadamente. Ele afirma ainda que, nas diminuições, o respeito ao contraponto original inclui o respeito às regras de contraponto (CANGUILHEM, 2001, p. 68-69).

Canguilhem ainda ressalta que a crítica feita por Galilei, aos alaudistas que não respeitam essas regras ao realizar as diminuições, pode se estender a muitos alaudistas italianos que o precederam, se concordarmos com Howard Mayer Brown, que concluiu em um estudo acerca do repertório alaudístico do período que as diminuições e imitações que boa parte dos alaudistas realizava contribuíam para obscurecer a estrutura original da peça (BROWN apud CANGUILHEM, 2001, p. 70).

Canguilhem conclui que, para Galilei, as diminuições são possíveis e até necessárias nas entabulações (cadências finais) e podem ajudar a tornar o contraponto mais claro, mas não devem nunca fazer o oposto, dificultar a compreensão do contraponto original e sobretudo não devem

\footnotetext{
${ }^{24} \mathrm{O}$ termo diagonais foi utilizado por Jean-Michel Vaccaro no livro, La musique de luth en france au XVI siècle. O autor considera que as diagonais são diminuições que ligam uma voz à outra (como no exemplo da fig. 2.22). Esse tipo de ornamentação considera toda a tessitura polifônica do trecho, transforma em continuidade a descontinuidade vertical do original vocal ao criar uma melodia diagonal (VACCARO, 1981, p. 198).
} 
infringir regras de contraponto (CANGUILHEM, 2001, p. 73). O musicólogo afirma ainda que a prudência de Galilei em relação às diminuições não se estendia aos outros entabuladores. Le Roy afirma que transcrever as notas para tablatura é apenas uma etapa intermediária do processo, que só está terminado com a transformação do modelo vocal por meio das diminuições, o que segundo Canguilhem era a prática usual da época. Para Le Roy, realizar as diminuições significava inclusive sacrificar algumas notas do original, para tornar a execução mais fácil. Canguilhem afirma que isso se dava porque diferentemente de Galilei, cujo princípio fundamental era o respeito ao contraponto original, Le Roy preocupava-se mais com a beleza da peça e com o resultado auditivo (CANGUILHEM, 2001, p. 74). 


\subsection{Significado da entabulação para Galilei}

A maioria dos alaudistas da época realizava entabulações com intuito de executá-las no alaúde, por isso apresentam de forma bem resumida as técnicas envolvidas no processo de entabulação. Galilei, por outro lado, dedica várias páginas do Fronimo ao que Canguilhem considera ser um tratado de contraponto. Canguilhem afirma que o tratado de Galilei, diferentemente dos demais tratados de entabulação, tem a função de ser objeto de estudo para que o instrumentista possa aperfeiçoar-se nas técnicas contrapontísticas e composicionais. Assim, as tablaturas seriam para ele um meio e não um fim.

Os diferentes objetivos ao entabular uma peça resultou em diferentes estilos de entabulações e em processos de entabulação distintos. Como foi visto acima, existiam duas concepções principais acerca de como deveriam soar as entabulações para alaúde. Ambas produzem peças instrumentais que não são um uma cópia exata do original vocal. A diferença entre as duas é na distância que cada uma está do original.

O modelo exemplificado por Albert de Rippe e Adrian Le Roy resulta em peças bastante ornamentadas que em alguns casos pouco lembram o original. O processo de entabulação deles parece ser de criar uma tablatura que contenha todas as vozes entabuladas quase que literalmente $\mathrm{e}$ que serve como base para a criação da versão final ornamentada. Pode-se considerar que a ornamentação foi criada já em um estilo instrumental, ou seja, a partir da tablatura literal criada. O modelo defendido por Galilei previa a criação de uma grade em notação mensural antes da criação da versão final em tablatura. Nesse modelo, não havia muitas ornamentações e ambicionava-se preservar ao máximo a estrutura do contraponto original.

Segundo Galilei, o símbolo de tenuto somado ao conhecimento da teoria do contraponto permite ao leitor de tablaturas transcrever a tablatura de volta para a partitura (CANGUILHEM, 2001, p. 88). O alaudista considerava equivalentes a partitura e a tablatura, ou seja, não uma notação prescritiva apenas. A forma como Galilei criava suas entabulações permitia dois usos além da execução instrumental: o estudo de teoria musical e para colecionar peças vocais. Existem evidências que outros compositores do período também faziam uso da tablatura para estudar contraponto e técnicas de composição como é o caso de Palestrina (OWENS, 1998, p. 42-48). Essa visão das entabulações também é compartilhada por Minamino. Ele considera ainda que as tablaturas criadas como preparação para a versão final também poderiam ter outras funções, como estudo de contraponto ou técnicas composicionais. (MINAMINO, 1988, p. 50). 


\section{CAPÍTULO 3 - TEORIA COMPOSICIONAL}

\subsection{Concepção simultânea}

Bonnie J. Blackburn (1987) em seu artigo, On compositional process in the fifteenth century, descreve o trabalho realizado por Edward Lowinsky acerca do surgimento da concepção polifônica da música. Segundo Lowinsky25, uma mudança no estilo de escrita musical foi acompanhada pelo abandono do estilo de composição sucessivo em favor do simultâneo. Nesse mesmo artigo, Lowinsky definiu três formas de composição simultânea: o estilo imitativo, o estilo homofônico, e uma forma mista. Mais tarde ele adiciona a essas três o estilo de composição canônica.

Blackburn pretende confirmar que a concepção simultânea foi um fenômeno que surgiu no início do século XV e que ele coexistiu com composições sucessivas durante o século XV e XVI, tanto no estilo imitativo quanto no homofônico. Ela afirma que até a data da publicação do artigo essa questão ainda não havia sido reconhecida devido a uma compreensão errada do termo res facta ${ }^{26}$, da forma como havia sido utilizado por Tinctoris, e a utilização indiscriminada dos termos concepção simultânea e composição sucessiva para designar o mesmo fenômeno.

Blackburn (1987, p. 219-224) tenta definir o conceito de concepção simultânea baseada nas obras de Pietro Aaron (1489 - 1545), Institutione harmonica e Il Toscanello. Ela afirma que a ideia de concepção simultânea das vozes está clara nesses tratados. Ele ressalta que para que a composição seja simultânea é necessário que o compositor tenha em mente o lugar de cada voz durante todo o processo de criação. Apenas em alguns exemplos presentes no Institutione harmonica aparecem exemplos de composições simultâneas, tanto homofônicas como imitativas (BLACKBURN, 1987, p. 217). Blackburn ressalta, no entanto, que, embora haja evidências de que as composições baseadas em acordes existissem, elas não necessariamente significavam que eles tivessem o entendimento funcional que surgiria no século XVII.

Ainda nesse artigo ela trata da relação entre os processos de composição contrapontísticos horizontais e verticais (BLACKBURN, 1987, p. 224-233). Blackburn afirma que, em Johannes Tinctoris (1435 - 1511), já está presente a nova forma de compor citada por Aaron. Uma das evidências apresentadas é uma carta de Giovanni Spataro que fala da perda de interesse na

\footnotetext{
${ }^{25}$ Edward Lowinsky (1948).

${ }^{26} \mathrm{O}$ conceito será discutido no capítulo 3.1.1.
} 
utilização das técnicas de contraponto que podia ser percebida já na primeira metade do século XVI (BLACKBURN, 1987, p. 220). Ela contraria o argumento de Richard Crocker e Leeman Perkins ${ }^{27}$ que afirmavam que a preocupação dos compositores do século XVI era melódica, o que explicava o fato de eles terem se voltado para o desenvolvimento do sistema modal. Blackburn os acusa de ignorar a distinção feita por Aaron entre o estilo antigo e o novo, que segundo a autora diferenciavam-se na forma de concepção. No estilo novo, as composições não seriam mais baseada apenas no desenvolvimento melódico das duas vozes principais.

Em The dispute about harmony c. 1500, Blackburn traz novos indícios acerca da concepção de acordes no século XVI. Ela demonstra que autores como Giovanni Spataro usavam o termo harmonia como sinônimo de composições com mais de três vozes (BLACKBURN, 2001, p. 9). Mais além, ela considera que o conceito de acorde está presente nos textos de Spataro e Aaron, mas ambos se referiam a eles como intervalos mediados, por exemplo, Octava harmonice mediata referia-se ao que se considera no presente um acorde de quinta e oitava (BLACKBURN, 2001, p. 12). Dessa forma, a autora quer demonstrar sua teoria de que já na primeira metade do século XVI os compositores não estavam baseadas apenas na estrutura de duas vozes do século XIV e XV.

Margaret Bent (1998) discorda dessa classificação de Blackburn. Segundo Bent, o termo diádica representa melhor o processo composicional dos séculos XIV, XV e XVI, o que segundo a autora é mais relevante do que compreender se a composição das vozes se deu simultânea ou sucessivamente. Isso porque as obras eram compostas levando em consideração a relação do tenor com o cantus, a forma de interação se dava principalmente a duas vozes. Ela diz que o fato dos tratados de contraponto da época descreverem principalmente o contraponto a duas vozes é evidência dessa técnica de composição.

A teoria de Bent coloca que as demais vozes presentes na polifonia seriam adições à estrutura da composição, a relação contrapontística entre cantus e tenor. Por isso, a relevância de se saber se o compositor teria ou não pensado todas as vozes simultaneamente no processo de composição pode ser relativizada. Essa maneira de compreender as polifonias vocais do século XV e XVI é corroborada pela análise das características formais dessas peças. Nos capítulos que seguem, poderá ser visto como as cadências e a teoria modal parecem reforçar essa maneira de compreender a estrutura polifônica.

\footnotetext{
${ }^{27}$ Crocker (1962), Perkins (1973).
} 


\subsubsection{Contraponto $x$ composição}

Segundo Blackburn (1987, p. 276), podemos inferir a partir dos textos teóricos da época que havia, no século XV, uma diferenciação entre o estudo de contraponto e as técnicas composicionais. Para explicar essa diferença, é necessário compreender a distinção entre o conceito de res facta e de contrapunctus. Ela discute os trabalhos de Ernest T. Ferand e Margaret Bent ${ }^{28}$ acerca do tema e propõe uma outra perspectiva sobre o assunto.

A definição de Ferand para res facta era de um contraponto florido escrito, ou seja, nãoimprovisado, essa seria a característica que o diferenciaria do cantare super librum, esse improvisado, na visão do musicólogo (BLACKBURN, 1987, p. 248). Bent critica essa posição por considerar que ela não leva em consideração o contexto em que Tinctoris as utilizava em seus trabalhos. Ela considera que houve uma confusão na compreensão do termo cantare super librum ${ }^{29}$, o qual Ferand interpreta como improvisação. Bent, por outro lado, considera que cantare super librum pode ser uma referência, também ao processo de pensar a composição antes de escrevê-la. Bent chega então a seguinte definição: res facta é uma composição — usualmente, mas nem sempre, escrita - uma peça completa resultante da aplicação das regras de contraponto entre as partes e da obediência as regras de resolução de dissonâncias (BLACKBURN, 1987, p. 250). Cantare super librum, para essa autora significava cantar contraponto de acordo com as regras de combinação de vozes, mas não necessariamente de maneira improvisada.

Blackburn traz então sua própria compreensão sobre o tema. Segundo a autora, Tinctoris considerava que contrapunctus era uma forma de composição sucessiva, na qual uma voz é adicionada a outra já composta, ele pode ser simples ou diminuído. Res facta consiste em uma peça de três ou mais vozes, uma subordinada a outra, respeitando as regras de consonâncias. A principal diferença, segundo Blackburn, portanto é que no contrapunctus cada voz deve ser consonante com o tenor e na res facta elas devem ser consoantes entre si (BLACKBURN, 1987, p. 252). O primeiro tipo representa um exemplo de composição sucessiva e o último pode ser tanto sucessiva quanto simultânea.

\footnotetext{
${ }^{28}$ Ernest T. Ferand, What is "Res Facta"? JAMS, 1957 e Margaret Bent, Res Facta and Cantare super librum JAMS, 1983.

${ }^{29}$ Técnica de contraponto, em que os cantores improvisavam polifonia sobre um tenor escrito.
} 


\subsubsection{Relação com a entabulação}

Blackburn introduz um outro conceito para explicar o processo composicional desse período: composição harmônica, por ele trazer a ideia da concepção vertical das peças e por ele se adequar ao conceito de harmonia da época: resolver dissonâncias em consonâncias (BLACKBURN, 1987, p. 266). Esse conceito é importante para a compreensão dos processos de entabulação. Como foi visto no capítulo anterior, Galilei demanda do entabulador a correção do contraponto realizado pelo compositor e que as alterações que forem essenciais para a entabulação sejam feitas de acordo com as regras de contraponto. Essa forma de entabular corrobora o estilo de composição descrito por Blackburn, uma vez que dificilmente se poderia realizar as tarefas propostas por Galilei sem uma concepção simultânea das vozes.

Blackburn afirma que podemos descobrir se o compositor utilizou o processo simultâneo (composição harmônica) pela análise do uso das dissonâncias. As principais características a serem observadas são erros de contraponto entre as partes, como por exemplo, se há quartas entre o tenor e as vozes superiores, embora, no final do século XVI alguns teóricos considerassem a quarta como uma consonância. O processo, no entanto, pode começar simultâneo, seguir sucessivo e ser refinado harmonicamente. Esse refinamento harmônico deve ter sido muito importante para composições imitativas, que necessitam de adaptações nas vozes para possibilitar as imitações. Lowinsky afirma que foi esse o período em que começou a ser usadas grades para a composição (BLACKBURN, 1987, p. 268). A forma como eram utilizadas as grades também se mostraram relevantes para a compreensão das entabulações, pode-se perceber que o estilo de entabulação de Rippe e Le Roy não necessitava de grades, enquanto que as entabulações no formato defendido por Milano e Galilei as necessitavam.

Essa concepção de que as vozes eram compostas simultaneamente, e principalmente compostas imitativamente mostra que nessas peças todas as vozes são estruturais e essenciais. No entanto, devemos investigar como esse conceito era recebido pelos entabuladores, uma vez que sempre eram necessárias adaptações para a execução solo no alaúde, principalmente para peças a quatro vozes ou mais. Como vimos no capítulo anterior, Galilei hierarquiza as vozes, sendo para ele mais importantes as vozes externas, uma vez que ele recomenda que não se retire nenhuma nota dessas vozes. 


\subsection{Uso de dissonâncias}

No século XVI, a primeira teoria harmônica criada por Zarlino, no livro dois da Institutione Harmoniche, traz, além do conceito de harmonia presente nos textos clássicos, as ideias de teóricos do século XV. Ele qualifica a harmonia em perfeita ou imperfeita e própria ou imprópria. A harmonia própria seria a mistura de sons graves e agudos, mediados ou não, em que consonâncias e dissonâncias se alternam em direção ao final. Se existem três ou mais partes, a harmonia é perfeita. Com duas partes ainda há harmonia, mas ela é imperfeita. Harmonia imprópria seria aquela em que só há consonâncias, ou seja, não há movimento (BLACKBURN, 1987, p. 230). Bonnie Blackburn afirma, no entanto, que Zarlino não chega a dizer que as dissonâncias tem um papel fundamental no movimento de tensão e resolução dentro das peças, mas o fato de ele distinguir entre os conceitos de harmonia e consonância ao afirmar que o primeiro possui movimento, indica que ele conhecia a função das dissonâncias (BLACKBURN, 1987, p. 232).

Blackburn (1987, p. 233-246) traz o estudo sobre como as dissonâncias eram percebidas até o século XVI. Muito poucos tratados de contraponto traziam uma definição de dissonância, porque eles trabalhavam com contraponto nota contra nota a duas vozes, nos quais as dissonâncias praticamente não aparecem. As primeiras menções ao uso de dissonâncias são feitas no fim do século XIV e estão ligadas ao contraponto diminuído, em que o cantus canta várias notas sobre uma nota lenta do tenor. Nas figuras 3.1 e 3.2, pode-se ver um exemplo de como essa espécie de contraponto existia na música para alaúde, nesse dueto de alaúdes um dos instrumentistas toca uma entabulação das vozes da peça vocal, enquanto o outro executa o contraponto diminuído. O tratado de Guilielmus Monachus do fim do século XV é o primeiro em que as dissonâncias são tratadas de maneira funcional, isto é, enriquecendo a consonância que a segue. Um tratado anônimo do final do mesmo século já traz a ideia de que um contraponto sem dissonâncias não gera harmonia. Como já foi visto essa ideia seria retomada por Zarlino.

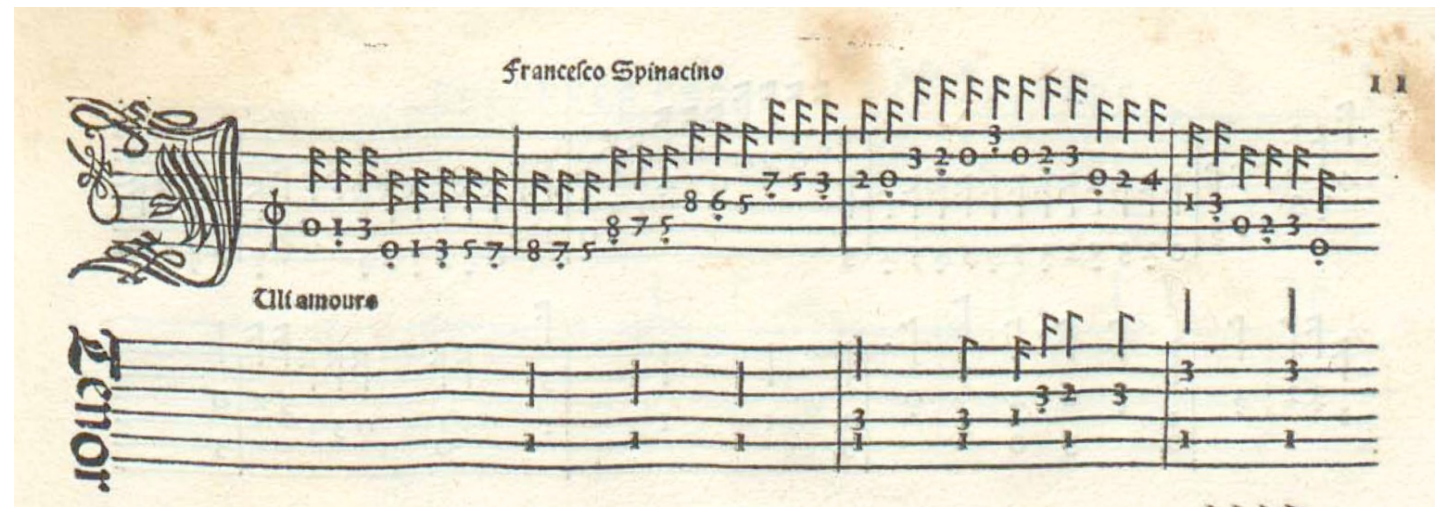

Figura 3.1 - Exemplo de contraponto diminuído em tablatura (SPINACINO, 1507, fol. 11). 

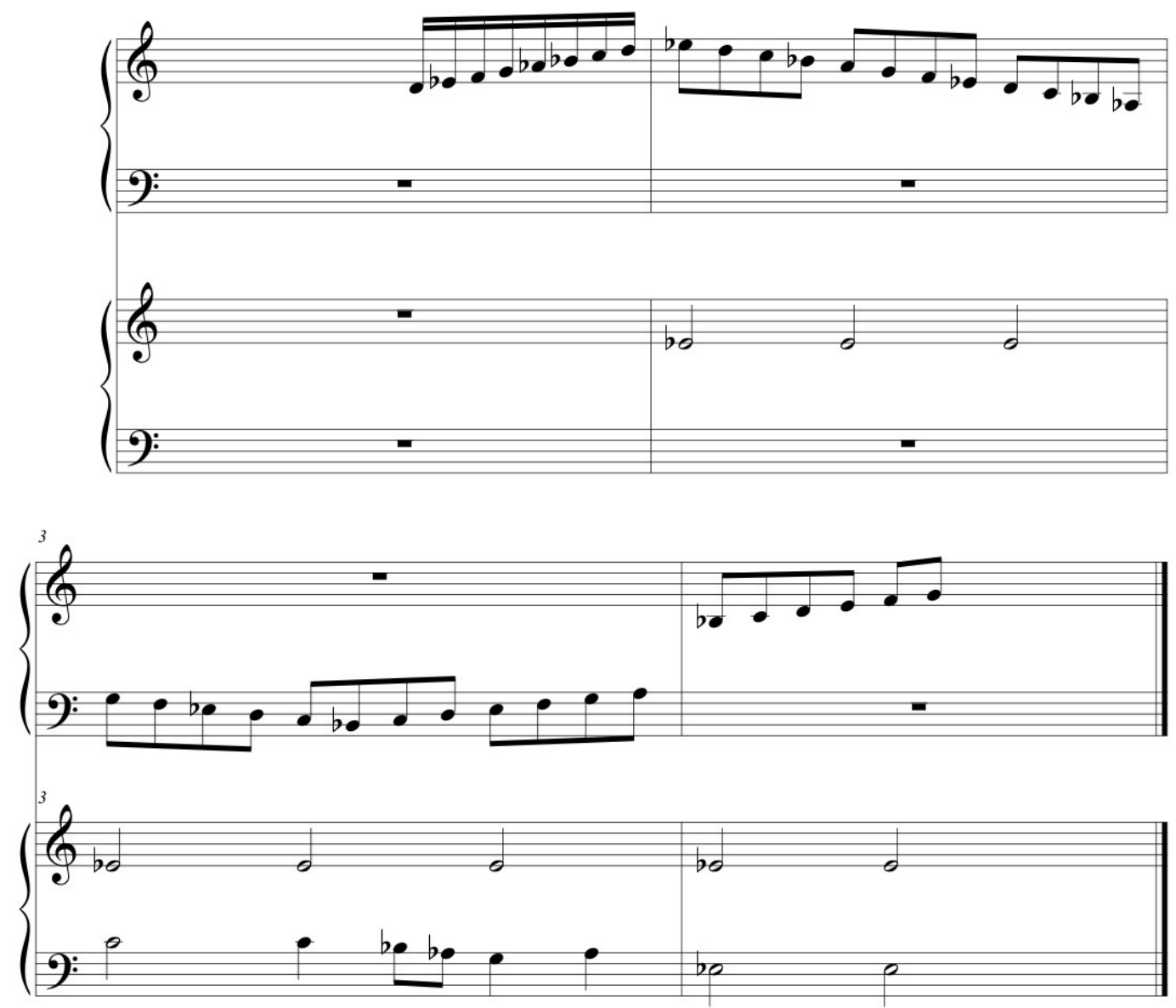

Figura 3.2 - transcrição do exemplo de contraponto diminuído em tablatura (SPINACINO, 1507, fol. 11).

$\mathrm{Na}$ análise da teoria de Tinctoris acerca do uso de dissonâncias e como isso influencia a perspectiva de uma teoria da harmonia, Blackburn afirma que a inovação de Tinctoris é o fato de ele ter dedicado uma parte significativa de seu tratado ao estudo das dissonâncias e que isso possibilita a compreensão do processo composicional do período. De acordo com a autora, essa teoria acerca do uso das dissonâncias se adequaria ao que Spataro afirmava ser uma teoria da harmonia (BLACKBURN, 1987, p. 244). Diferentemente de Spataro, no entanto, Tinctoris nos dá a forma como essas dissonâncias eram utilizadas, por exemplo, as mais fortes eram utilizadas nas cadências.

A análise das dissonâncias pode demonstrar ser de grande interesse para a compreensão da estrutura das cadências, principalmente para definir quais cadências são mais importantes e, dentro das cadências quais vozes são imprescindíveis. Blackburn, no entanto, afirma que todas as vozes são consideradas estruturais, pois as vozes se comportam diferentemente em passagens cadenciais ou não-cadenciais (BLACKBURN, 1987, p. 244). Essa afirmação tem uma relação importante com o processo de entabulação, uma vez que durante o processo algumas vozes podem perder algumas notas. Como foi exposto no capítulo anterior, Galilei nos dá algumas indicações de como escolher 
as notas que podem ser omitidas da entabulação. Parece interessante ressaltar que ele não recomenda a retirada de nenhuma dissonância.

Uma das inovações teóricas que Galilei trouxe para o contraponto do século XVI foi o seu tratamento das dissonâncias. Segundo Claude Palisca (1956, p. 87), Galilei considerava as dissonâncias a parte mais importante do contraponto. Galilei acreditava que o uso das dissonâncias devia ser mais livre, para que a música pudesse mover as paixões da alma.

“... três intervalos para as [consonâncias] perfeitas, dois para as consonâncias imperfeitas e quatro para as dissonâncias. E esses julgo suficientes para poderem os músicos, com a diversidades dos movimentos posteriores e velozes, e com a variedade de notas graves e agudas, exprimir todos os afetos e paixões da alma,..." ${ }^{30}$ (GALILEI apud REMPP, 1980, p. 82)

Klaus-Jürgen Sachs (2007, p. 12), lista as principais inovações de Galilei com relação ao tratamento de dissonâncias:

1. Em uma sequência de quatro semínimas, duas podem ser dissonantes em qualquer posição, e ocasionalmente três podem ser dissonantes consecutivamente.

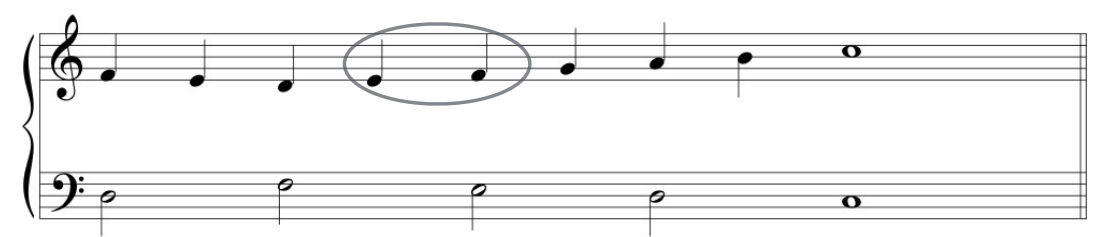

Figura 3.3 - Inovações no tratamento das dissonâncias de Vincenzo Galilei (SACHS, 2007, p. 13).Exemplo 1.a.

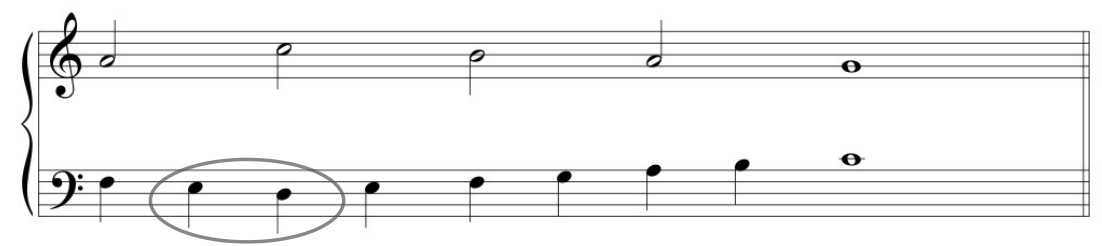

Figura 3.4 - Inovações no tratamento das dissonâncias de Vincenzo Galilei (SACHS, 2007, p. 13).Exemplo 1.b.

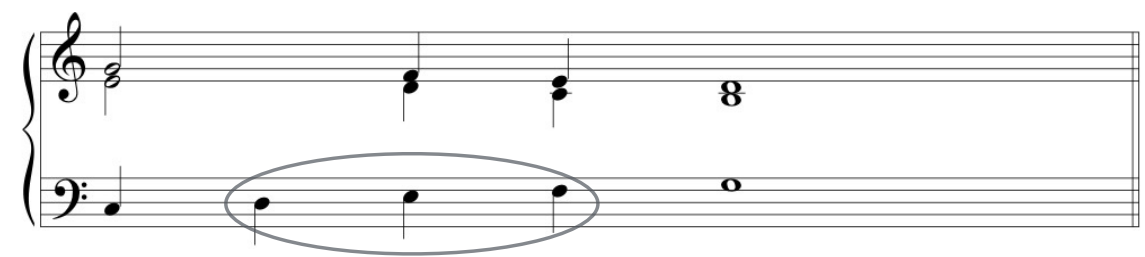

Figura 3.5 - Inovações no tratamento das dissonâncias de Vincenzo Galilei (SACHS, 2007, p. 13).Exemplo 1.c.

30 “... tre intervalli per la perfettione, due per l'imperfettione delle Consonanze; et quattro per le Dissonanze. et questi giudico suffizienti di potere con essi i Musici, insiemi con la diversità de moti tardi, et veloci; et con la varietá delle corde gravi et dell'acute, esprimire tutti gl'affetti et passioni dell'animo,..." (GALILEI apud REMPP, 1980, p. 82). 
2. Suspensões podem ser resolvidas por salto para uma consonância;

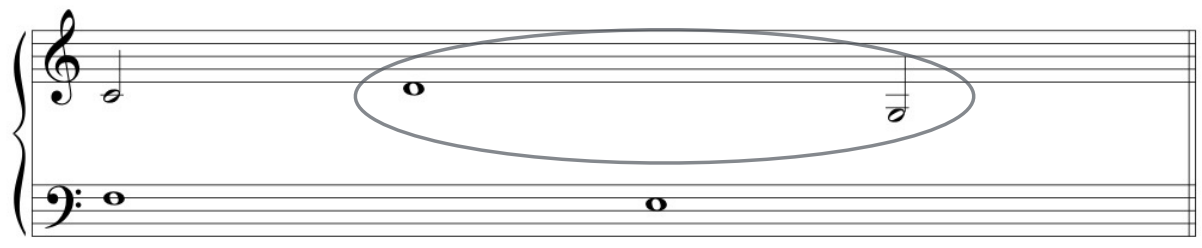

Figura 3.6 - Inovações no tratamento das dissonâncias de Vincenzo Galilei (SACHS, 2007, p. 13).Exemplo 2.

3. Por progressão para uma nova dissonância;

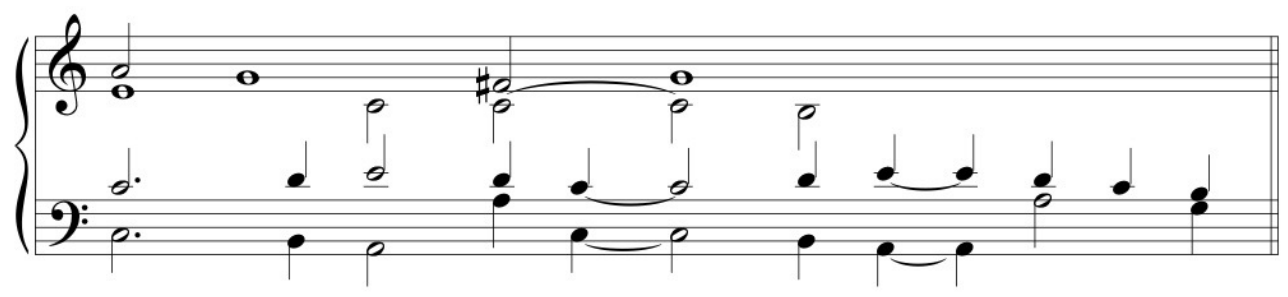

Figura 3.7 - Inovações no tratamento das dissonâncias de Vincenzo Galilei (SACHS, 2007, p. 13). Exemplo 3.

4. De forma ascendente para uma consonância;

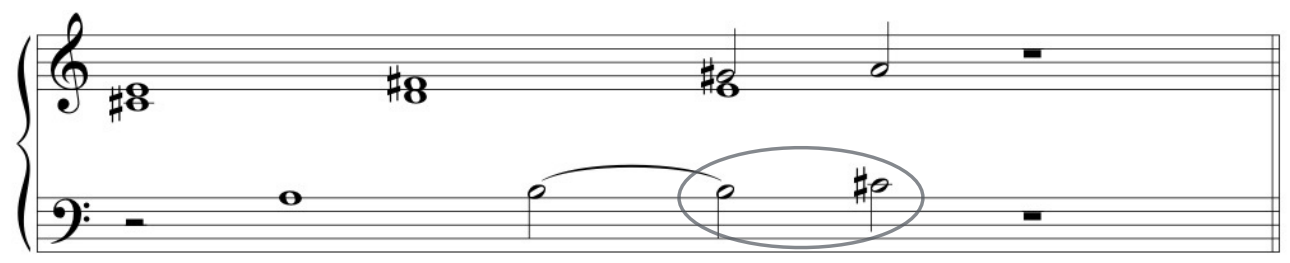

Figura 3.8 - Inovações no tratamento das dissonâncias de Vincenzo Galilei (SACHS, 2007, p. 13).Exemplo 4.

5. Simultaneamente com uma parte em progressão cromática;

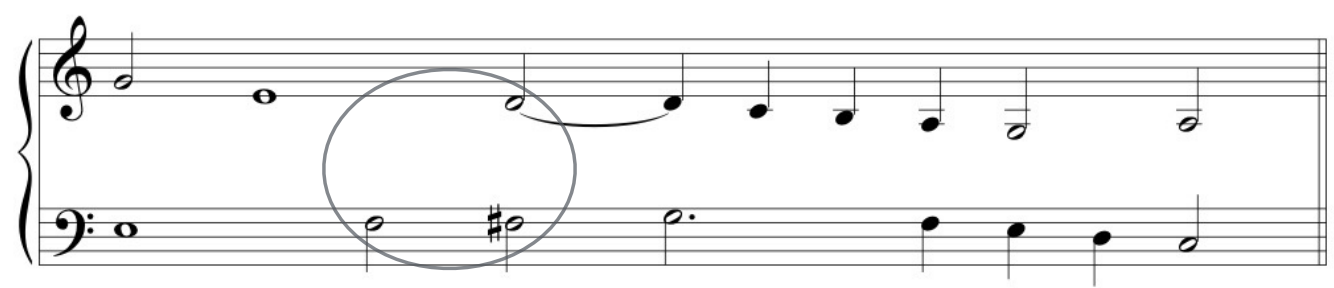

Figura 3.9 - Inovações no tratamento das dissonâncias de Vincenzo Galilei (SACHS, 2007, p. 13).Exemplo 5.

6. Podem ocorrer várias de uma vez.

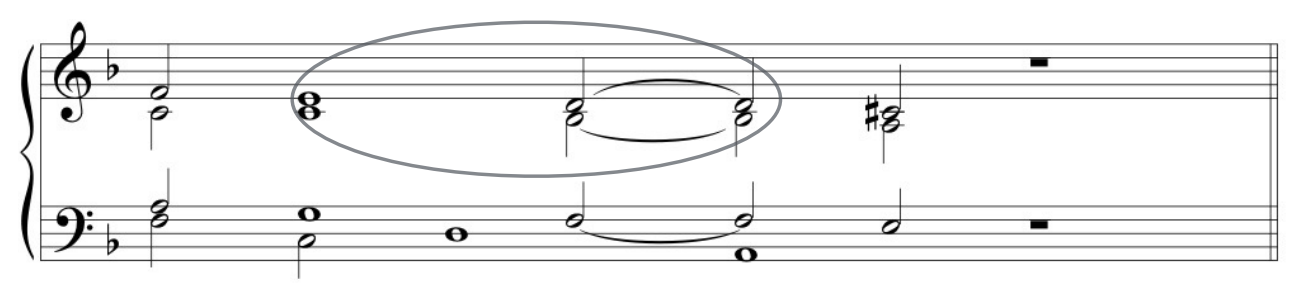

Figura 3.10 - Inovações no tratamento das dissonâncias de Vincenzo Galilei (SACHS, 2007, p. 13).Exemplo 6. 
7. Dissonâncias podem ocorrer na parte forte do tempo, sem preparação sincopada, se seguida por uma resolução regular.

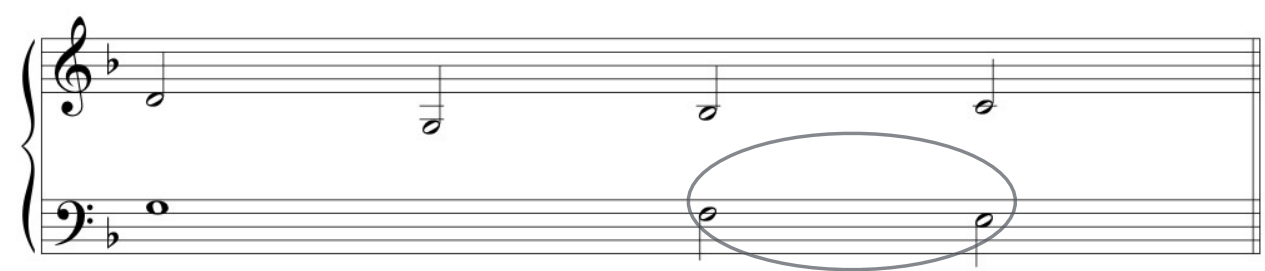

Figura 3.11 - Inovações no tratamento das dissonâncias de Vincenzo Galilei (SACHS, 2007, p. 13).Exemplo 7.a.

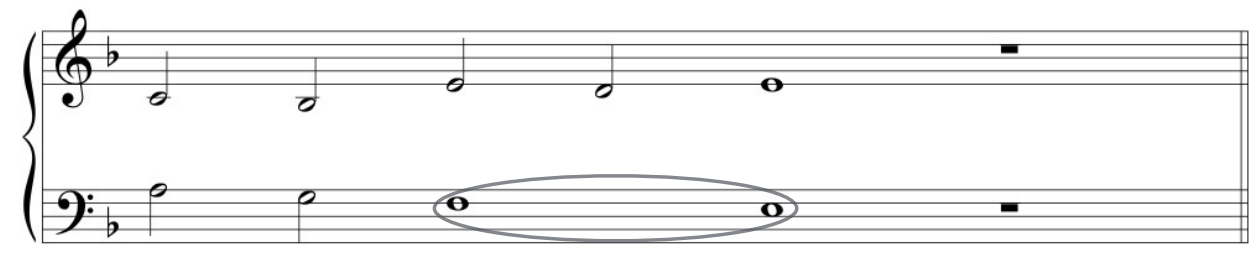

Figura 3.12 - Inovações no tratamento das dissonâncias de Vincenzo Galilei (SACHS, 2007, p. 13).Exemplo 7.b.

A análise do uso das dissonâncias é essencial para compreender como está estruturado o contraponto. A interpretação das cadências também depende da capacidade de diferenciar as espécies de dissonâncias. Galilei relaciona o uso das dissonâncias a expressão do texto nas peças vocais $^{31}$, portanto conhecer a forma como as dissonâncias são usadas pelos compositores da época pode ser uma indicação do caráter da peça, o que como veremos mais adiante também ajuda a definir o modo da peça.

${ }^{31} \mathrm{O}$ principal trabalho de Galilei acerca do uso de dissonâncias está no manuscrito de seu tratado de contraponto escrito em 1591. Uma edição moderna desse tratado foi publicada por Frider Rempp em 1980. 


\subsection{Cadências}

Segundo Anne Smith (2011, p. 72), John Hothby, compositor e teórico do século XV, comparava as cadências à pontuação textual. Esse tipo de comparação é uma evidência da importância que as cadências tinham para a compreensão retórica da polifonia seiscentista. A principal função das cadências era evidenciar para músicos e ouvintes a estrutura musical e sua relação com o texto.

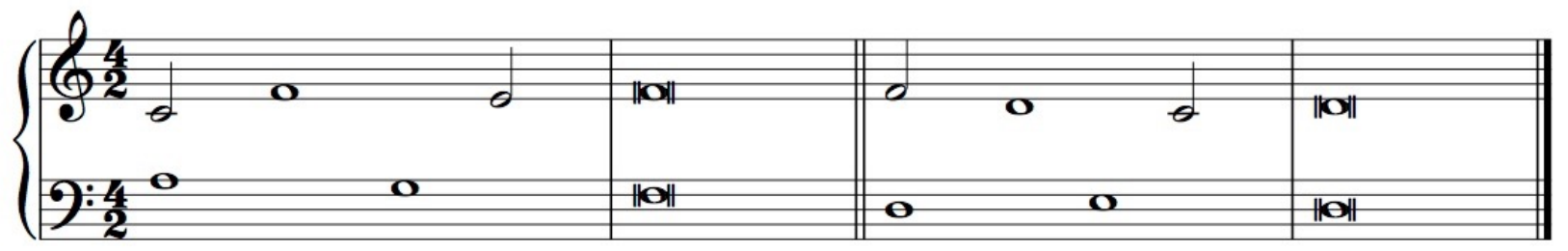

Figura 3.13 - Cadências perfeitas.

Com efeito, a prescrição dos teóricos do século XVI em relação às cadências em peças vocais era que ela estivesse de acordo com a pontuação do texto. Segundo Zarlino, "É bom termos essas cadências evitadas. Elas são úteis quando um compositor no meio de uma bonita passagem tem necessidade de uma cadência, mas não pode escrever uma, porque o ponto no texto não coincide, e não seria honesto inserir um" (ZARLINO, 1558, p. 225).

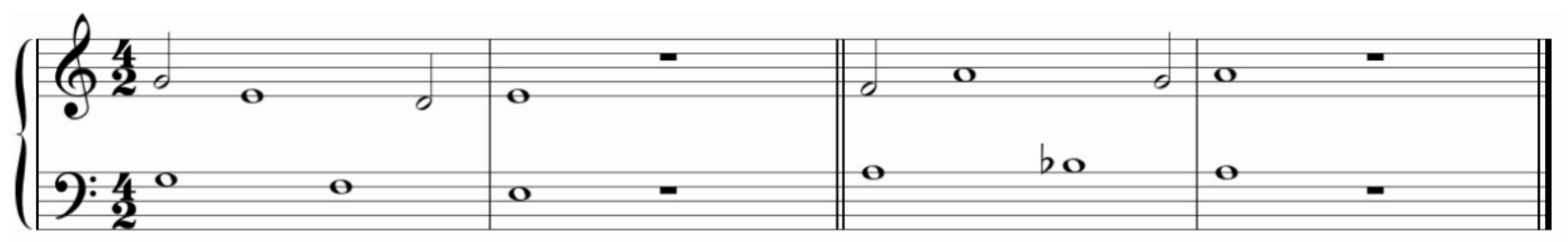

Figura 3.14 - Cadências frígias.

Smith afirma que as cadências eram definidas por estruturas de duas vozes. As duas principais eram a clausula cantisans e a clausula tenorisans. Na primeira, a voz desce uma segunda e volta. Na segunda, existem duas possibilidades: a voz sobe uma segunda e volta, ou a voz desce três notas em graus conjunto (SMITH, 2011, p. 75). O resultado é uma cadência perfeita, uma sétima atingida por síncope seguida por uma sexta maior que resolve em uma oitava (fig. 3.13). A autora coloca que as outras vozes foram criadas partindo dessa relação entre tenor e soprano. Ela cita como exemplo a fórmula da quinta descendente no baixo. Ainda acerca das cadências finais, 
existe a cadência frígia (fig. 3.14). Nessa, existe o intervalo de semitom acontece na clausula tenorisans (SMITH, 2011, p. 76).

Além das cadências finais, existem as evitadas, como evidenciado acima por Zarlino. Smith traz uma lista que exemplifica as diferenças formas que essas cadências podem assumir ${ }^{32}$ :

1. Na clausula cantisans, a voz desce uma segunda, em vez de retornar para a nota de origem.

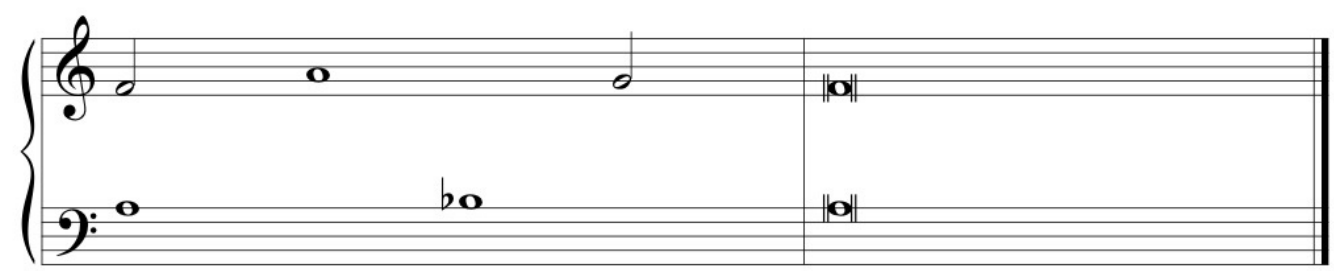

Fig. 3.15 - Exemplo de cadência evitada $n^{\circ} 1$.

2. Uma das vozes dá um salto (ainda que preenchido melodicamente) para outra consonância, que não a oitava.

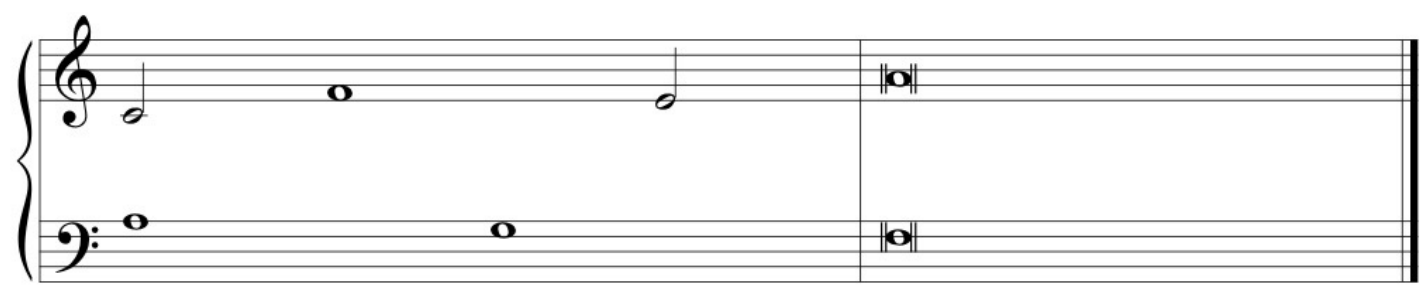

Fig. 3.16 - Exemplo de cadência evitada nº2.

3. O baixo, em vez da fórmula da quinta descendente, sobe ou desce uma terça.

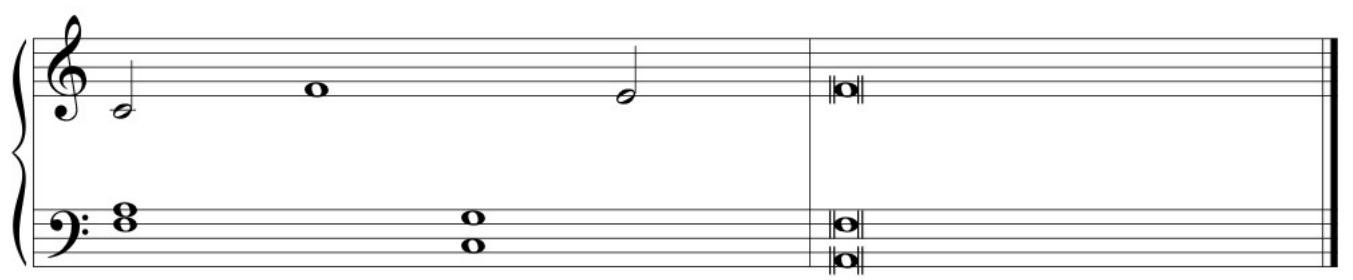

Fig. 3.17 - Exemplo de cadência evitada nº3. 
4. Em vez de mover-se da terça maior (com fórmula da quinta descendente no baixo) em direção à oitava, a voz superior faz um salto de terça, enquanto o baixo sustenta sua nota.

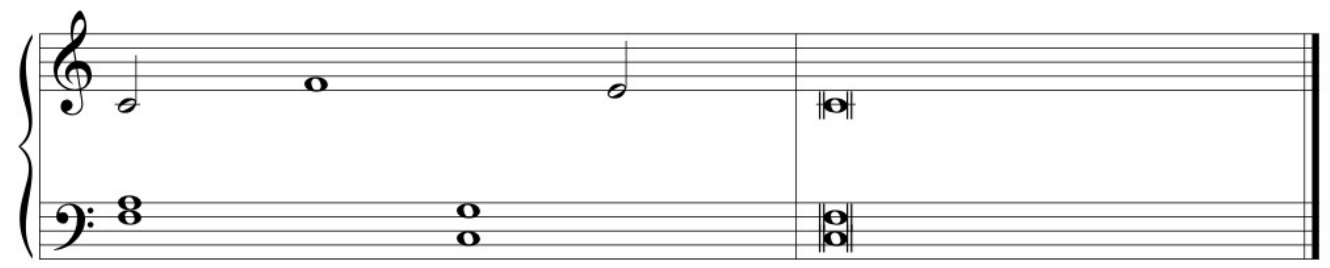

Fig. 3.18 - Exemplo de cadência evitada $\mathrm{n}^{\circ} 4$.

5. Quando a dissonância é iniciada por uma síncope, de forma a criar a expectativa da cadência, as vozes "resolvem" cedo, ou seja, se movem pra uma consonância diferente na parte fraca do pulso, evitando o movimento cadencial.

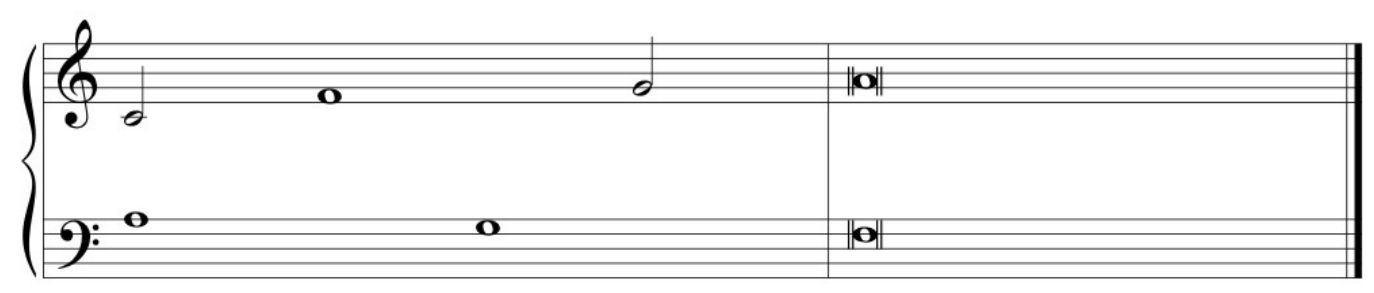

Fig. 3.19 - Exemplo de cadência evitada nº5.

6. O baixo, em vez de descer uma quinta, sobe uma segunda, para formar uma sexta com a voz superior ${ }^{33}$.

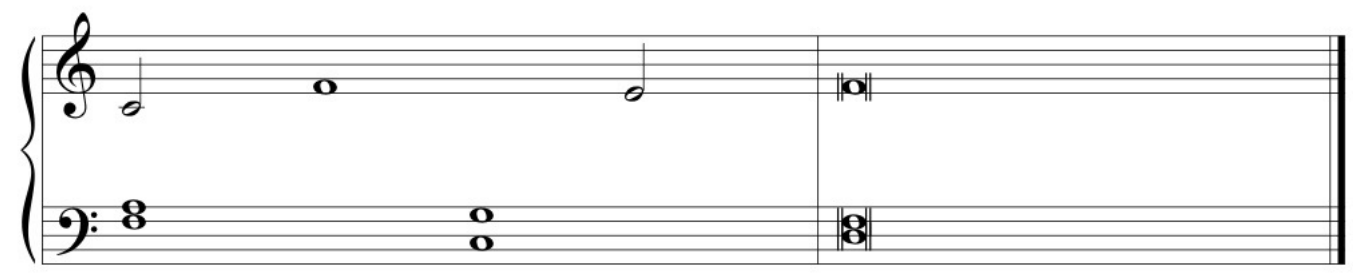

Fig. 3.20 - Exemplo de cadência evitada nº6.

7. A voz do baixo desce uma segunda junto com a voz superior, em vez da quinta esperada.

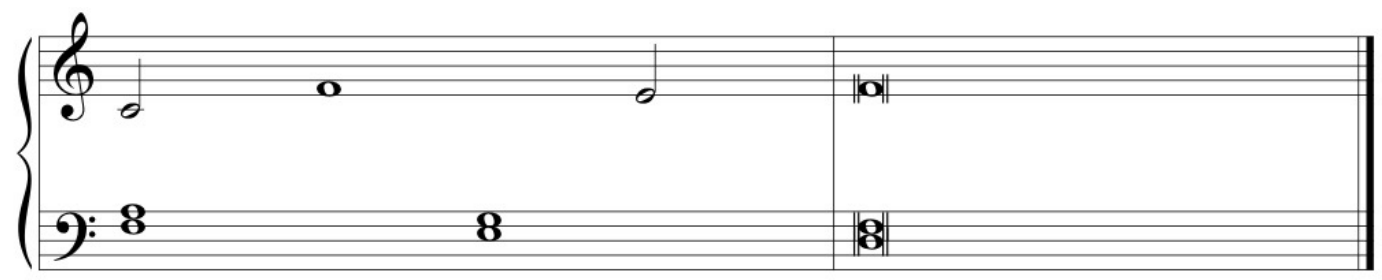

Fig. 3.21 - Exemplo de cadência evitada $\mathrm{n}^{0} 7$.

${ }^{33}$ Smith lembra que essa parece com o que conhecemos como cadência de engano, mas no século XVI essa era apenas uma das maneiras possíveis de se evitar uma cadência. 
8. Uma das duas vozes principais fica subitamente em pausa, no momento em que deveria soar a nota cadencial.

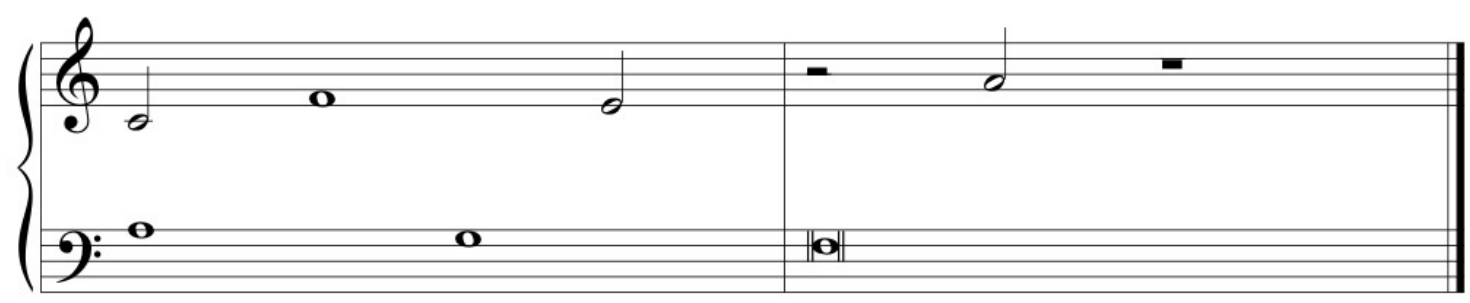

Fig. 3.22 - Exemplo de cadência evitada nº.

Smith alerta que, ao evitar uma cadência, deve-se ter cuidado para que, ao executar a musica ficta, não se incorra em erros de contraponto. Em alguns casos, a execução da ficta não será possível. No entanto, em outros, como nas cadências com saltos, poderá existir mais de uma possibilidade. Smith (2011, p. 81) traz exemplos retirados do tratado de Nicola Vicentino, L'antica musica ridotta alla moderna prattica, que mostram diferentes possibilidades de resolução para um cantor habilidoso. Ela demonstra ainda baseada em peças instrumentais de Antonio Cabezon e Albert de Rippe que o uso de ficta era bastante ousado, utilizando até mesmo intervalos proibidos, como o de quarta aumentada (SMITH, 2011, p. 83).

Judd afirma que a estrutura das cadências pode gerar uma hierarquia entre as mesmas e, ainda, que o movimento cadencial das vozes define as duas vozes estruturais de uma cadência (JUDD, 1985, p. 214). Segundo a autora, as principais cadências teriam as clausulas cantizans, tenorizans e bassizans ocorrendo em suas respectivas vozes, as duas vozes principais seriam a do cantus e do tenor (JUDD, 1985, p. 214). A escolha da nota em que se realiza a cadência também contribui para hierarquizar as cadências, as mais importantes acontecem na finalis (JUDD, 1985, p. 215). Apesar de as vozes principais serem as do cantus e do tenor, pode-se perceber pela análise das possibilidades de cadências evitadas que a clausula bassizans já possui valor estrutural no século XVI. 


\subsection{Modo}

Podemos identificar ao menos quatro usos para a teoria modal: Salmodia, cantochão, composição e polifonia (WIERING, 2001, pos. 1591). As primeiras teorias acerca da utilização dos modos preocupavam-se principalmente com os dois primeiros usos, no século XVI, as duas últimas ganham mais importância.

\subsubsection{Sistema de oito modos}

O debate acerca da teoria modal já era polêmico no século XVI. Segundo Frans Wiering (2001, pos. 267), existiam duas teorias: a primeira conhecida como eclesiástica-ocidental e a segunda como pseudoclássica. Na teoria eclesiástica-ocidental, as principais características utilizadas para diferenciar os modos são finalis, ambitus e tenor. As finalis são definidas pelas quatro diferentes espécies de tetracorde (Ré - Mi - Fá - Sol; Mi - Fá - Sol - Lá; Fá - Sol - Lá - Si; Sol - Lá - Si Dó). O primeiro tetracorde era chamado de Protus, os demais eram chamados respectivamente de Deuterus, Tritus e Tetrardus. As quatro finalis que geram os diferentes modos no sistema de oito modos são as notas que iniciam cada um dos tetracordes (Ré, Mi, Fá e Sol).

Existiam dois modos para cada finalis, um utiliza o âmbito melódico acima da finalis, os modos autênticos, e os modos plagais, aqueles em que é utilizada aproximadamente uma quarta abaixo da finalis. Com isso, temos os oito modos: as quatro finalis (Ré, Mi, Fá e Sol) e dois ambitus para cada uma delas (autêntico e plagal). Wiering traz um quadro (Quadro 3.1) que explica a diferença entre os modos. Wiering chama os modos que possuem a mesma finalis de modos complementares. É importante ressaltar que a forma escalar não é a característica mais importante para a diferenciação dos modos, dentro do modelo eclesiástico. Um conceito importante para a definição do modo é o de repercussio, uma nota que aparece com frequência em uma melodia. Ela é a quinta acima da finalis nos modos autênticos e uma quarta nos modos plagais, ele também pode significar as notas contidas nesses intervalos (WIERING, 2001, pos. 245).

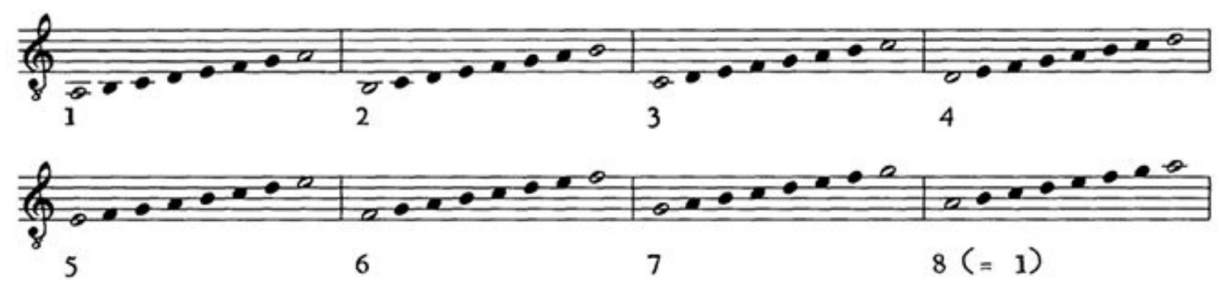

Figura 3.23 - Oito modos por espécies de oitavas. (WIERING, 2001, pos. 205). 


\begin{tabular}{|c|c|c|c|}
\hline Modo & Ambitus & Finalis & Tenor \\
\hline 1 & autêntico & Ré & Lá \\
\hline 2 & plagal & Ré & Fá \\
\hline 3 & autêntico & Mi & Dó \\
\hline 4 & plagal & Mi & Lá \\
\hline 5 & autêntico & Fá & Dó \\
\hline 6 & plagal & Fá & Lá \\
\hline 7 & autêntico & Sol & Ré \\
\hline 8 & plagal & Sol & Dó \\
\hline
\end{tabular}

Quadro 3.1 - Oito modos teoria eclesiástica-ocidental. (WIERING, 2001, pos. 210).

No modelo eclesiástico, a organização tonal entre psalm-tones e antífonas era considerada a principal função dos modos. Por isso o modelo classifica o modo de acordo com finalis, ambitus, e tenor (JUDD, 2002, pos. 10278). A maior preocupação era a classificação das antífonas e psalmtones, para que sua execução na igreja não fosse sem sentido. Havia pouca preocupação com as espécies de consonância presentes em cada modo.

Segundo Wiering, o modelo pseudoclássico origina-se de uma interpretação errada de Boécio. O filósofo chamava de modo as diferentes espécies de oitava, que eram sete, com a repetição da primeira para chegar aos oito modos. Wiering afirma que, na Idade Média, esse sistema teve seu auge com Marchetto da Padova. Esse teórico, no entanto, não classifica os modos segundo as espécies de oitava, mas segundo as espécies de quinta e quarta que somadas resultavam nas oitavas de cada modo (WIERING, 2001, pos. 286). Nos modos autênticos, sobrepunha-se uma das espécies de quarta a uma espécie de quinta, e, nos modos plagais, fazia-se o contrário. Dessa forma, ele contornava o problema de haverem apenas sete espécies de oitava para os oito modos. Os modos que teriam a mesma espécie de oitava $-1^{\circ}$ e $8^{\circ}$, ou dórico e hipomixolídio - ficavam diferenciados. O primeiro formado pela quinta Ré-Lá mais a quarta Lá-Ré; e o oitavo seria formado pela quarta Ré-Sol mais a quinta Sol-Ré.

O modelo pseudoclássico relacionava a teoria modal com as sílabas de solmização, ou seja, além do ambitus e da finalis, as espécies intervalares poderiam auxiliar a definição do modo. Essa característica é de grande relevância para a definição do modo de uma composição polifônica. Powers e Wiering (2007, p. 9) afirmam que a definição do modo se dá pela finalis e pelas espécies 
de quarta e quinta, sendo que as notas escolhidas para as cadências devem concordar com essas outras categorias.

\subsubsection{Sistema de doze modos}

Glareanus (1488 - 1563) tentou tentou demonstrar em seu tratado que os quatro modos que estavam sendo acrescidos originavam-se do mesmo processo de combinar cada espécie de quarta a cada uma das espécies de quinta, com isso ele queria demonstrar que esse sistema era uma alteração do sistema de oito modos, não uma criação nova (POWERS; WIERING, 2007, p. 13). Essa combinação resultou em 24 espécies de oitava diferentes. Após retirar as que não atendiam aos critérios de harmonia da época — semitons separados por mais de três tons ou por menos de dois -, ele obteve os doze modos consonantes e os dois modos dissonantes de seu famoso Dodecachordon.

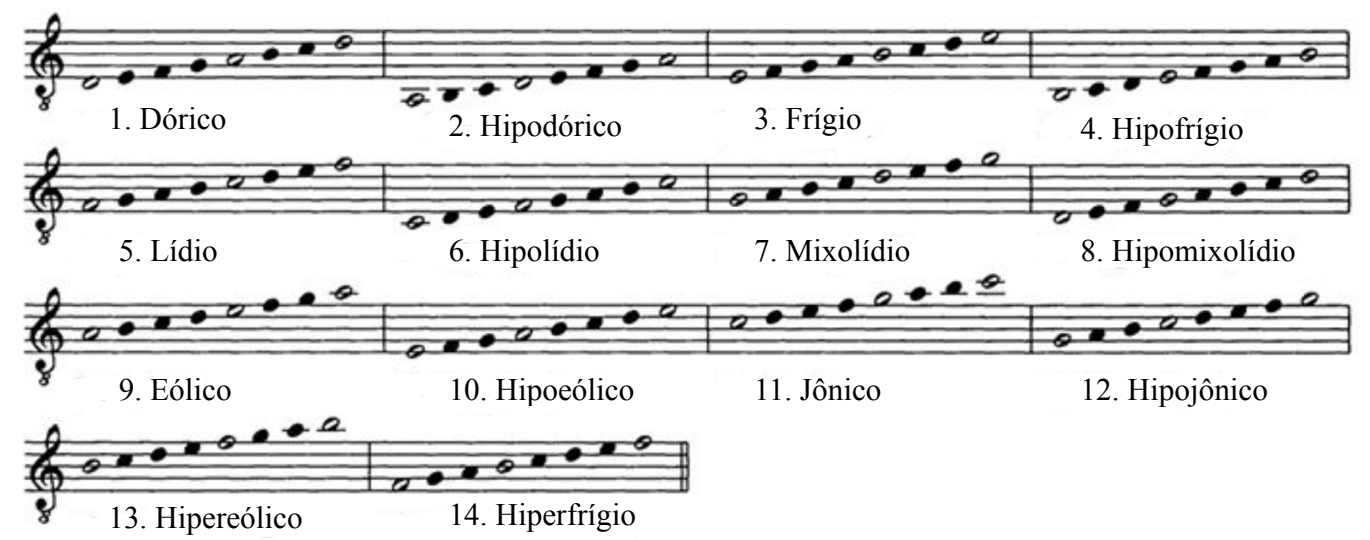

Figura 3.24. - Os 12 modos de Glareanus e os 2 modos dissonantes. (WIERING, 2001, pos. 292).

$\mathrm{Na}$ figura 3.24, pode-se perceber que os dois modos dissonantes são os que tem a finalis em $\mathrm{Si}$, o que resultava em um trítono tanto na espécie de quinta do modo hipereólico quanto na espécie de quarta do modo hiperfrígio. Os demais modos temos 5 pares que compartilham a mesma espécie de oitava: dórico e hipomixolídio; hipodórico e eólico; frígio e hipoeólico; hipolídio e jônico; e mixolídio e hipojônico. Os outros dois são as duas espécies de oitava que fariam par com os dois modos dissonantes, hipofrígio e lídio. Os autores afirmam ainda que por conta do foco na divisão da oitava Glareanus era forçado a concordar que a principal diferença entre os modos era a posição dos semitons (POWERS; WIERING, 2007 p. 12-14).

O fato de Glareanus considerar que a posição dos semitons dentro da coleção de notas diferencia um modo de outro significa que a presença de um bemol na armadura indica uma 
transposição. a mais frequente era a do modo 5, para evitar o trítono Fá-Si. A utilização costumeira do Si bemol agora indicaria que a peça estava escrita no modo 11 com a Finalis em Fá. Outro modo que frequentemente aparecia com um bemol era o modo 1 com a finalis em Sol. Glareanus, portanto, considerava que a finalis e phrasis $^{34}$ eram elementos subsidiários para a definição do modo de uma composição.

Zarlino, em seus escritos sobre os modos, utilizou como base o tratado de Glareanus. A principal diferença entre os dois teóricos é que Zarlino mudou, nas Dimontrationi harmoniche, a numeração dos modo. Para Zarlino, o modo 1 era aquele cuja espécie de oitava vai de Dó a Dó, a partir dele classificava-se os demais até o décimo-segundo modo. A razão para a mudança da ordem dos modos era o sistema de afinação defendido por Zarlino - afinação justa iniciada em Dó, de acordo com os ideais de Ptolomeu - (POWERS; WIERING, 2007, p. 16). Em sua teoria modal, Zarlino dá maior importância às consonâncias menores, como as terças, dessa forma ele indica como as principais consonâncias a serem utilizadas a terça e a quinta de cada modo, por exemplo no primeiro modo (da classificação de Zarlino) as principais notas seriam Dó, Mi e Sol.

Outro aspecto estudado por Zarlino, embora não seja uma inovação, é o ethos de cada modo (quadro 3.235). Wiering criou um quadro que mostra qual afeto Zarlino associa a cada modo. Galilei, embora não explicite os afetos de cada modo, reconhece que cada modo tem um afeto específico, que seriam os mesmos de Zarlino.

Como as diferenças nascem da diversidade entre as sete espécies de oitava de que dizem serem compostos os modos, quais são autênticos, quais são plagais, e porque são assim chamados, de onde nasce a tristeza e alegria que eles induzem nos ouvintes, em que notas dos modos devem se começar as peças, e em quais devem terminar, \& em quais notas devem ser feitas as cadências. Na quarta parte de Institutione harmoniche do mestre Gioseffo Zarlino, as encontrará com clareza, tudo o que se relaciona a essa nova prática de contraponto, tudo o que é necessário para essa profissão ${ }^{36}$ (GALILEI, 1584, p. 79).

Galilei considera que a teoria modal de Zarlino é a mais adequada para a música polifônica. No entanto, como pode ser visto na figura 3.25, ele relaciona as finalis com a ordem dos modos de

\footnotetext{
34 Segundo Powers e Wiering (2007, p. 14), o termo phrasis, como utilizado por Glareanus, significava as notas principais de cada modo que deviam ser utilizadas na construção melódica, de forma semelhante à repercussio, ou ao tenor.

${ }^{35}$ A nova organização dos modos foi proposta por Zarlino as Dimonstrationi harmoniche, publicada em 1571, o quadro 3.2 foi baseado na tradução de Vered Cohen do texto de 1558, portanto antes da nova organização.

36 ... come tal differentia nasca della diversità delle sette specie del Diapason delle qualle dicono esser composti i modi, quali siano gli autentici, \& qual'i placali, \& perche siano così detti, da che nascha la mestitia \& allegrezza ch'egl 'inducono negli ascoltanti, in quali corde del modo devono cominciare le cantilene, in quali debino finire, $\&$ in quali devono fare le cadentie. Nella quarta parte dell'Institutione harmoniche di miser Gioseffo Zarlino i troverete distintamente quanto pero a tiene a questa nuova prattica di contrapunto, tutto questo che intorno a ciò fa di mestiero (GALILEI, 1584, p. 79).
} 
Glareanus e, não, com a nova organização de Zarlino. Esse fato pode ser justificado tanto por uma negativa de Galilei em relação a inovação proposta por seu antigo professor, ou por um desconhecimento da nova distribuição.

\begin{tabular}{|c|c|c|}
\hline Modo & Descrição de Zarlino & Afeto \\
\hline 1 & Alquanto mesto & Algo triste \\
\hline 2 & Lagrimevole, humile, \& deprecativo & Lacrimoso, humilde e depreciativo \\
\hline 3 & Alquanto dura; natura di comovere al pianto & Duro, leva alguém às lágrimas \\
\hline 4 & $\begin{array}{l}\mathrm{Si} \text { accomoda maravigliosamente a parole, o } \\
\text { lamentevoli; che contengono tristezza, overo } \\
\text { lamentatione supplichevole }\end{array}$ & Lacrimoso, triste, lamentação suplicante \\
\hline 5 & Giocundo, modesto, \& dilettevole & jocoso, modesto e agradável \\
\hline 6 & Devoto, \& lagrimevole & devoto e choroso \\
\hline 7 & $\begin{array}{l}\text { Materie, che siano lascive, } \ldots \text { allegre, } \ldots \text { che significano } \\
\text { minaccie, perturbationi, \& ira }\end{array}$ & $\begin{array}{l}\text { Lascivo; alegre; expressa ameaça, } \\
\text { perturbação e raiva }\end{array}$ \\
\hline 8 & Allegrezza ... con somma giocondità, \& soavità mista & Prazer com grande alegria e doçura \\
\hline 9 & Materie allegre, dolci, soavi, \& sonore & Feliz, doce, suave e sonoro \\
\hline 10 & Non molto lontana da quella del secondo, \& del quarto & Não muito diferente dos modos 2 e 4 \\
\hline 11 & Atto alle danze... lascivo & apropriado para danças, lascivo \\
\hline 12 & cose amatorie, che contengono cose lamentevoli & $\begin{array}{l}\text { Textos sobre o amor que contenham } \\
\text { coisas tristes }\end{array}$ \\
\hline
\end{tabular}

Quadro 3.2 - Os afetos do modos de Zarlino (WIERING, 2001, pos. 376).

\subsubsection{Modo na música polifônica}

A tarefa de classificar o modo de uma composição polifônica não é simples. As principais dificuldades derivam do fato da teoria modal ter sido desenvolvida para a classificação de salmos e antífonas. Quando passamos para um sistema com mais de uma linha melódica, nem todas estarão dentro do âmbito do mesmo modo. Para dirimir essa questão, dois conceitos serão utilizados: o princípio do tenor, que determina o modo da peça polifônica de acordo com aquele utilizado pelo tenor; e a relação com o tipo tonal, que leva em consideração três características para determinar o 
tipo tonal de uma composição: armadura, clave e finalis (WIERING, 2001, pos. 337). Essas três categorias são o que Harold Powers (1981, p. 438) chama de tonal types (tipos tonais).

As três características das peças utilizadas na classificação dos tipos tonais são: armadura, indicado pela presença ou não de um bemol; o sistema de claves, indicado pela clave mais aguda normalmente é utilizada a do soprano indicada por c1 (do na primeira linha) ou g2 (sol na segunda linha) -; e pela finalis do modo. É importante perceber que cada modo pode ser representado por mais de um tipo tonal. Não se deve confundir os dois termos, tipo tonal não significa modo, mas um tipo tonal pode ser utilizado para representar um modo (POWERS, 1981, p. 443). Powers diferencia os termos utilizando as categorias antropológicas de ético e êmico:

Um tipo tonal é minimamente identificável por seus três marcadores e, portanto passível de ser observada objetivamente separada de seu contexto cultural ou musical; ele "científico", "ético". "Modo", por outro lado, está imbricado com a cultura musical do século XVI, não só como a doutrina viva da música da igreja e herança da Idade Média, mas como um constructo que foi experimentado por membros dessa cultura, de ambos pontos de vista, humanístico e tradicional; ele é completamente "êmico" e requer estudos em seus próprios termos, assim como em relação a qualquer música com a qual ele pode estar conectado $^{37}$ (POWERS, 1981, p. 439).

Frans Wiering (1998, p. 87-107) diferencia duas visões da teoria modal, uma interna e outra externa. $\mathrm{O}$ autor afirma que as duas visões podem ser encontradas no texto de Zarlino, Institutione harmoniche (1558), quando ele comenta acerca de composições que parecem estar no terceiro modo, por terem como finalis Mi (externa), mas dividem a oitava (interna), não como se espera (Mi-Si, Si-Mi), mas da forma como se divide a oitava do décimo modo (Mi-Lá, Lá-Mi). Zarlino considera, portanto, que a composição está no décimo modo, uma vez que a única coisa que ela tem em comum com o terceiro modo é a finalis (WIERING, 1998, p. 88).

Pode-se considerar que a interna seria teórica, referia-se à composição musical e à expressão do modo por toda a peça. A visão interna dos modos define os modos com base nas espécies intervalares. A visão externa dos modos preocupa-se com a classificação das composições, principalmente por meio da finalis. Segundo Wiering (1998, p. 96-97), os instrumentistas do século XVI poderiam realizar todas as suas atividades musicais apenas com a visão externa dos modos.

Wiering analisa a descrição da teoria modal de Galilei presente no Fronimo, como vimos acima, Galilei recomenda a leitura do tratado de Zarlino para que seu aluno compreenda as

\footnotetext{
${ }^{37} \mathrm{~A}$ tonal type is minimally identifiable by its three markers and thus objectively observable completely apart from its musical or cultural context; it is "scientific," it is "etic." "Mode" conversely is all bound up in sixteenth-century musical culture, not only as a living doctrine of the music of the church and a heritage from the Middle ages but also as a musical construct being experimented with by members of the culture, from both humanistic and traditional points of view; it is thoroughly "emic" and requires study on its own terms, as well as in relation to any music with which it may be connected (POWERS, 1981, p. 439).
} 
características da teoria modal. Wiering considera que nas páginas seguintes o alaudista desenvolve um método de classificação dos modos baseado na final e não na forma da composição. Na figura 3.25, pode-se ver como Galilei considerava as finalis de cada modo, tanto na voz do tenor como na do baixo, como a nota mais grave da espécie de quinta de cada modo. É interessante notar que, nos pares de modos que possuem a mesma finalis, eles são diferenciados pelo ambitus da voz do tenor (WIERING, 1998, p. 98). Wiering (1998, p. 99) sugere que essa visão externa dos modos poderia ser explicada pelo fato de Galilei utilizar a classificação do modo principalmente para escolher um prelúdio, ou peça similar, para a execução junto com uma composição com a mesma finalis.
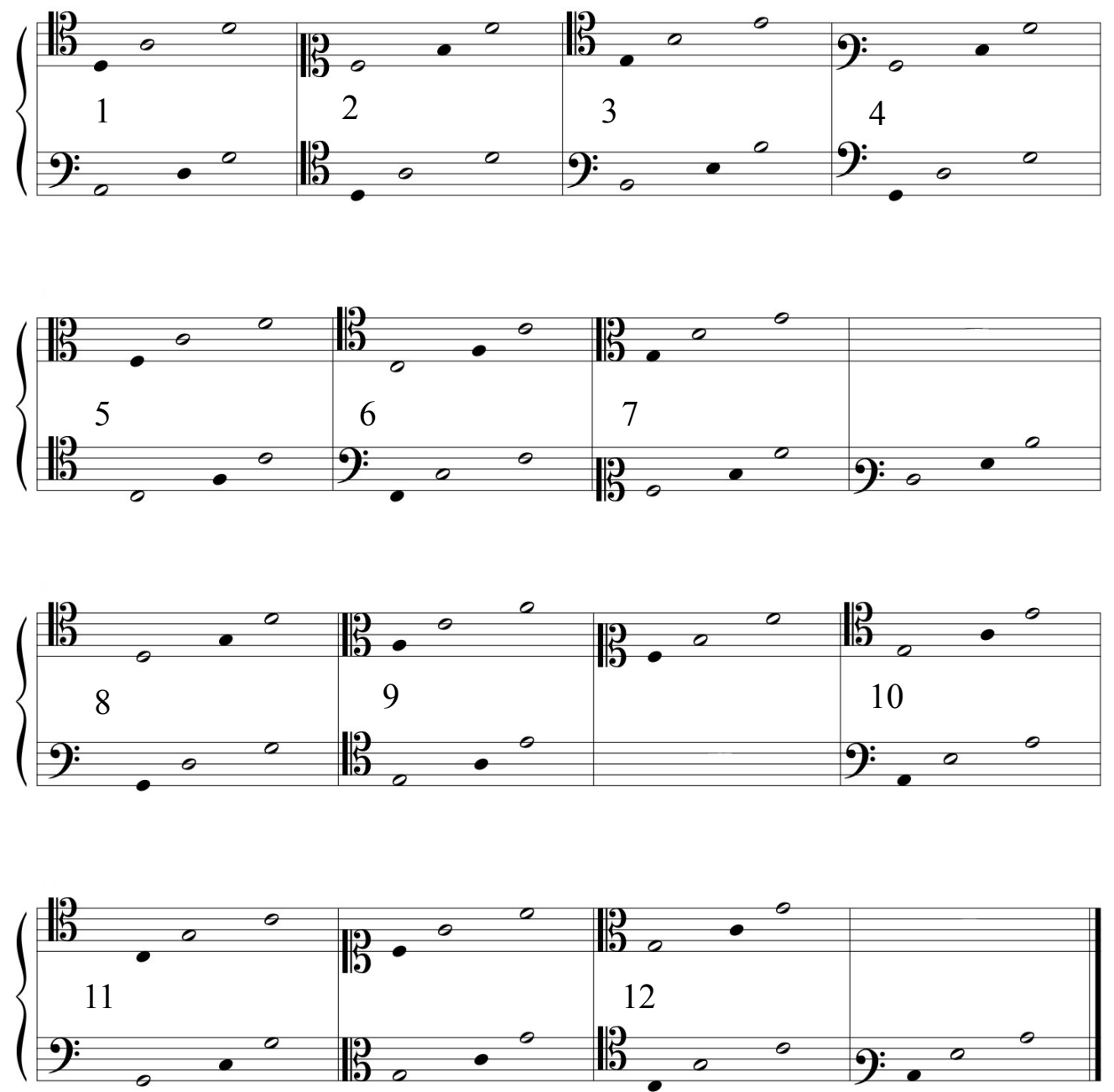

Figura 3.25 - As finalis de Galilei com bequadro (GALILEI, 1584, p. 90).

Anne Smith (2011, p.99) nos propõe alguns passos para determinar o modo de uma composição: primeiro devemos determinar se o modo está transposto, o que pode ser detectado pela presença de um bemol na armadura; em seguida examinamos o tenor para determinar a finalis, 
ambitus e o contorno melódico (espécies de quarta e quinta). Ela afirma que se ainda assim não pudermos determinar o modo, as outras vozes podem dar informações complementares.
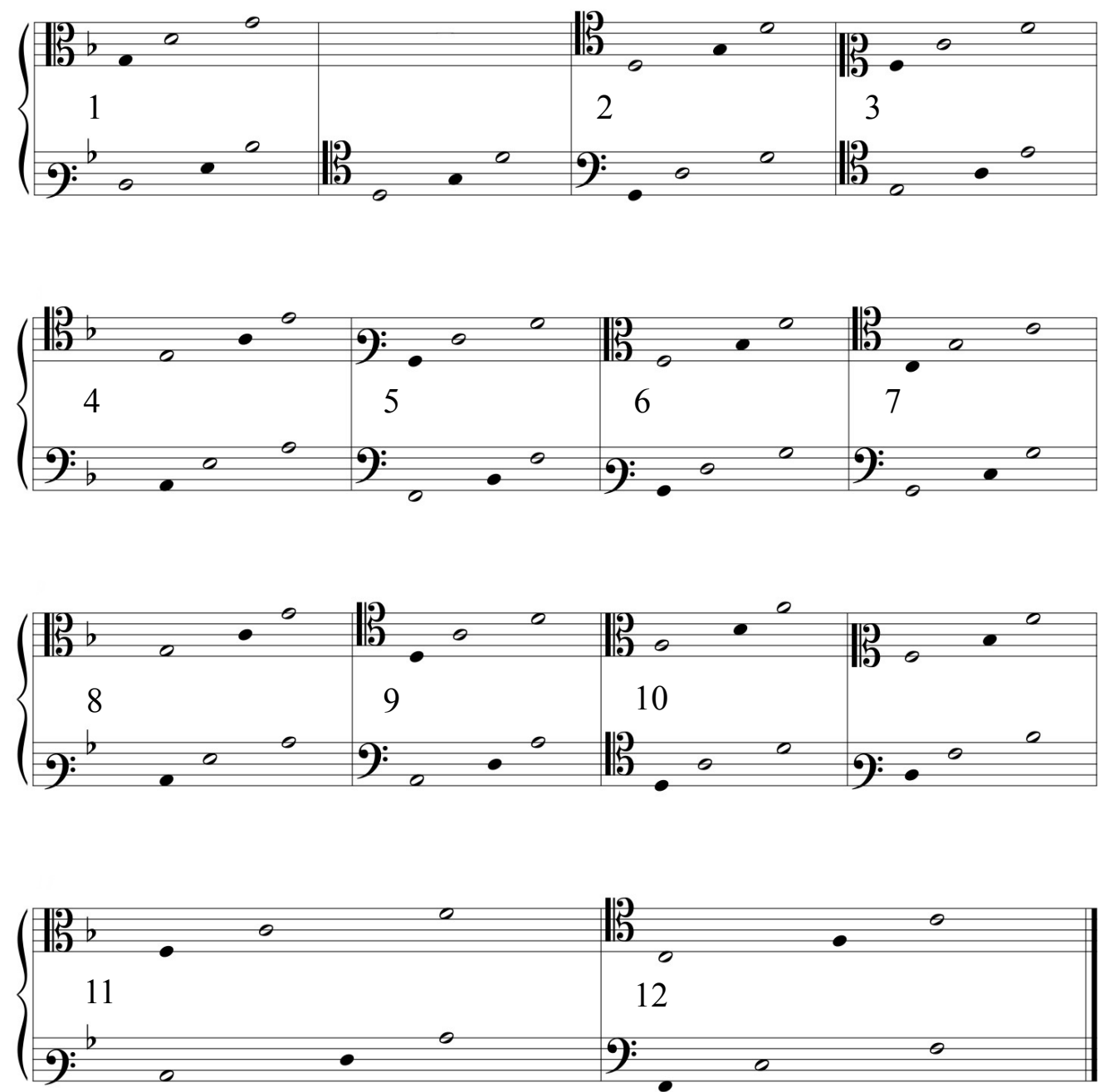

Figura 3.26 - As finalis de Galilei com bemol

(GALILEI, 1584, p. 90).

Para classificar o modo de uma entabulação, não podemos levar em consideração a clave para determinar o ambitus de uma voz. Deve-se cuidar da separação das vozes para determinar o ambitus por meio da análise do contorno melódico da voz. Galilei (1584, p. 91) afirma que nos modos autênticos a parte do baixo desce uma quinta abaixo da finalis e a parte do tenor não deve ir mais de uma terça acima de uma oitava da finalis. Nos modos plagais, o baixo não deve ir uma terça abaixo e o tenor deve ir pelo menos uma quinta acima da finalis. $\mathrm{O}$ ambitus das duas vozes pode ser visto na figura 3.25 e 3.26. Embora não haja indicação de signo na tablatura, não é difícil verificar se o Si bemol está sendo utilizado ou não pela análise da tablatura. É relevante saber se o Si bemol é parte da estrutura do modo ou apenas uma realização de ficta, para isso pode-se analisar o tipo tonal 
da peça, uma vez que a presença do bemol na armadura é evidência de que o modo foi transposto. Determinar a finalis tem um sentido especial nas tablaturas de alaúde, uma vez que ela pode ajudar a verificar qual a afinação do alaúde que era utilizado e como dito acima determinar se foi feita uma transposição. Acerca da transposição dos modos, Galilei $(1584$, p. 91) lembra que dos doze modos sete são transpostos uma quarta acima (primeiro, terceiro, quarto, sexto, oitavo, décimo e décimo primeiro) e cinco são transpostos uma quinta abaixo (segundo, quinto, sétimo, nono e décimo segundo).

Smith (2011) ressalta a importância de conhecermos o modo de uma peça, ao trazer a citação de Sancta Maria:

Esse assunto dos oito modos, naturais ou acidentais, é tão necessário que os músicos o entendam e saibam aplicar à música, que sem isso é impossível tocar sem cometer grandes erros, saindo a cada passo do modo e peregrinando por caminhos errados que ofendem gravemente os ouvidos, para remediar essa situação deve-se exercitar nessa matéria até que ela seja dominada (SANCTA MARIA apud SMITH, 2011, p. 101).

Wiering (1998, p. 104) ressalta que no século XVI a maior parte dos músicos tinha uma visão externa dos modos, no entanto alguns compositores teriam utilizado a visão interna do modo como forma de inspiração. O musicólogo recomenda, portanto, que uma análise do modo de uma peça deveria começar pelas características externas do modo. Somente após essa análise, devemos investigar se as características internas do modo têm alguma relevância na sua composição e em qual grau. Para as análises que serão desenvolvidas nessa pesquisa, seguiremos as recomendações de Wiering, analisando primeiro o tipo tonal das peças e apenas posteriormente uma análise das espécies de consonância para dirimir qualquer ambiguidade em relação ao modo da peça. 


\section{CAPÍTULO 4 - Análise: Io mi son giovinetta}

O madrigal foi composto por Domenico Ferrabosco. O texto utilizado no madrigal foi retirado do Decamerão de Giovanni Boccaccio. O madrigal foi publicado pela primeira vez em 1542 em uma coleção de madrigais de diversos autores. Esse é um dos madrigais mais famosos de Ferrabosco, além de aparecer em várias coleções de madrigais foram criadas as versões instrumentais de Galilei e Sweelink, além de uma messa parodia de Palestrina.

O madrigal pode ser dividido em duas partes. A primeira termina no compasso 11, com uma cadência na finalis, assim como a segunda parte. A primeira parte está composta em um estilo homofônico com pouca presença de imitações. A segunda começa com as vozes entrando alternadamente e o estilo imitativo prevalece. Essa estrutura é mantida por Galilei em sua entabulação como pode ser visto nas figuras A.1, A.2, A.3, A.4 A.5 e A.6, pode-se notar que mesmo nas ornamentações da segunda parte Galilei procura reafirmar o estilo imitativo.

\subsubsection{Cadências}

$\mathrm{Na}$ primeira parte da peça, podem ser encontradas três cadências: duas perfeitas e uma evitada. As duas perfeitas acontecem nos compassos 6-7 e 10-11. A do compasso 6-7 acontece em Lá. Nela encontram-se todas as características de uma cadência perfeita. Existe uma cláusula cantizans no cantus, uma tenorizans no tenor e uma bassizans no baixo. Entre o tenor e o cantus passa-se de uma consonância imperfeita para uma dissonância, dessa para outra consonância imperfeita e em seguida para a consonância perfeita mais próxima (de uma sexta maior para a oitava). Podemos observar na figura 4.1.

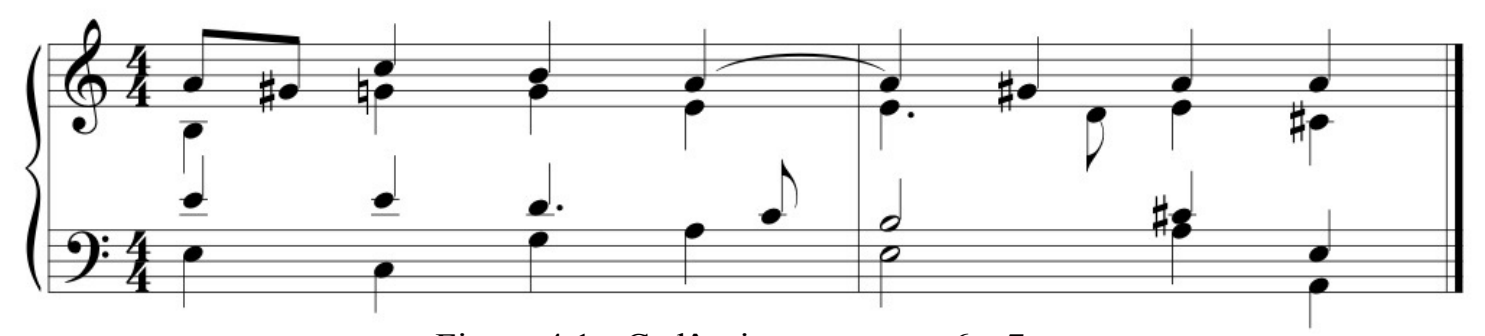

Figura 4.1 - Cadência compassos 6 e 7.

Galilei altera o contraponto original justamente nessa cadência. Na versão original a cadência perfeita pode ser claramente percebida, no entanto na versão de Galilei para que a relação entre tenor e cantus não é mantida a voz do tenor resolve para cima formando uma terça com o 
baixo. Essa forma de alteração da cadência original acontece repetidamente durante a peça. Pode-se considerar que, como foi afirmado no capítulo acerca do processo de entabulação, Galilei tenha optado por essa alteração para que a estrutura vertical fosse mais densa na resolução de algumas cadências.

Na cadência que termina a primeira parte da peça, pode-se perceber esse mesmo problema na relação do tenor com o cantus. Novamente encontram-se as estruturas de uma cadência perfeita no baixo, tenor e cantus. Na versão original, pode-se verificar que tenor e baixo acabam em uníssono, como prescrevem as utilizações das clausulas bassizans e tenorizans. Em sua entabulação Galilei leva a voz do tenor para um Fá sustenido, talvez por já considerar que a voz do baixo teria um papel mais importante na estrutura da cadência? O resultado, novamente, é a alteração do contraponto que proporciona uma estrutura vertical mais densa na resolução da cadência.

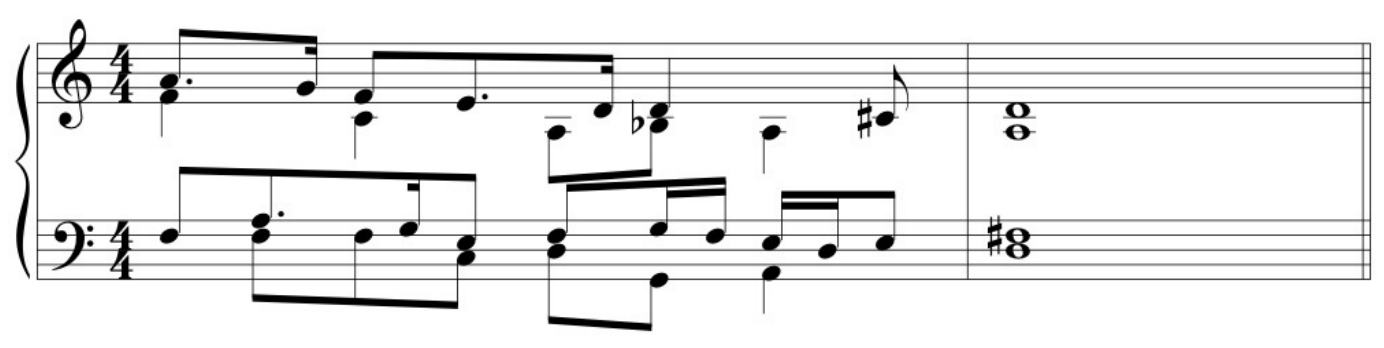

Figura 4.2 - Cadência compassos 10 e 11.

A cadência evitada que acontece nos compassos 3 e 4 se encaixa no primeiro tipo de cadência evitada citado no capítulo anterior, se for considerada a relação entre cantus e bassus. Em uma cadência perfeita o Fá deveria ser resolvido no Sol, mas em vez de uma segunda ascendente a voz caminha em uma segunda descendente. O tenor faz uma clausula tenorizans típica, embora ela esteja ornamentada. Nessa cadência, também existe uma alteração do contraponto original, além da ornamentação da voz do tenor, a parte do alto foi omitida. Essa última uma exceção à regra de Galilei que afirma que em peças de até quatro vozes nenhuma delas deve ser suprimida.

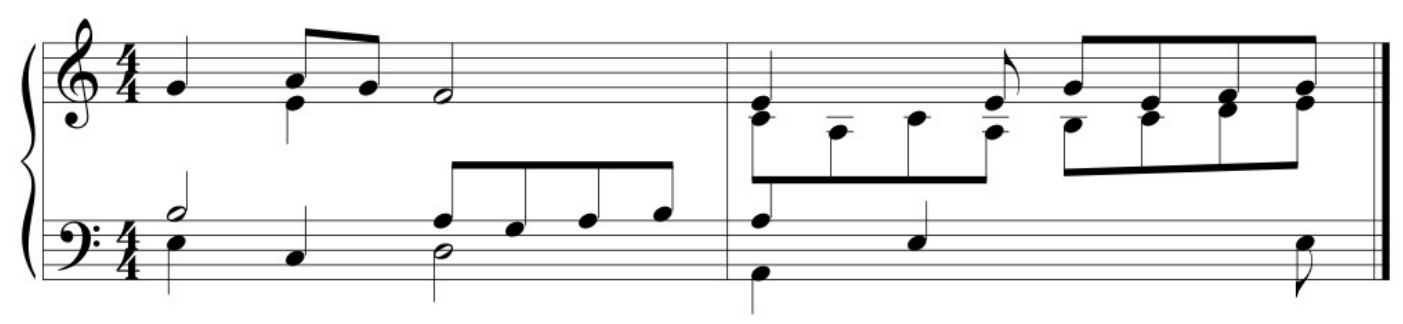

Figura 4.3 - Cadência compassos 3 e 4. 
Na segunda parte, podem ser encontradas mais três cadências em Lá. As três são cadências perfeitas e estão transcritas exatamente como na versão original. As duas primeiras têm a clausula cantizans no cantus, a tenorizans no tenor e a bassizans no baixo. A terceira difere das anteriores, pela clausula cantizans que está no alto em vez de no cantus. Das outras quatro cadências da segunda parte duas são em Mi, uma em Fá e a última em Ré. As duas cadências em Mi são cadências frígias entre as vozes do baixo e alto (compassos 14-15 e 19-20). As outras duas cadências são as que Galilei faz as maiores diminuições. Nas duas, percebe-se a mesma situação das cadências perfeitas da primeira parte, Galilei altera a resolução da voz do tenor, fazendo com que a clausula tenorizans resolva para cima, o que resulta em uma textura vertical mais complexa. Talvez uma evidência de uma concepção estrutural diferente do contraponto, em que a relação entre baixo e cantus é mais importante que a entre tenor e cantus.

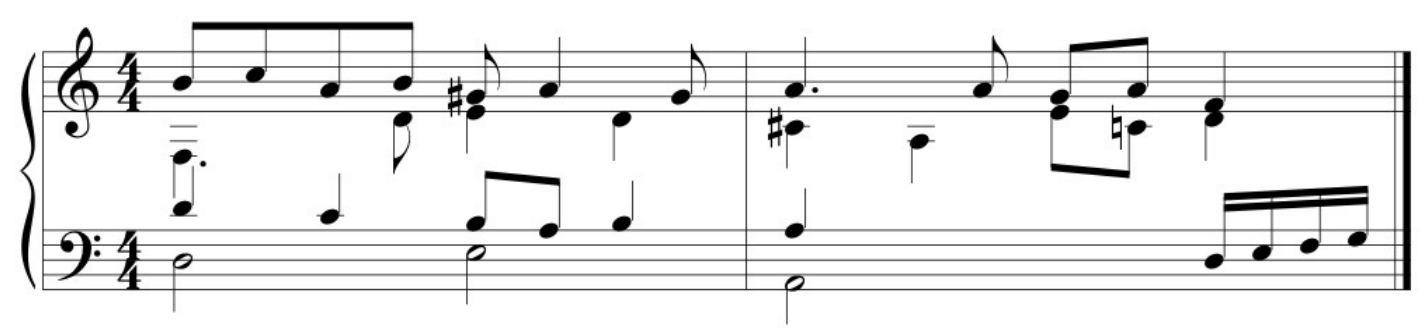

Figura 4.4 - Cadência compassos 16 e17.

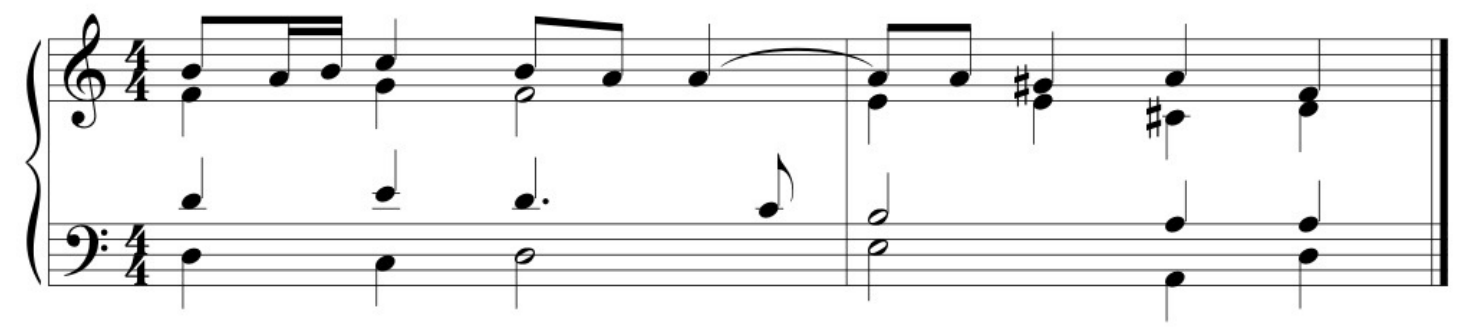

Figura 4.5 - Cadência compassos 23 e 24.

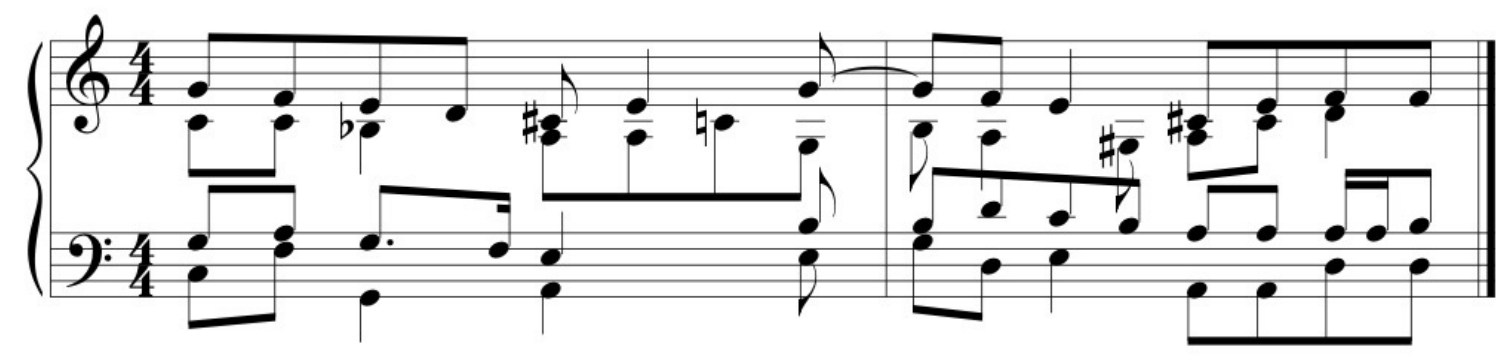

Figura 4.6 - Cadência compassos 31 e 32. 


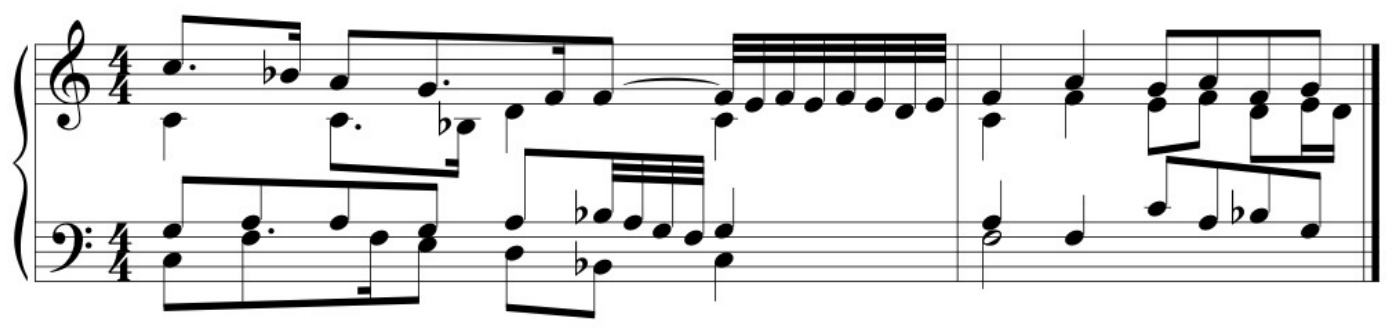

Figura 4.7 - Cadência compassos 27 e 28.

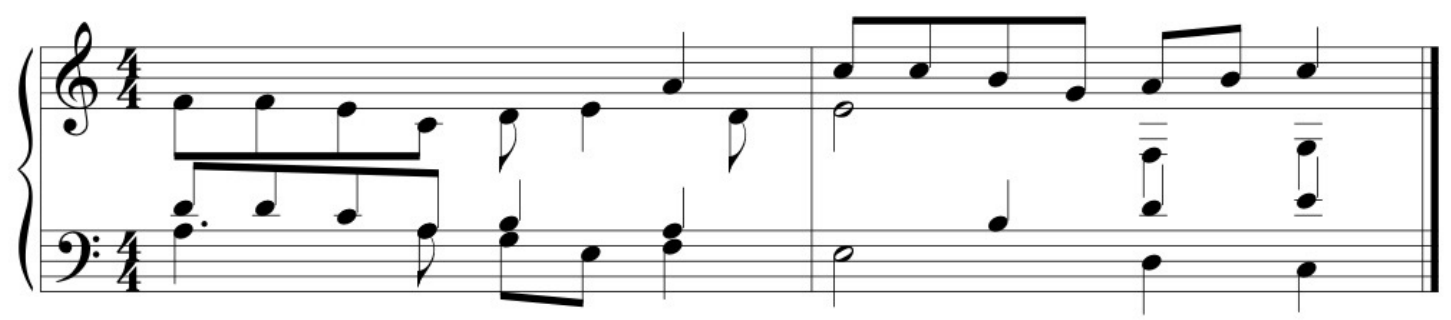

Figura 4.8 - Cadência compassos 14 e 15.

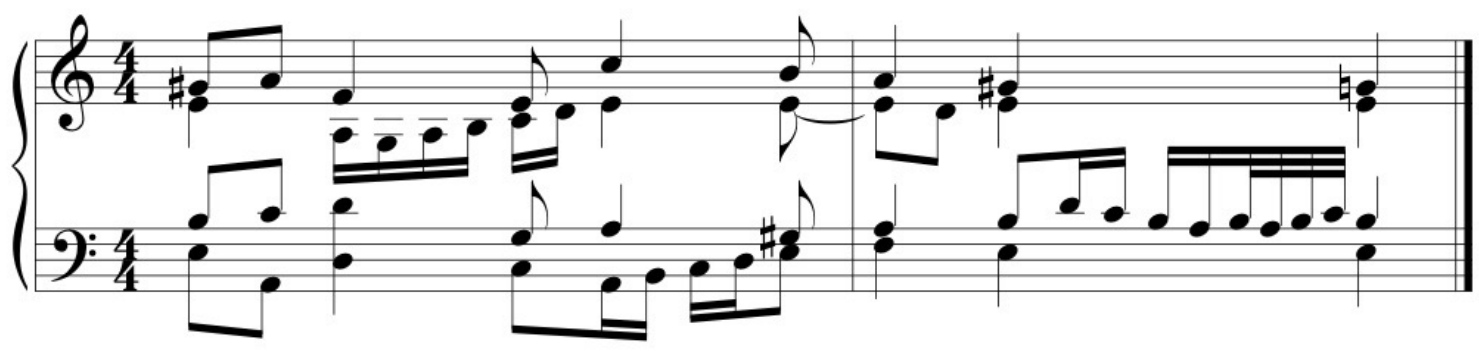

Figura 4.9 - Cadência compassos 19 e 20.

As notas escolhidas por Ferrabosco e Galilei para realizar as cadências estão de acordo com a teoria proposta por Zarlino. Segundo este autor, as cadências desse modo devem ocorrer nas notas Ré, Fá e Lá. Quase todas as cadências da peça acontecem nessas notas que Zarlino qualificava como regulares, as demais cadências seriam irregulares (ZARLINO, 1983, p. 55). Portanto, as cadências em Mi seriam classificadas como irregulares.

\subsubsection{Modo}

A análise do tipo tonal da canção original tem o Sol 2 como finalis, tanto do tenor quanto do baixo. As claves utilizadas foram G2, C2, C3 e F3, claves altas. A armadura de clave é Si bemol. Portanto o tipo tonal do original vocal é (b G2 Sol). Esse tipo tonal está de acordo com o que Powers (1981, p. 444) encontrou ao analisar o ciclo de madrigais de Cipriano de Rore para o 
primeiro modo. $\mathrm{O}$ fato de estar notado em claves altas e com bemol na armadura indica que o modo está transposto uma quarta acima, o que está de acordo com a transposição prevista por Galilei para esse modo.

\subsubsection{Novo Método analítico de tipos tonais a partir de uma entabulação}

A análise do tipo tonal da entabulação feita por Galilei também está de acordo com a indicação do primeiro modo para a peça. A finalis da peça é Ré, embora na entabulação ela apareça apenas nas vozes do cantus e do baixo, o tenor na entabulação termina em Fá sustenido. Pode-se considerar que não há bemol na armadura, embora não exista armadura de clave em uma tablatura, todas as ocorrências de Si bemol na entabulação são realizações de ficta. As tablaturas também não apresentam clave, mas pode-se verificar, nos exemplos de finalis de Galilei, que a nota indicada como finalis do primo tuono em cantus durus para o baixo é o Ré 2, a mesma da entabulação, que Galilei nota na clave F4, portanto pode-se considerar que foram utilizadas chiavi naturali. O tipo tonal resultaria então em (

No entanto, esse tipo tonal pode se adequar a mais de um modo. Segundo o tratado de Galilei, o madrigal pode estar escrito no primo tuono per bequadro, ou então no nono tuono per bemolle, uma vez que esses são os dois touni que possuem a finalis em Ré. Embora a ausência de bemol na armadura indique que ela está no primo tuono, para dirimir qualquer dúvida acerca de qual o tuono da peça, é necessário analisar outras características como o ambitus, as espécies de quinta e quarta utilizadas e a repercussio. O ambitus do tenor é do Ré 2 ao Mi 3, o que se encaixa com o esperado para o primeiro tuono. As demais características também se enquadram no primeiro tuono, espécie de quinta Ré-Lá e a repercussio em Lá.

Além da tabela com as finalis oferecida por Galilei, temos no Fronimo 24 ricercari, um para cada tuono (12 com bequadro e 12 com bemol). Uma análise dos ricercari demonstra que a estrutura do ricercar del primo tuono per bequadro é bastante semelhante em relação as cadências utilizadas, o que não acontece com o ricercar del nono tuono. A comparação com a partitura original também parece corroborar essa análise, nela a finalis é Sol e a estrutura cadencial também é a esperada para o primo tuono transposto (Sol, Si bemol e Ré). 


\subsubsection{Dissonâncias}

O uso de dissonâncias na peça apresenta algumas diferenças entre o original vocal e a entabulação de Galilei. A maior parte delas advém das diminuições feitas pelo alaudista. No entanto, poucas cadências adicionadas por Galilei trazem o seu novo tratamento de dissonâncias. Elas acontecem na metade do segundo tempo do compasso 16; no início do quarto tempo do compasso 21; primeiro tempo do compasso 22; na metade do primeiro tempo do compasso 24 . Tanto a do compasso 16 quanto a do compasso 21 referem-se ao mesmo caso citado no capítulo anterior: podem-se realizar dissonâncias simultâneas por meio de suspensão (fig. 4.10, ex. 6). As duas seguintes também são muito parecidas. Galilei repete a nota que estava em suspensão, o que parece a descrição do exemplo de inovação no tratamento de dissonâncias três: por progressão para uma nova dissonância.

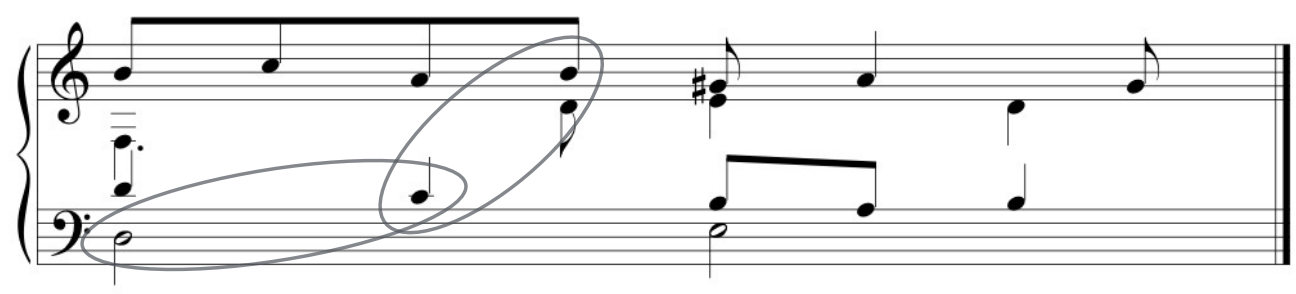

Figura 4.10 - Exemplo dissonância compasso 16.

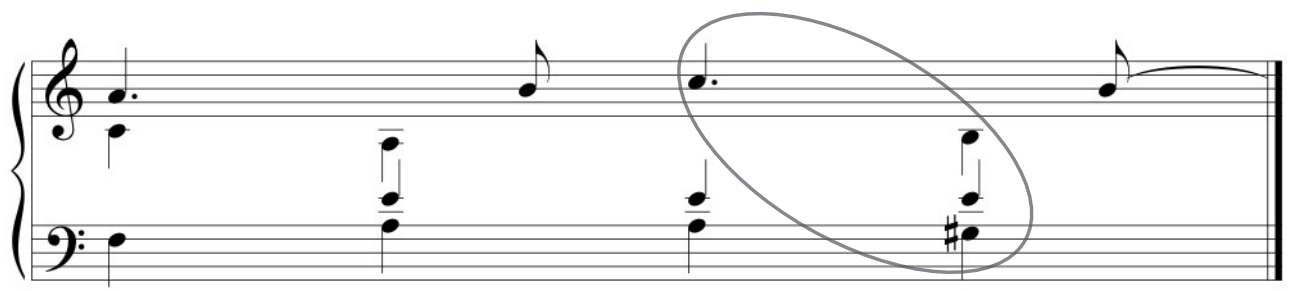

Figura 4.11 - Exemplo dissonância compasso 21.

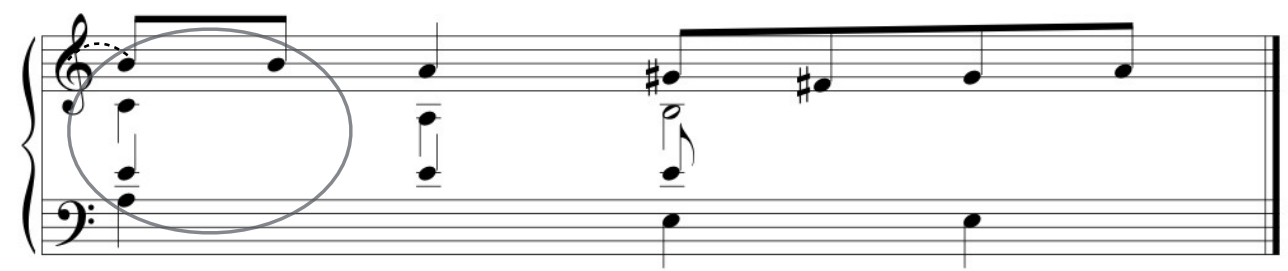

Figura 4.12 - Exemplo dissonância compasso 22. 


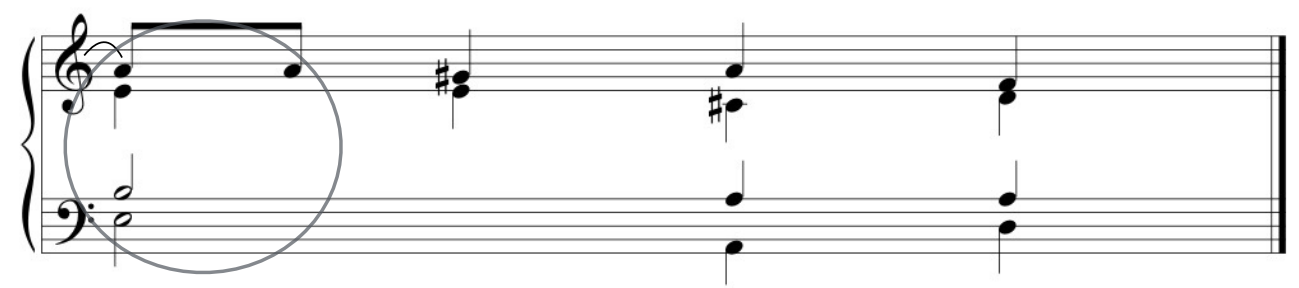

Figura 4.13 - Exemplo dissonância compasso 24.

Existem outras dissonâncias que se adequam às inovações de Galilei, mas essas já estavam presentes no original vocal de Ferrabosco. Elas acontecem nos compassos 6, 18, 23 e 34. As que acontecem nos compassos 6, 18 e 23 referem-se ao exemplo número sete (figuras 4.11 e 4.12): podem-se realizar dissonâncias, sem suspensão nos tempos fortes, desde que a resolução seja a comum. As dissonâncias que acontecem no compasso 34 são contempladas pelo primeiro exemplo: em uma sequência de quatro semínimas duas podem ser dissonantes em qualquer posição. No caso indicado, acontecem uma sequência de colcheias e semicolcheias, mas, por analogia pode-se considerar que a prescrição se aplica. A diferença entre a data em que Galilei escreve o seu tratado de contraponto e a da composição de Ferrabosco indica que a prática possivelmente acontecia décadas antes de Galilei condensá-las em seu tratado.

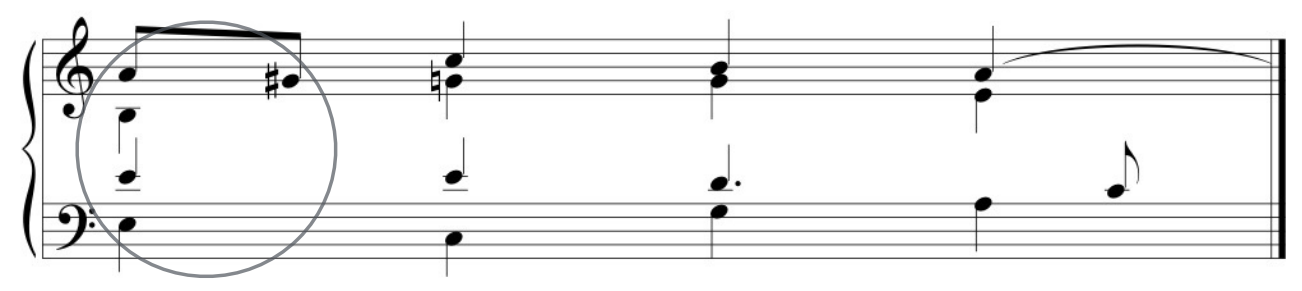

Figura 4.14 - Exemplo dissonância compasso 6.

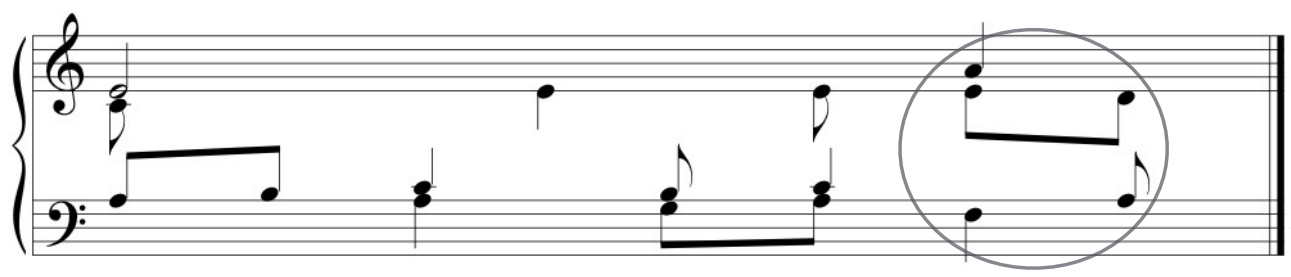

Figura 4.15 - Exemplo dissonância compasso 18.

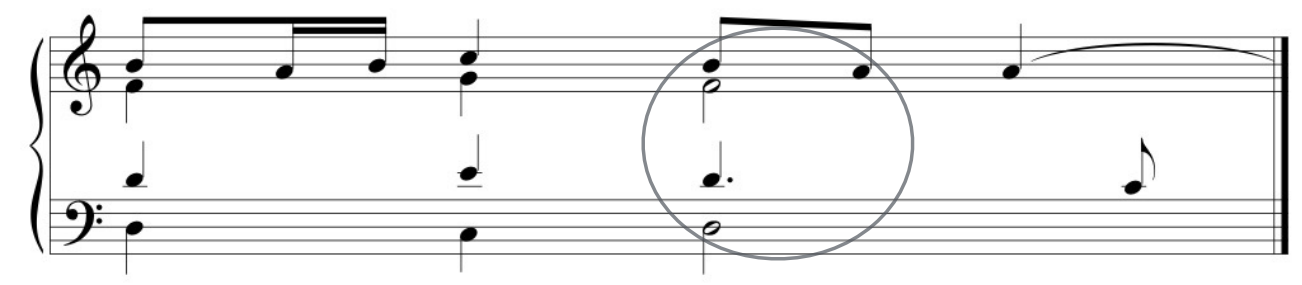

Figura 4.16 - Exemplo dissonância compasso 23. 


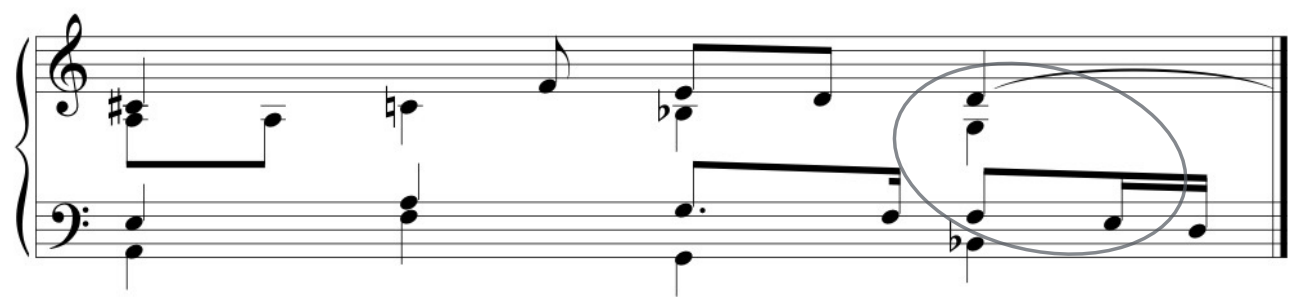

Figura 4.17 - Exemplo dissonância compasso 34.

As demais dissonâncias respeitam as regras de uso presentes nos tratados da maioria dos teóricos do período. Quanto ao número de dissonâncias acrescentado por Galilei, o aumento é significativo. Galilei quase dobra o número de dissonâncias usadas, boa parte delas são o resultado de diminuições e outras são utilizadas para reforçar a estrutura das cadências, além daquelas que compõe os clichês cadenciais da época. Galilei acrescenta duas dissonâncias no início do compasso 22, momento em que as vozes cantam spine (espinho). Possivelmente Galilei buscava compensar a ausência do texto com as dissonâncias, que como vimos acima se encaixavam em um dos casos apontados como inovações do alaudista.

\subsubsection{Adaptações do contraponto vocal ao meio instrumental}

A análise das alterações feitas por Galilei será feita em duas modalidades: a primeira considera os ornamentos colocados pelo alaudista; a segunda se concentra nas alterações realizadas como adaptação para execução instrumental.

Apesar de prescrever o respeito ao contraponto original, a entabulação realizada por Galilei não é uma simples transcrição do original vocal, a utilização de ornamentos, embora em muitos casos apenas o preenchimento melódico de intervalos, também pode ser considerada como uma intervenção criativas do alaudista no processo, como Vaccaro afirma ser o caso de Albert de Rippe. As primeiras passagens ornamentadas que parecem ter alguma função estrutural são as que aparecem nos compassos 3 e 20. A ornamentação do compasso 3 (figuras 4.19 e 4.20) pode ser classificada como uma diagonal. Esse trecho, originalmente escrito à quatro vozes (figura 4.18), foi reduzido na entabulação para três vozes, a passagem composta por Galilei começaria no Si 2 do tenor e terminaria com o movimento do Si 2 novamente resolvendo em Dó 3 e Lá 2, que traz de volta a polifonia à 4 vozes. Provavelmente Galilei fez uso desse recurso porque a execução das quatro vozes no alaúde, mas ainda assim o recurso parece ter sido utilizado com objetivo diferente do descrito por Vaccaro. 
A ornamentação do compasso 20 é muito similar ao que Vaccaro descreve como a origem das diagonais, Galilei, no entanto, é cuidadoso para que toda a diminuição aconteça no âmbito do tenor, dessa forma ele não perturba a estrutura polifônica da peça. Diferente da ornamentação do compasso 3, a função desse ornamento pode ser proporcionar um élan para a próxima frase, ou seja nesse momento a intensão do alaudista não foi de resolver um problema de execução, mas de gerar uma continuidade horizontal.

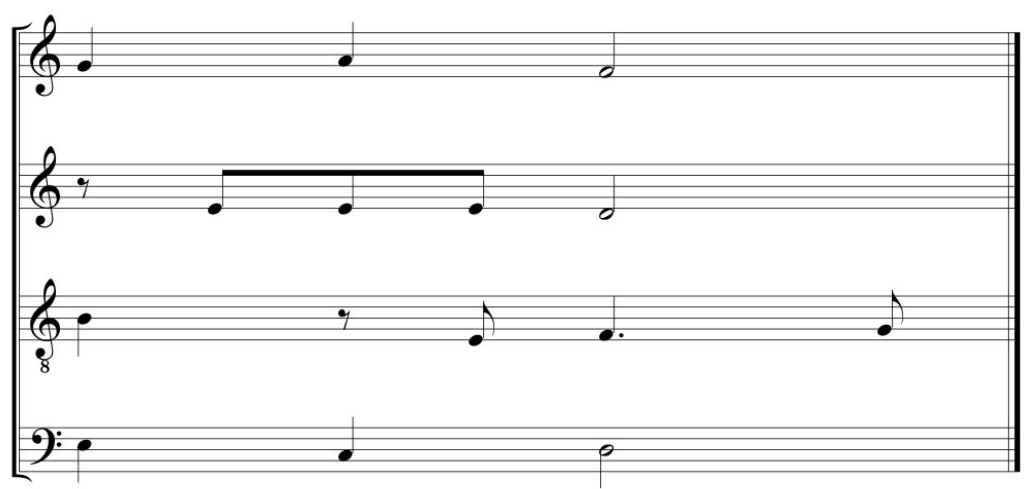

Figura 4.18 - Ornamentação compasso 3 (grade).

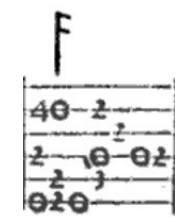

Figura 4.19 - Ornamentação compasso 3 (entabulação).

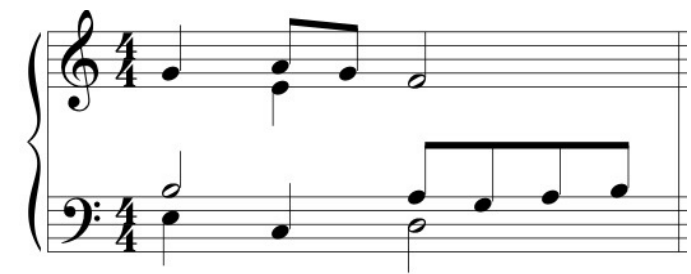

Figura 4.20 - Ornamentação compasso 3 (transcrição da entabulação).

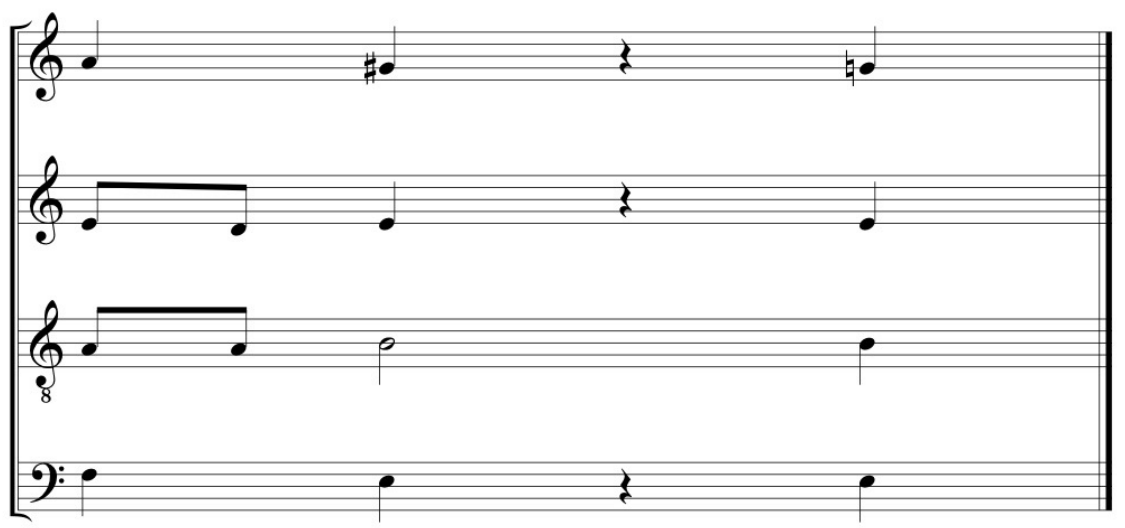

Figura 4.21 - Ornamentação compasso 20 (grade). 


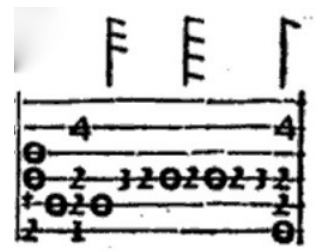

Figura 4.22 - Ornamentação compasso 20 (entabulação).

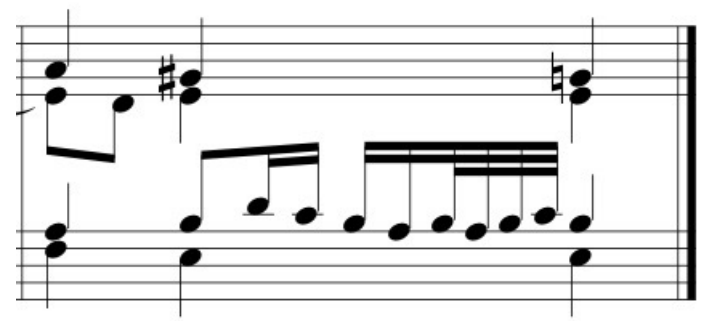

Figura 4.23 - Ornamentação compasso 20 (transcrição da entabulação).

As duas outras ornamentações que também têm relevância semelhante a anterior na entabulação acontecem nos compassos 27 e 35 . Ambas são diminuições típicas da música para alaúde do período. Nesses casos elas marcam as duas cadências da próximas ao fim da entabulação, uma em Fá e outra em Ré, esta a última cadência da peça. Como foi visto acima na análise das cadências, estas são notas cadenciais que Zarlino considerava regulares. Galilei provavelmente considerava que essas cadências eram importantes porque foram as únicas que receberam esse tratamento.

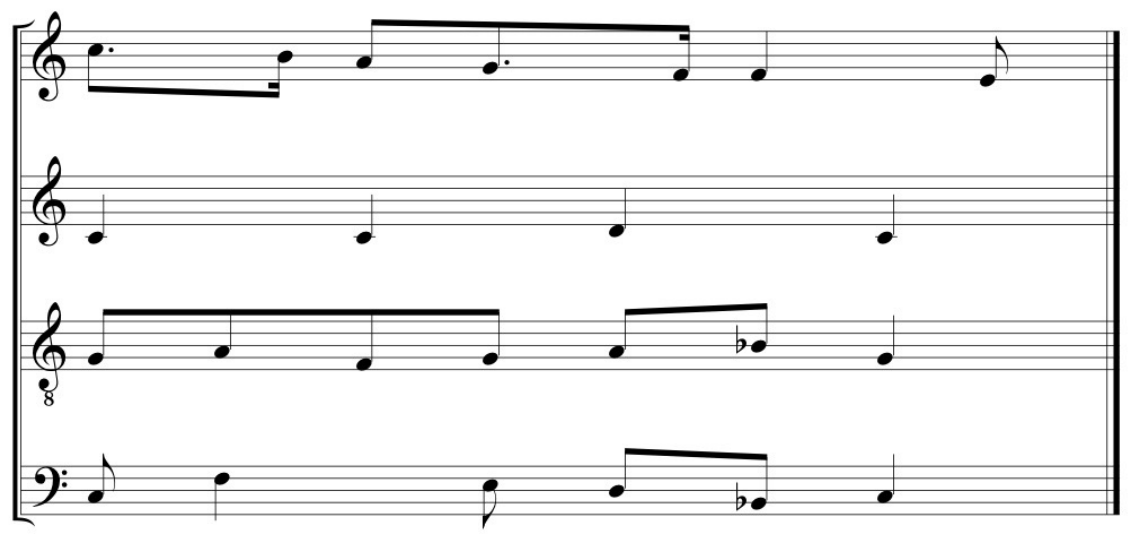

Figura 4.24 - Ornamentação compasso 27 (grade).

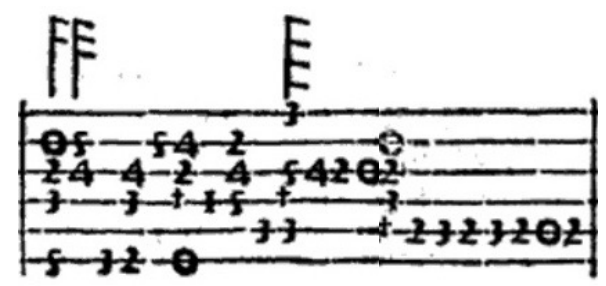

Figura 4.25 - Ornamentação compasso 27 (entabulação). 


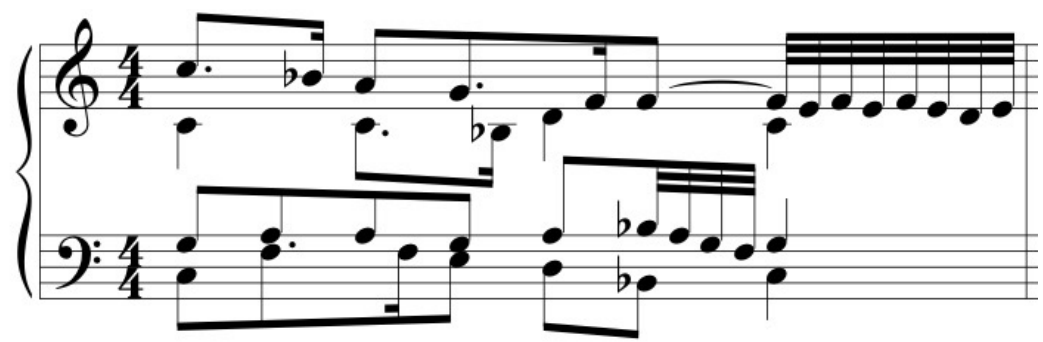

Figura 4.26 - Ornamentação compasso 27 (transcrição da entabulação).

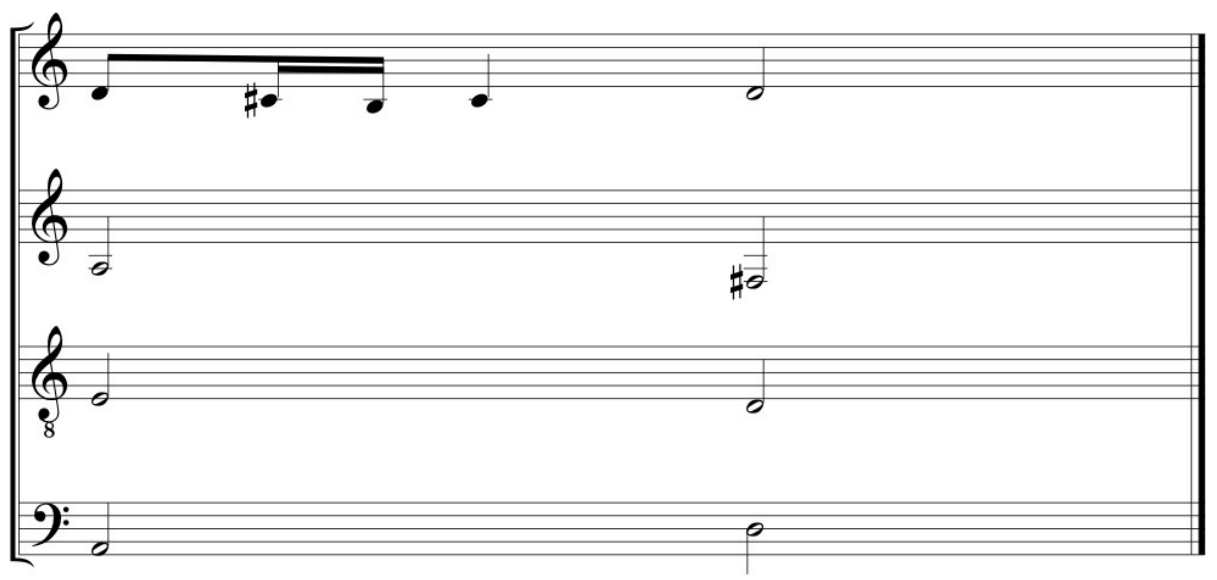

Figura 4.27 - Ornamentação compasso 35 (grade).

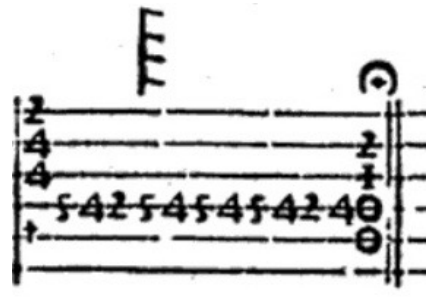

Figura 4.28 - Ornamentação compasso 35 (entabulação).

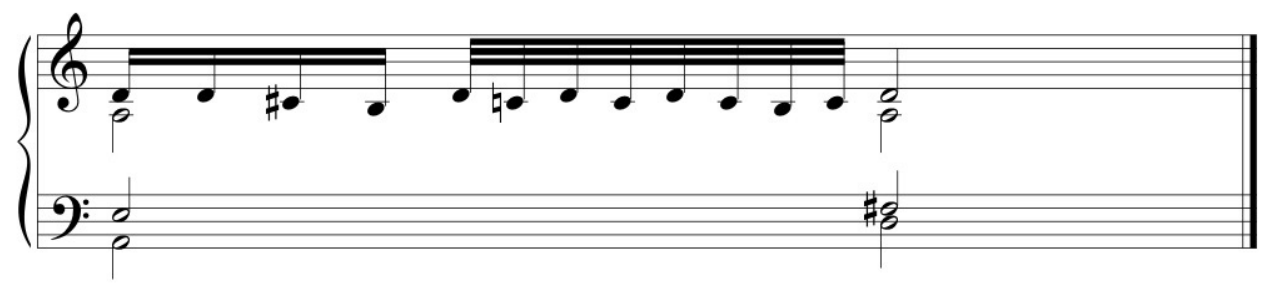

Figura 4.29 - Ornamentação compasso 35 (transcrição da entabulação).

Quanto às alterações relacionadas à execução instrumental, as mais óbvias são as notas oitavadas, porque não podem ser executadas em um alaúde de seis ordens. No caso dessa peça, são as ocorrências da nota Fá 1, muito grave para ser executada. A solução de Galilei corresponde ao que ele afirma ao explicar as poste para Eumatio. A análise dessas ocorrências é uma boa 
oportunidade para precisar o que Galilei entende por peças que usam essa nota apenas de passagem ou em cadências. Fá é uma das possibilidades de cadência, e, com efeito, uma das cadências acontece em Fá. A primeira vez em que é necessário o uso da nota oitavada (compasso 10), não há nenhuma alteração decorrente dela, com exceção de uma pequena diminuição na voz do tenor, não existem diferenças em relação ao original. A segunda ocorrência (compasso 28) é a cadência que resolve em Fá. Nessa, como em outras cadências dessa mesma peça, Galilei altera a resolução composta por Ferrabosco. Os intervalos, em relação ao baixo, no original são os seguintes: oitava com o tenor, décima com o alto e décima quinta com o cantus, na entabulação de Galilei encontrase: terça com o tenor, quinta com o alto e oitava como cantus. Pode-se perceber que a estrutura vertical é mais rica na versão de Galilei, embora o âmbito seja reduzido. Caso as alterações não tivessem sido realizadas, a diferença seria um uníssono entre tenor e baixo. Nos últimos seis compassos, o Fá 1 é oitavado algumas vezes, dessas, as três do compasso 30 levam Galilei à mudar a voz do tenor, do Fá 2 que seria uníssono com o baixo, para o Lá 2, novamente cia uma terça entre baixo e tenor. A ocorrência no compasso 31 é a mais curiosa, uma vez que o Fá oitavado gera um salto melódico de sétima, pouco usual e até proibido por alguns teóricos do período. Quando um trecho semelhante acontece no compasso 33, a solução adotada por Galilei é semelhante à anterior, ele altera a voz do Tenor em uma terça ascendente. Assim como no compasso 31, ao oitavar o Fá 1, Galilei gera um intervalo melódico de sétima no baixo, no compasso 34.

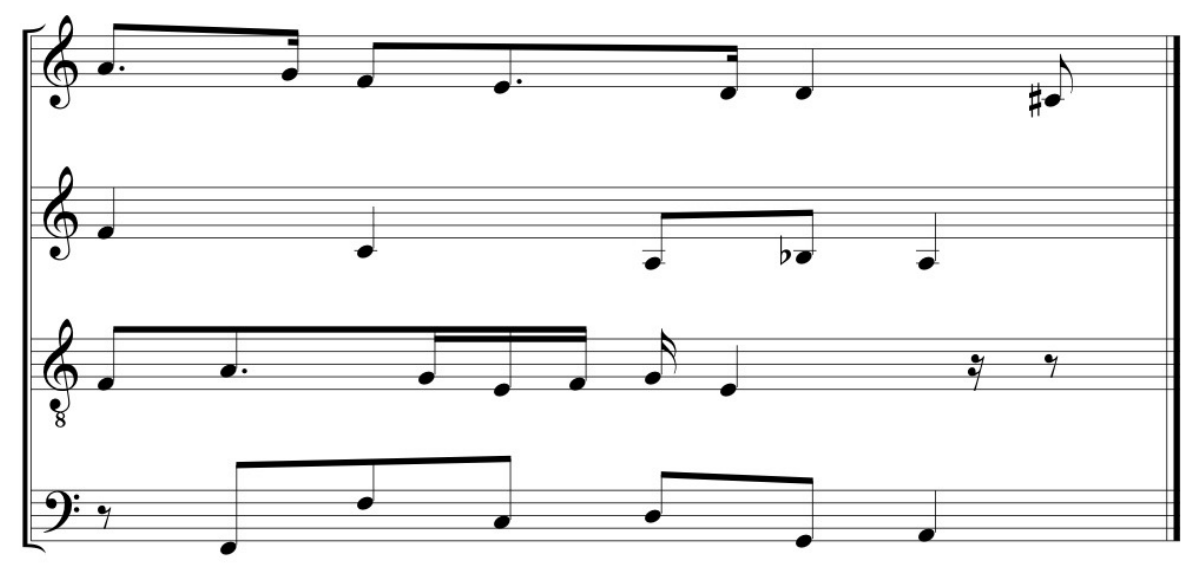

Figura 4.30 - Nota do baixo oitavada compasso 10 (grade).

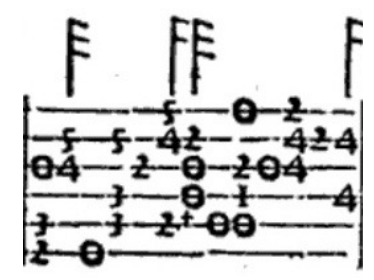

Figura 4.31 - Nota do baixo oitavada compasso 10 (entabulação). 


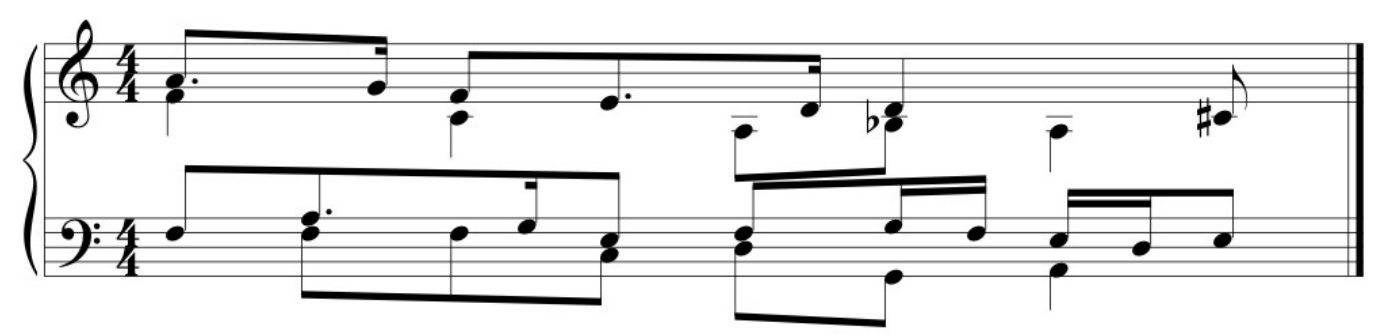

Figura 4.32 - Nota do baixo oitavada compasso 10 (transcrição da entabulação).

À primeira vista, as duas diminuições que Galilei faz no compasso 12 parecem ser apenas uma, como as diagonais descritas por Vaccaro (1981, p. 198). Uma análise mais cuidadosa, no entanto, mostra que na verdade eles são as entradas das vozes do cantus e do alto ornamentadas e em imitação. $\mathrm{O}$ alto entra na finalis e em seguida o cantus repete a mesma diminuição uma quinta acima. Como pode ser visto na figura 4.34 e 4.35 , a entrada em imitação pode ser facilmente percebida na versão transcrita em notação moderna, mas na versão em tablatura pode-se perceber como essa interpretação pode ser ambígua.

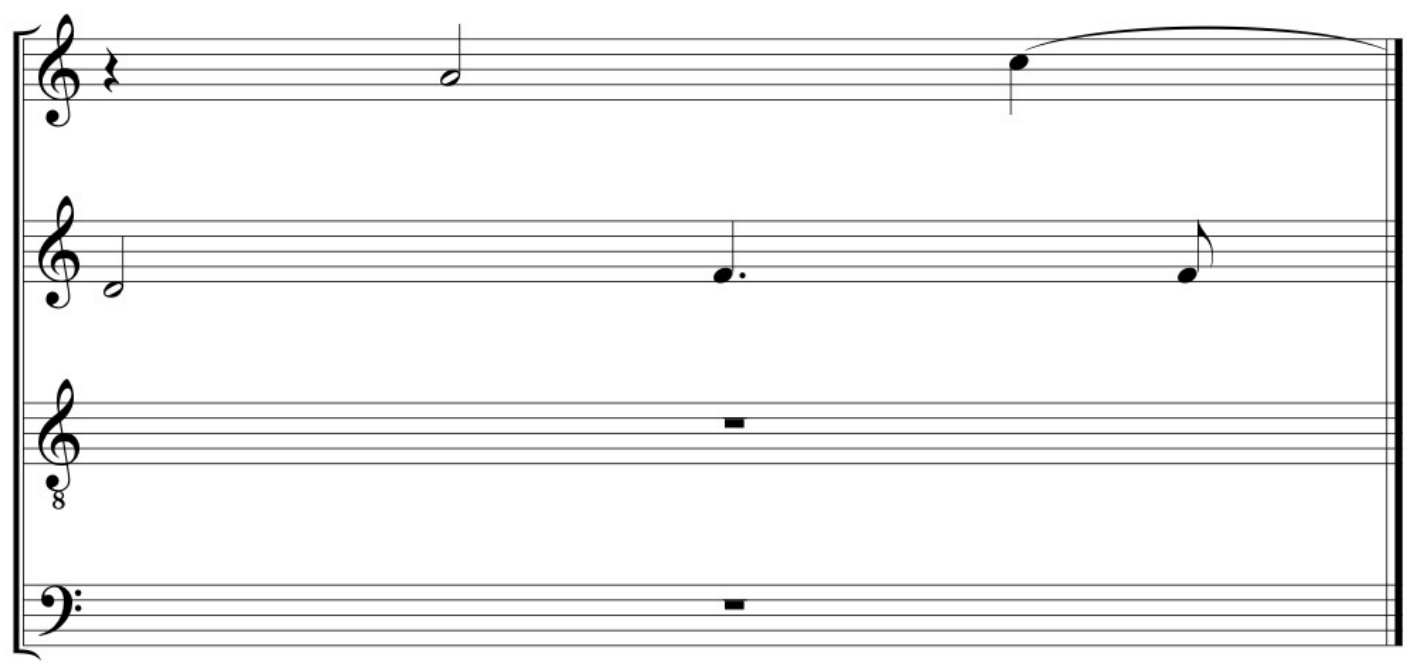

Figura 4.33 - Ornamentação compasso 12 (grade).

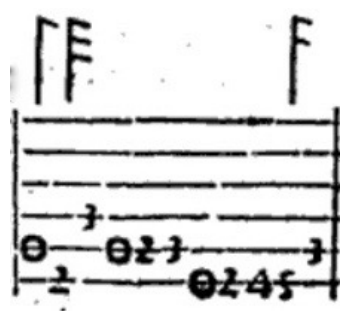

Figura 4.34 - Ornamentação compasso 12 (entabulação). 


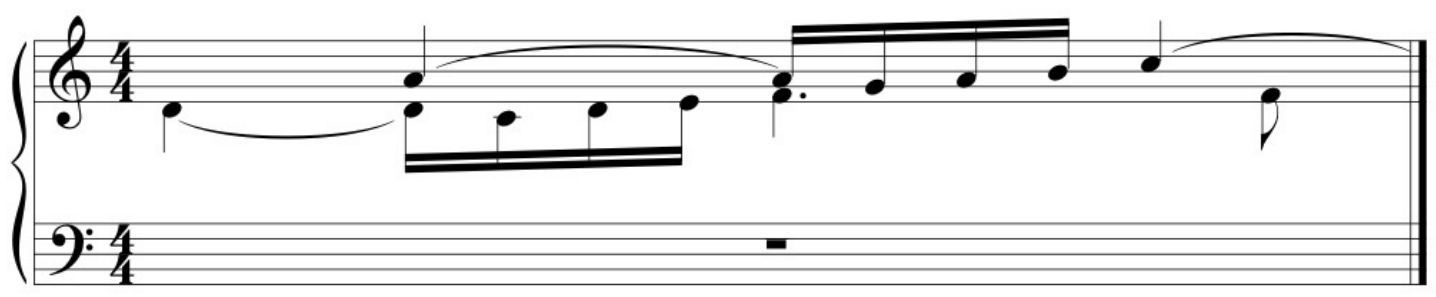

Figura 4.35 - Ornamentação compasso 12.

Além de utilizar, como afirmado acima, diminuições para proporcionar continuidade nos momentos em que existem pausas verticais em todas as vozes, Galilei omite, ou prolonga algumas notas provavelmente para que a execução ao alaúde seja realizada com mais graça e leveza. A maior parte das notas, não é de fato omitida, mas substituída por uma de maior duração. Isso ocorre com notas repetidas, por exemplo, no compasso 19, o segundo tempo do original de Ferrabosco na voz do baixo existem duas colcheias, na versão de Galilei elas foram substituídas por uma semínima. Muito provavelmente a opção por esse tipo de alteração não foi técnica, uma vez que as notas repetidas podem ser executadas sem acrescentar dificuldade à entabulação. Em outros locais Galilei faz a alteração contrária, transforma uma nota longa em uma mais curta. Existe um exemplo desse tipo no compasso 22 na voz do baixo, o primeiro tempo da voz é uma mínima, Galilei a transforma em uma semínima, muito provavelmente porque a voz do alto faz um uníssono com o baixo e para que a voz do tenor continue a soar é necessário executar as duas na mesma posição.

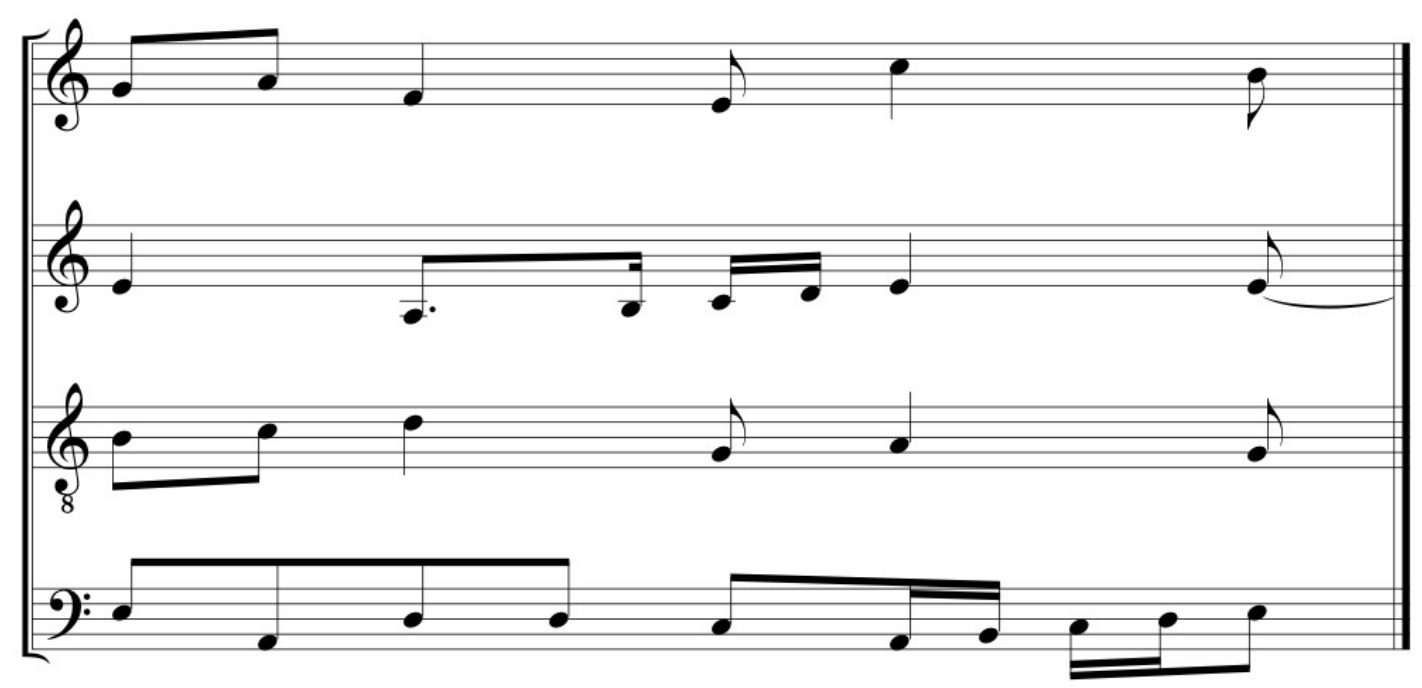

Figura 4.36 - Exemplo de nota omitida compasso 19 (grade). 


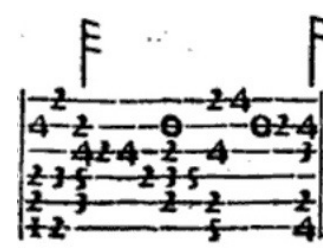

Figura 4.37 - Exemplo de nota omitida compasso 19 (entabulação).

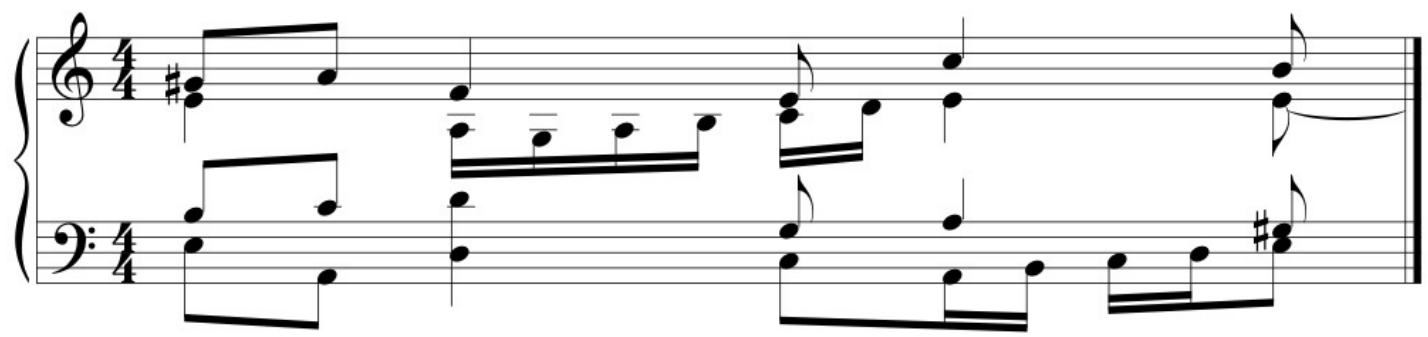

Figura 4.38 - Exemplo de nota omitida compasso 19 (transcrição da entabulação).

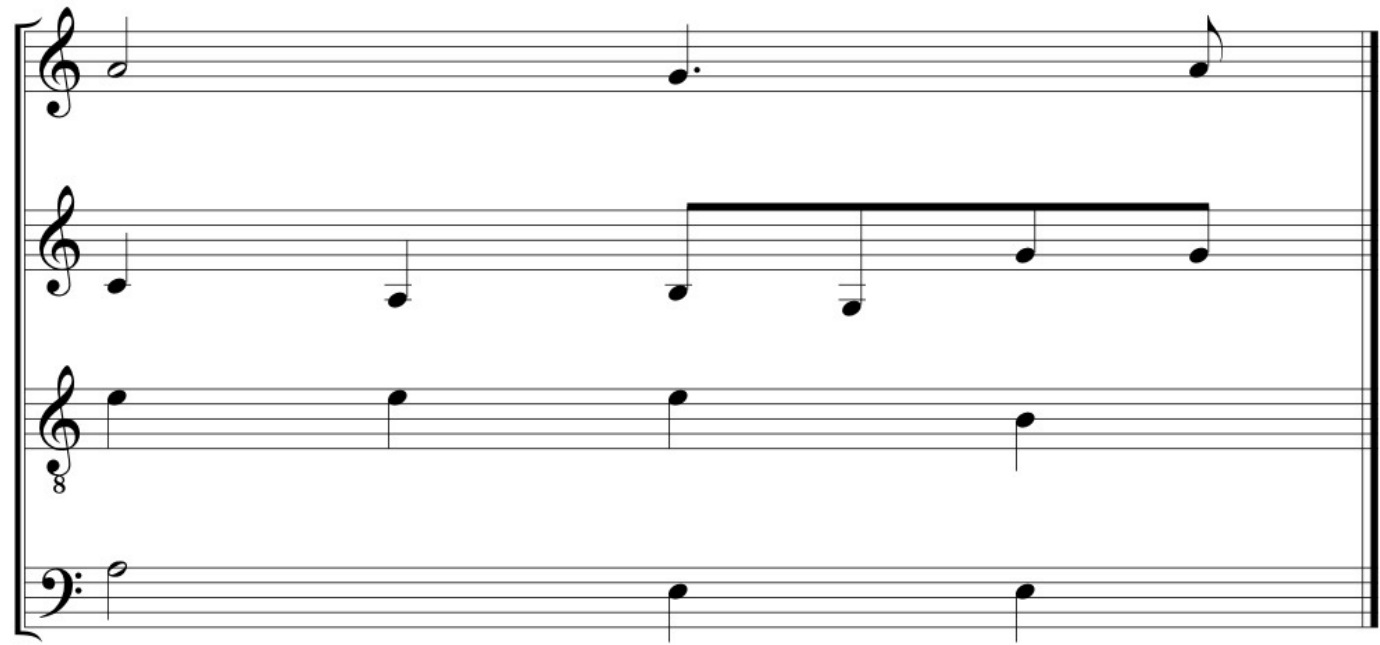

Figura 4.39 - Exemplo de alteração de duração de nota compasso 22 (grade).

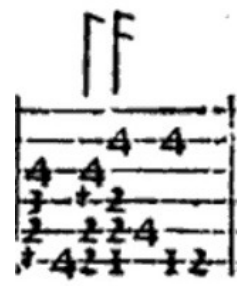

Figura 4.40 - Exemplo de alteração de duração de nota compasso 22 (entabulação).

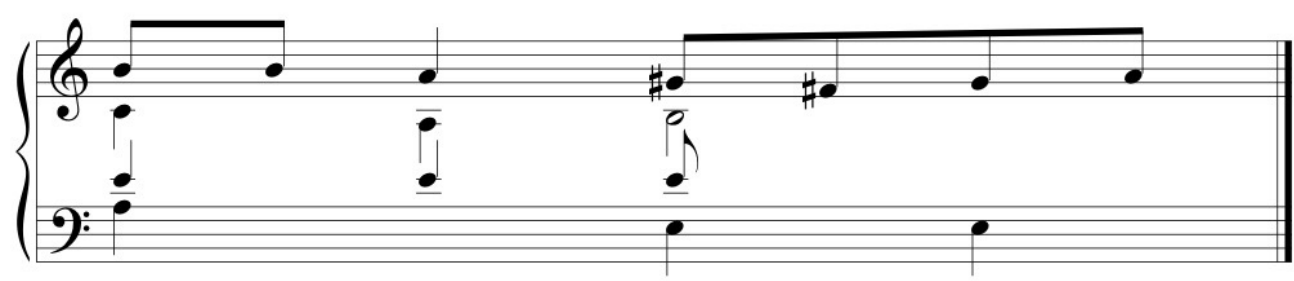

Figura 4.41 - Exemplo de alteração de duração de nota compasso 22 (transcrição da entabulação). 
Galilei também troca a posição das vozes, principalmente das internas. Nos compassos 15 e 16, a voz do alto, originalmente, canta uma frase que envolve as notas Mi 3, Fá 3 e Sol 3, enquanto a voz do tenor executa o âmbito de Lá 2 a Mi 3. Como pode ser visto nas figuras 4.40 e 4.41 , a versão de Galilei, na metade do compasso 15, parece trocar a posição das vozes do alto e do tenor de lugar. a voz do tenor, no entanto, pode ser ouvida com poucas alterações, a voz do alto, no entanto, faz um salto de sétima que resulta em um novo âmbito (Fá 2 a Mi 3). A troca de âmbito entre alto e tenor parece ser justificada pela impossibilidade de se executar as melodias do tenor, alto e cantus ao mesmo tempo. Trocar a oitava da voz nesse trecho pode ter sido uma opção feita para facilitar a execução ao alaúde. Como visto acima, trocar de oitava não era uma prática desconhecida por Galilei, uma vez que nessa mesma peça ele troca a oitava das notas do baixo que estão fora do registro do alaúde. Esse tipo de alteração também foi relatado por Minamino como uma prática de entabulação comum no século XVI.

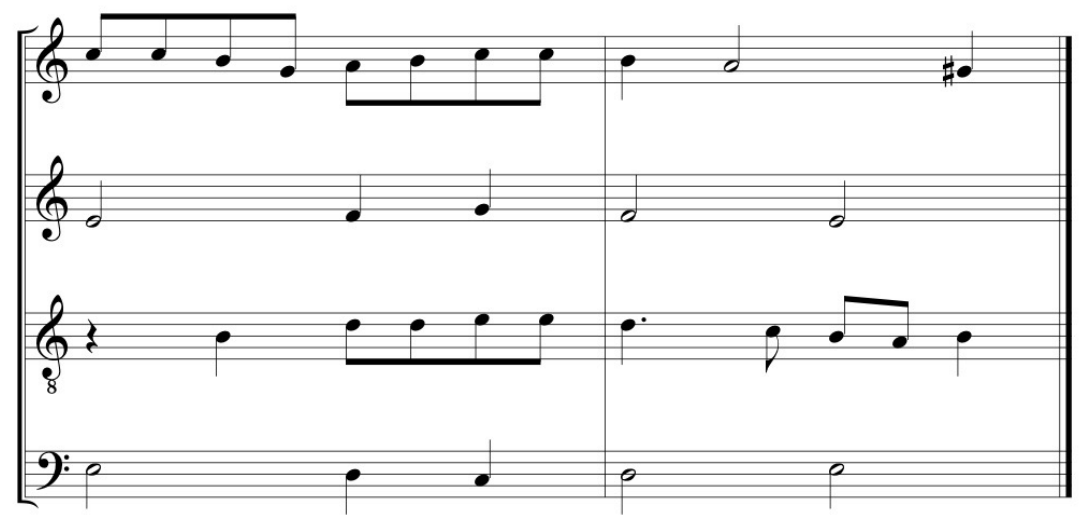

Figura 4.42 - Exemplo de voz oitavada compassos 15 e 16

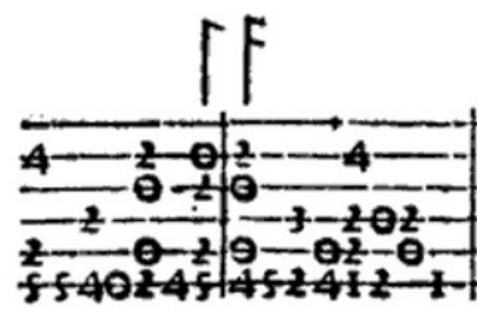

Figura 4.43 - Exemplo de voz oitavada compassos 15 e 16 (entabulação).

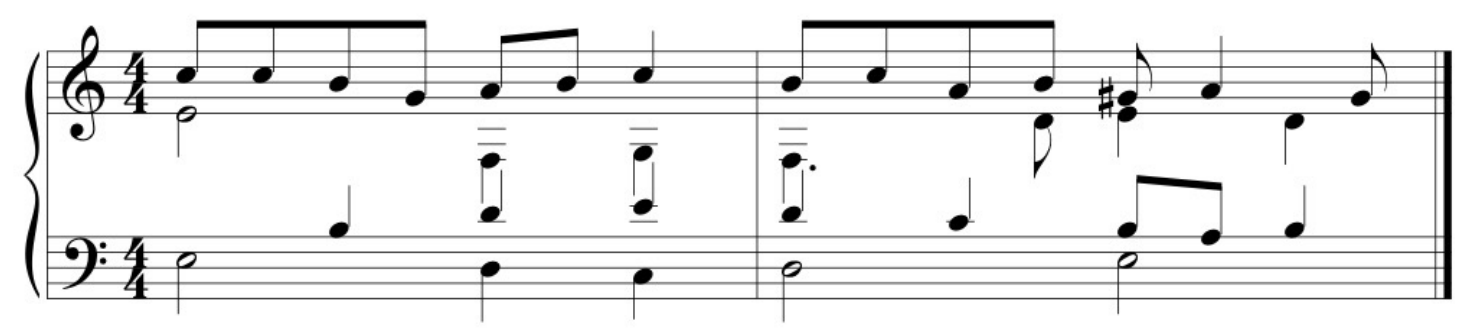

Figura 4.44 - Exemplo de voz oitavada compassos 15 e 16. 


\section{CAPÍTULO 5 - CONCLUSÃO}

O estudo do processo de entabulação de Vincenzo Galilei se mostra interessante, pois Galilei relaciona em seu tratado sobre o tema as técnicas de entabulação com a teoria musical da época. Com isso, pode-se perceber como a teoria aparece na prática musical, o que não é sempre possível de se relacionar diretamente nas músicas desse período. Convém também lembrar que Galilei é um personagem histórico importante, por congregar a atividade de alaudista com a de teórico, além de representar uma das principais tradições de entabulação do período e de ter proporcionado a base teórica para as obras desenvolvidas pelos membros da Camerata Fiorentina. Galilei proporcionou, em seu tratado, a base teórica e descreveu as técnicas de entabulação utilizadas por alaudistas como ele, Francesco da Milano e Giovanni Paolo Paladino.

Essa tradição, como foi visto nos capítulos anteriores, primava pela preservação das características da polifonia vocal que viria a ser entabulada. Ela certamente não era unívoca dentro da tradição alaudística do período. A outra corrente era aquela que pode ser bem exemplificada por Albert de Rippe e pelo tratado de Adrien Le Roy. Essa tradição tinha como objetivo outro tipo de entabulação, em que o original vocal era apenas uma espécie de ponto de partida para uma peça instrumental bastante rica em ornamentos, muitas vezes a polifonia original dificilmente pode ser reconhecida.

É certo que a convicção artística de Galilei coloca seu tratado em posição privilegiada para relacionar a prática instrumental com as teorias composicionais. Além do objetivo de utilizar as entabulações como meio de aprender as técnicas de composição vocal, o texto de Galilei permite visualizar como a teoria aparecia nas versões instrumentais. Como pode ser visto no capítulo cinco, mesmo se não existe a intensão de alterar o contraponto original não é possível entabular uma peça a quatro vozes para alaúde sem realizar algumas alterações. Mais além, a análise de Io mi son giovinetta confirma as constatações de Canguilhem (2001 p. 97-107) na análise da entabulação de Anchor che col partire, as alterações de Galilei são de dois tipos, o primeiro são de alterações necessárias, partes que não podem ser executadas no alaúde se mantidas como no original; o segundo são de alterações que Galilei faz para que a peça soe melhor no alaúde.

A análise realizada por Canguilhem, no entanto, não leva em consideração a teoria composicional da época, com isso não se pode comparar com precisão se as alterações feitas por Galilei alteram de fato a estrutura contrapontística original e em que medida. Para alcançar esse objetivo, a pesquisa buscou partir das relações feitas por Galilei no tratado para propor um roteiro 
de análise utilizado na realizada em Io mi son giovinetta no capítulo cinco. Buscou-se uma forma de análise que tivesse como foco as características apontadas por Galilei e a relação com as teorias composicionais.

$\mathrm{Na}$ análise da entabulação de Io mi son giovinetta, constatou-se que algumas características típicas das peças vocais do século XVI apareciam modificadas na entabulação do alaudista florentino. A primazia da relação entre a voz do tenor e cantus descrita por Bent não parece ser tão relevante para Galilei. Além de sua recomendação, ao tratar das notas que podem ser omitidas, de omitir notas das vozes internas, as principais cadências da peça foram alteradas justamente na voz do tenor, transfigurando uma das principais características das cadências da música. Em todas as três cadências principais as vozes do tenor e cantus terminavam em oitava, uma consonância perfeita. Galilei, nas três ocasiões, troca a resolução da voz do tenor, o que resulta em uma sexta menor com o cantus, uma consonância imperfeita. A oitava em todos esses casos encontra-se entre a voz do baixo e a do cantus. Essas duas evidências parecem indicar que Galilei considerava que existiam três vozes principais na peça baixo, tenor e cantus.

Por outro lado, as relações feitas por Galilei entre a teoria composicional e as técnicas de entabulação permitem uma compreensão mais detalhada do de como a primeira era compreendidas e utilizada por ele nas peças instrumentais. A relação entre as poste e a teoria modal mostra que, ao menos para Galilei, a tessitura em que a peça era entabulada era relevante e se relacionava à finalis do modo da peça. Essa parece ser a explicação mais convincente para o número de poste que Galilei descreve no tratado, o respeito ao contraponto original era mais do que simplesmente uma transcrição literal, ele representava uma transformação à estética que o entabulador julgava ser mais adequada ao alaúde.

Conclui-se também que as conexões feitas por Galilei entre a teoria modal e as entabulações de peças vocais permite a classificação dos tipos tonais delas. Os dois principais desafios para essa classificação eram e definição de uma clave e da armadura de clave, duas características que não se encontram nas tablaturas. Entretanto o quadro (fig. 4.25 e 4.26) que Galilei traz com as finalis, ambitus e claves de cada modo pode ser utilizado para relacionar a finalis da peça com o sistema de claves utilizado, mas a clave a ser utilizada deve ser a do baixo, uma vez que a do cantus não é indicada por Galilei. A armadura de clave, como foi visto no capítulo 5, pode ser definida por meio da análise da realização de ficta na entabulação.

A comparação entre o tratado e a entabulação de Galilei levanta questões importantes acerca da relevância histórica desse repertório. No século XVII, o alaúde e outros instrumentos similares têm uma função importante como instrumentos de baixo contínuo. A música desse período estava 
centrada na relação entre o baixo e a voz solista. O estilo de entabulação de Galilei, enquanto ferramenta de aprendizado composicional, pode ter sido uma influência importante. Para aprofundar mais essa questão, seria necessário um maior número de análises que demonstrassem o quão difundidas eram as técnicas de entabulação descritas por Galilei em seu tratado. Mas as teorias defendidas por Galilei e seu posicionamento dentro de uma importante tradição de entabuladores parece indicar que as entabulações de alaúde tiveram um papel relevante nas transformações pelas quais a música italiana passava no final do século XVI. 


\section{REFERÊNCIAS}

ADRIAENSEN, Emanuel. Novum pratum musicum longe amoenissimum. Antuérpia: Petrus Phalesius \& Ioanni Bellero, 1992.

ARGONDIZZA, Peter. Ornamented intabulations and derived fantasias: parody, imitatio, and genre in Vincenzo Galilei's lute arrangements of Alessandro Striggio's Nasce la pena mia. In: Renaissance society of america annual conference, 2013, San Diego. Disponível em: $<$ http:// s3.amazonaws.com/academia.edu.documents/

37023066/1._RSA_Conference_Paper_Peter_Argondizza.pdf?

AWSAccessKeyId=AKIAJ56TQJRTWSMTNPEA\&Expires $=1473313466 \&$ Signature $=$ ZtpkrSRj74i 7q60uSIQCaXHvfwc\%3B\%20filename\%3DOrnamented_Intabulations_and_Derived_Fa.pdf $>$. Acesso em 8 de set. de 2016.

ASSIS, Ana Cláudia de et al. Música e História: desafios da prática interdisciplinar. In: BUDASZ, Rogério (Org.). Pesquisa em música no Brasil: métodos, domínios, perspectivas. Goiânia:

ANPPOM, 2009. p. 5-39.

BARBIERI, Patrizio. "Chiavette" and modal transposition in Italian practice. Recercare, v. 3, 1991. Disponível em: <http://www.jstor.org/stable/41701071>. Acesso em 23 de ago. 2016.

BENT, Margaret. The Grammar of Early Music: preconditions for analysis. In: JUDD, Cristle Collins (Ed.). Tonal structures in early music. Nova York: Garland Publishing, 1998.

. Musica Ficta. In: Grove music online. Disponível em: $<\mathrm{http}: / /$

www.oxfordmusiconline.com:80/subscriber/article/grove/music/19406>. Acesso em 18 de abr. 2016.

. Res facta and cantare super librum. In: Journal of the american musicological society, $\mathrm{n}$. 3, v. 36, 1983. Disponível em: <http://www.jstor.org/stable/831232>. Acesso em 20 ago. de 2016.

BERMUDO, Juan. El libro llamado declaración de instrumentos musicales, Osuna: Juan de Leon, 1555.

BLACKBURN, Bonnie J. On compositional process in the fifteenth century. In: Journal of the american musicological society, n. 2, v. 40, 1987. Disponível em: <http://links.jstor.org/sici? sici $=0003-0139 \% 28198722 \% 2940 \% 3$ A2\%3C210\%3AOCPITF\%3E2.0.CO\%3B2-0>. Acesso em 16 jan. de 2011.

The dispute about harmony c. 1500 and the creation of a new style. In: BLACKBURN, Bonnie J.; CEULEMANS, Anne-Emmanuelle. Théorie et analyse musicales 1450-1650. LouvainLa-Neuve: Raymond Brulet, 2001.

CANGUILHEM, Philippe. Fronimo de Vincenzo Galilei, Paris: Minerve, 2001.

. Monodia e contrappunto a Firenze nel cinquecento. In: MENCHELLI-BUTTINI, Francesca (Ed.). La monodia toscana alle soglie del XVII secolo. Pisa: Edizioni ETS, 2007. 
CROCKER, Richard L. Discant, counterpoint, and harmony. In: Journal of the america musicological society, n. 1, v. 15, 1962. Disponível em: <http://www.jstor.org/stable/830051>. Acesso em: 12 jul. de 2016.

DA MILANO, Francesco. Intabolatura de liuto di M. Francesco da Milano et Perino Fiorentino suo discipulo. Veneza: Antonio Gardano, 1562.

DART, Thurston; MOREHEN, John; RASTALL, Richard. Tablature. In: Grove music online. Disponível em: <http://www.oxfordmusiconline.com:80/subscriber/article/grove/music/27338>. Acesso em 28 dez. 2015.

DINIZ, Célia Regina; SILVA, Iolanda Barbosa da. Metodologia científica, Natal: EDUEP, 2008.

DREYFUS, Laurence. Early music defended against its devotees: a theory of historical performance in the twentieth century. In: The musical quartely, n. 3, v. 69, 1983. Disponível em: <http:// www.jstor/stable/742175>. Acesso em 8 nov. 2016.

FERAND, Ernest T. What is "res facta"?. In: Journal of the american musicological society, n. 3, v. 10, 1957. Disponível em: <http://www.jstor.org/stable/829784> Acesso em 20 ago. 2016.

FUENLLANA, Miguel de. Orphenica lyra, Sevilla, Martin de Montesdoca, 1554.

GALILEI, Vincenzo. Fronimo. Veneza: Girolamo Scotto, 1584.

GALILEI, Vincenzo. Fronimo. Veneza: Girolamo Scotto, 1568.

GALILEI, Vincenzo. Fronimo. Tradução de Carol Mcclintock. Neuhausen-Stuttgart: AIM HänslerVerlag, 1985.

GALILEI, Vincenzo. Dialogo della musica antica et della moderna. Florença: Giorgio Marescotti, 1581 .

GOEHR, Lydia. Writing music history. History and Theory, n. 2, v. 31, 1992. Disponível em: $<$ http://www.jstor.org/stable/2505596>. Acesso em 01 dez. 2012.

GOEHR, Lydia. The imaginary museum of musical works: an essay in the philosophy of music, Nova York, Oxford university press, 2007.

GÖLLNER, Marie-Louise. On the process os lute intabulation in the sixteenth century. In: LEUCHTMANN, H.; MÜNSTER, R. Ars iocundissima: Festschrift für Kurt Dorfmüller zum 60. geburtstag, Tutzing: H. Schneider, 1984.

JUDD, Cristle Collins. Some problems of pre-baroque analysis: an examination of Josquin's "Ave Maria... Virgo Serena”. In: Music analysis, n. 3, v. 4, 1985. Disponível em: <http://www.jstor.org/ stable/854096>. Acesso em 13 de fev. de 2016.

JUDD, Cristle Collins. Rennaissance modal theory: theoretical, compositional, and editorial prespectives. In: CHRISTENSEN, Thomas. The cambridge history of western music theory, Cambridge: Cambridge University Press, 2002.

KERMAN, Joseph. Musicologia, São Paulo, Matins Fontes, 1987. 
KUIJKEN, Barthold. Notation is not the music, Bloomington, Indiana University Press, 2013.

KURTZMAN, Jeffrey G. Tones, modes, clefs and pitch in Roman cyclic magnificats of the 16th century, Early Music, n. 4, v. 22, 1994. Disponível em: <http:/www.jstor.org/stable/3128194>. Acesso em 22 de ago. 2016.

LE ROY, Adrien. Les instructions pour le luth. Editado por Jean Jaquot; Pierre-Yves Sordes e JeanMichel Vaccaro. Paris: Éditions du centre national de la recherche scientifique, 1977.

LOWINSKY, Edward E. On the use of scores by sixteenth-century musicians. In: Journal of the american musicological society, n. 1, v. 1, 1948. Disponível em: $<\mathrm{http}: / / \mathrm{www}$.jstor.org/stable/ 829661>. Acesso 15 jul. de 2016.

MINAMINO, Hiroyuki. Sixteenth-century lute treatises with emphasis on process and techniques of intabulation. Tese (Doutorado em Música) - Department of Music, The University of Chicago, Chicago, 1988.

NEUSIDLER, Hans. Ein newgeordent künstlich Lautenbuch in zwen Theyl getheylt: der erst für die anfahenden Schuler, Nurenberg, 1536.

OWENS, Jessie Ann. Composers at work: the craft of musical composition 1450-1600. Nova York: Oxford University Press, 1998.

PALISCA, Claude V. Vincenzo Galilei's counterpoint treatise: a code for the "seconda pratica", Journal of the american musicological society, n. 2, v. 9, 1956. Disponível em: <http:// www.jstor.org/stable/829674>. Acesso em 12 de jul. de 2012.

PERKINS, Leeman L. Mode and structure in the masses of Josquin. In: Journal of the american musicological society, n. 2, v. 26, 1973. Disponível em: <http://www.jstor.org/stable/830665>. Acesso em: 14 jul. de 2016.

POWERS, Harold. Tonal types and modal categories in renaissance polyphony. In: Journal of the american musicological society, n. 3, v. 34, 1981. Disponível em: < http://www.jstor.org/stable/ 831189>. Acesso em 26 de abr. de 2016.

POWERS, Harold; WIERING, Frans. Mode. In: Grove music online, 2007. Disponível em: < http:// www.oxfordmusiconline.com:80/subscriber/article/grove/music/43718pg3>. Acesso em 11 de mai. de 2016.

REMPP, Frieder. Die Kontrapunkttraktate Vincenzo Galileis. Köln: Arno Volk Verlag Hans Gerig K. G., 1980.

RIVERA, Benito. Theory ruled by practice: Zarlino's reversal of the classical system of proportions. In: Indiana theory review, v. 16, 1995. Disponível em: <http://hdl.handle.net/ 2022/3747>.

SACHS, Klaus-Jürgen. Counterpoint. Grove music online, Disponível em: <http:// www.oxfordmusiconline.com:80/subscriber/article/grove/music/06690>. Acesso em 28 de dez. 2015. 
SMITH, Anne. The performance of 16th century music: learning from the theorists. Nova York: Oxford University Press, 2011.

SPINACINO, Francesco. Intavolatura de liuto libro primo. Veneza: Ottaviano Petrucci, 1507.

TREITLER, Leo. What kind of story is history?. In: 19th-century music, v. 7, n. 3, 1984. Disponível em: <http://www.jstor.org/stable/746388>.

. The historiography of music: issues of past and present. In: COOK, Nicholas (Ed.);

EVERIST, Mark (Ed.). Rethinking music. New York: Oxford University Press, 2001. p. 356-377.

. History and Music. In: New literary history, v. 21, n. 2, 1990. Disponível em: $<$ http://

www.jstor.org/stable/469254>.

VACCARO, Jean-Michel. La musique de luth en France au XVI siècle. Paris: Éditions du centre national de la recherche scientifique, 1981.

WARD, John. The use of borrowed material in 16th-century instrumental music. In: Journal of the american musicological society, v. 5, n. 2, 1952. Disponível em: $<$ http://www.jstor.org/stable/ 830181>. Acesso em 30 de set. de 2015.

WIERING, Frans. Internal and external views of the modes. In: JUDD, Cristle Collins (Ed.). Tonal structures in early music. Nova York: Garland Publishing, 1998.

. The language of the modes. Nova York: Routledge, 2001.

ZARLINO, Gioseffo. Le istitutioni harmoniche. Veneza, 1558.

. Sopplimenti musicali, Francesco de Franceschi, 1588.

. On the modes: part four of Le institutioni harmoniche. Tradução de Vered Cohen. New

Haven: Yale University Press, 1983. 


\section{APÊNDICE}

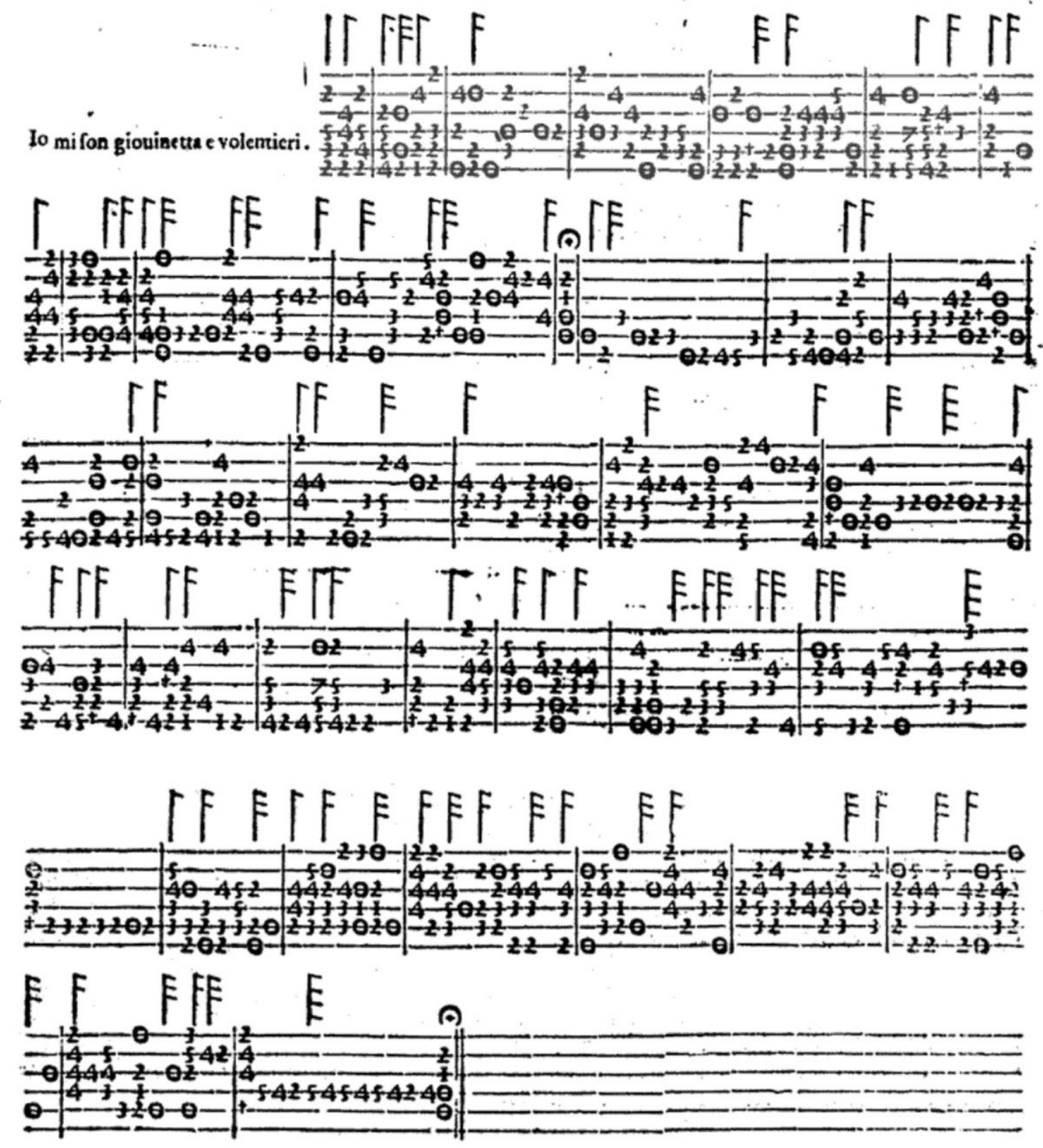

Figura A.1 - Entabulação de Io mi son giovinetta

(GALILEI, 1584, p. 56-57). 
Io mi son giovinetta
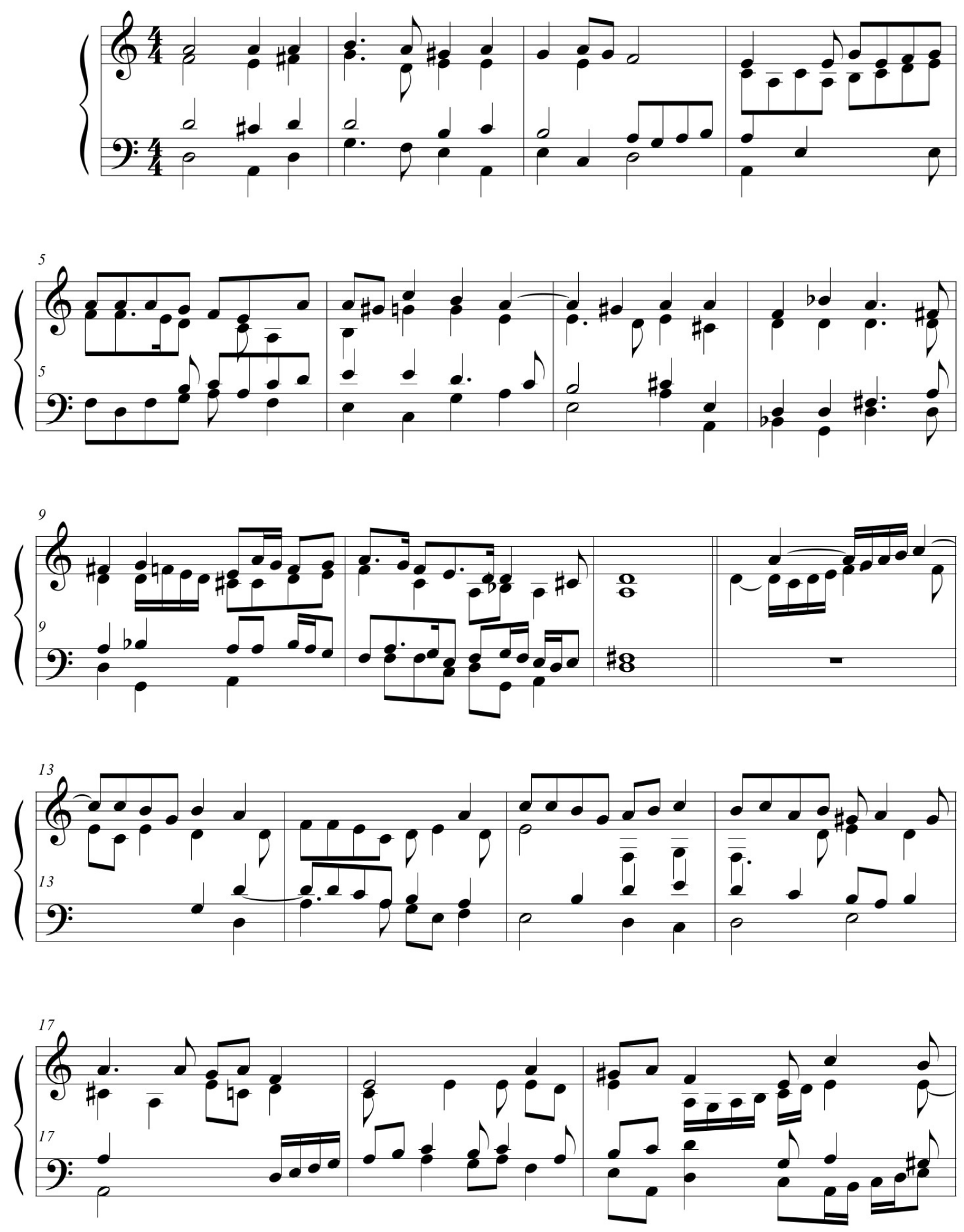

Figura A.2 - Transcrição da entabulação de Io mi son giovinetta (p.1). 

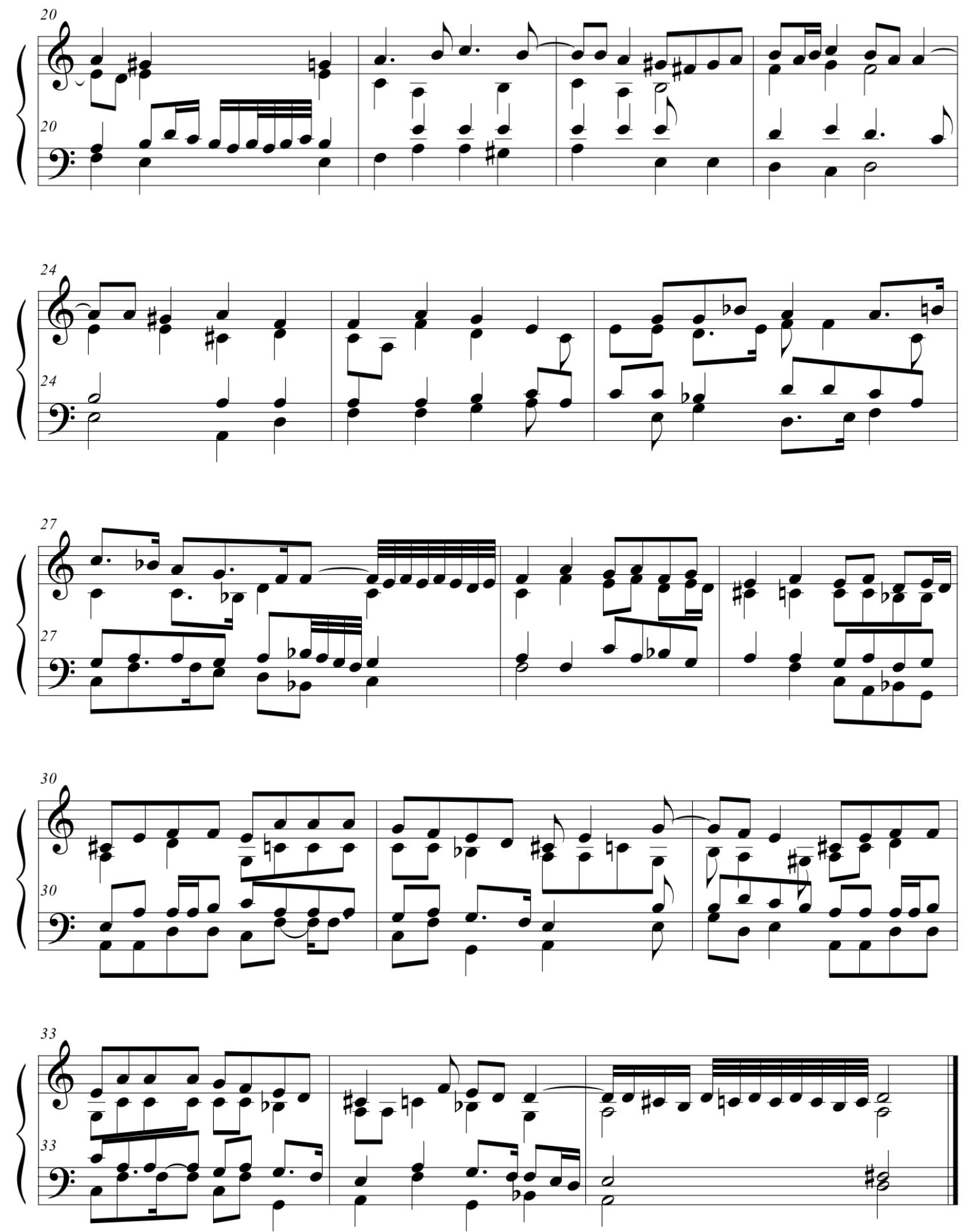

Figura A.3 - Transcrição da entabulação de Io mi son giovinetta (p.2). 


\section{Io mi son giovinetta}

Alla quarta bassa

Domenico Maria Ferrabosco (Bologna 1513-1574)
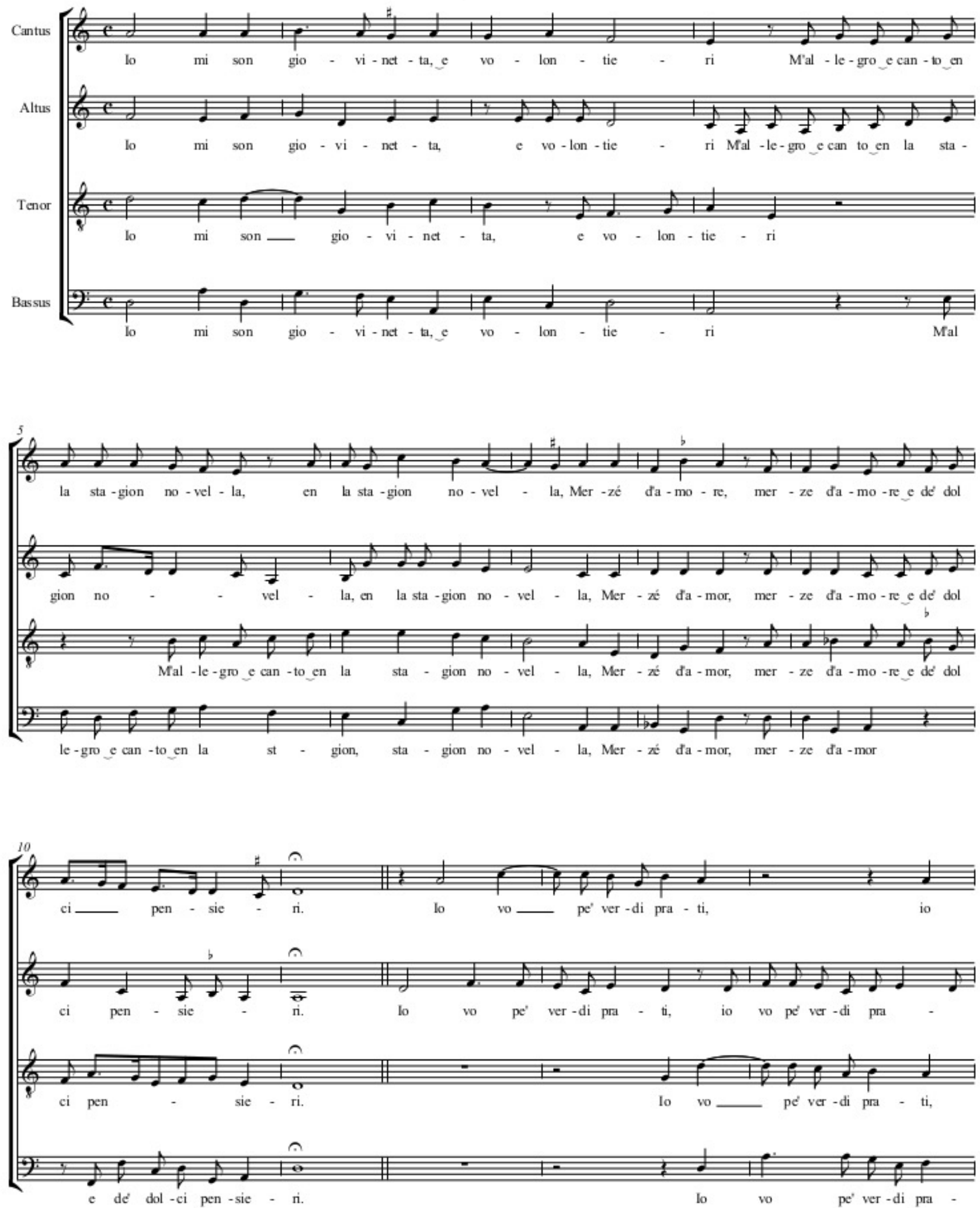

Figura A.4 - Grade de Io mi son giovinetta alla quarta bassa (p.1). 
Ferrabosco - Io mi son giovinetta
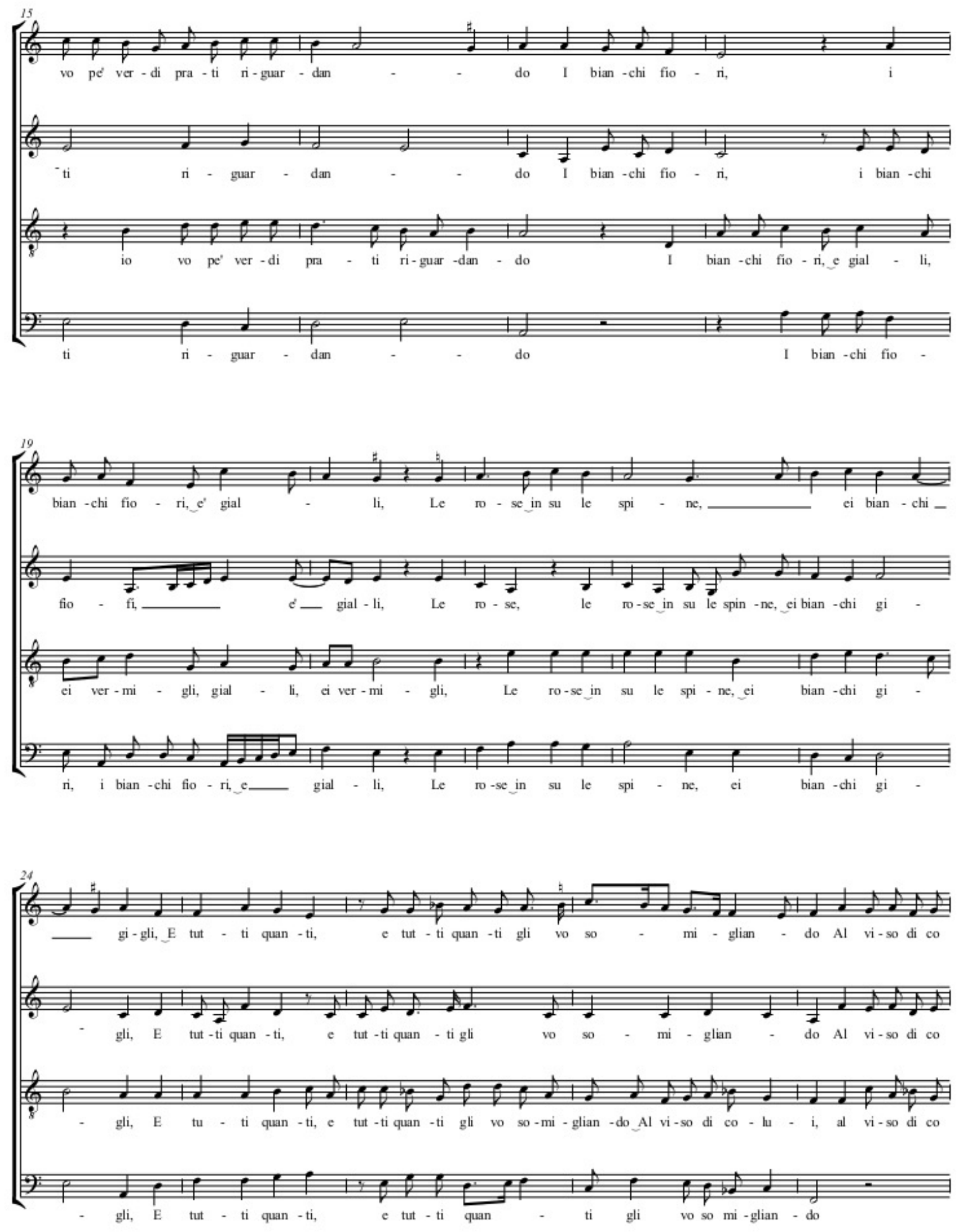

Figura A.5 - Grade de Io mi son giovinetta

alla quarta bassa (p.2). 
Ferrabosco - Io mi son giovinetta
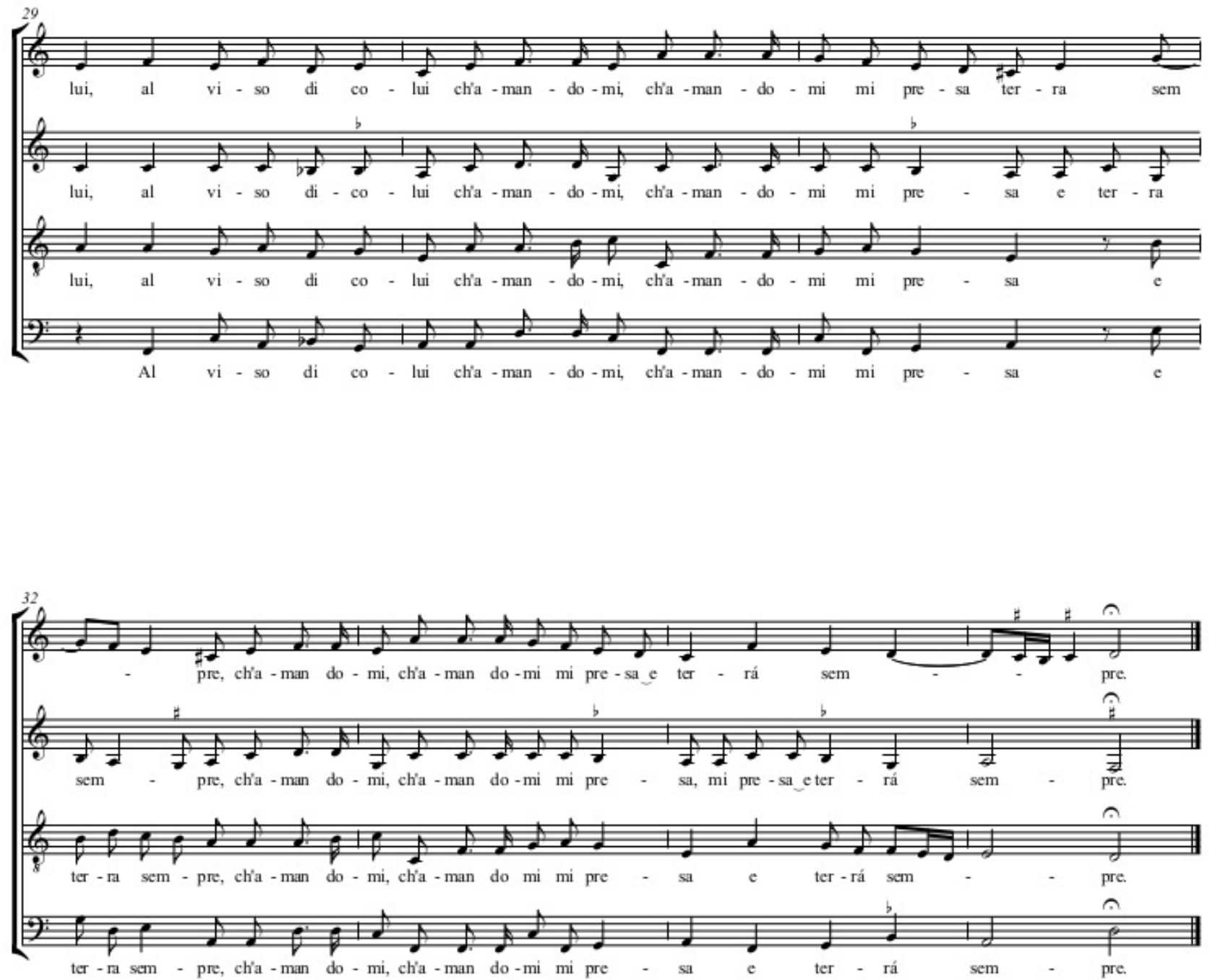

Figura A.6 - Grade de Io mi son giovinetta alla quarta bassa (p.3). 

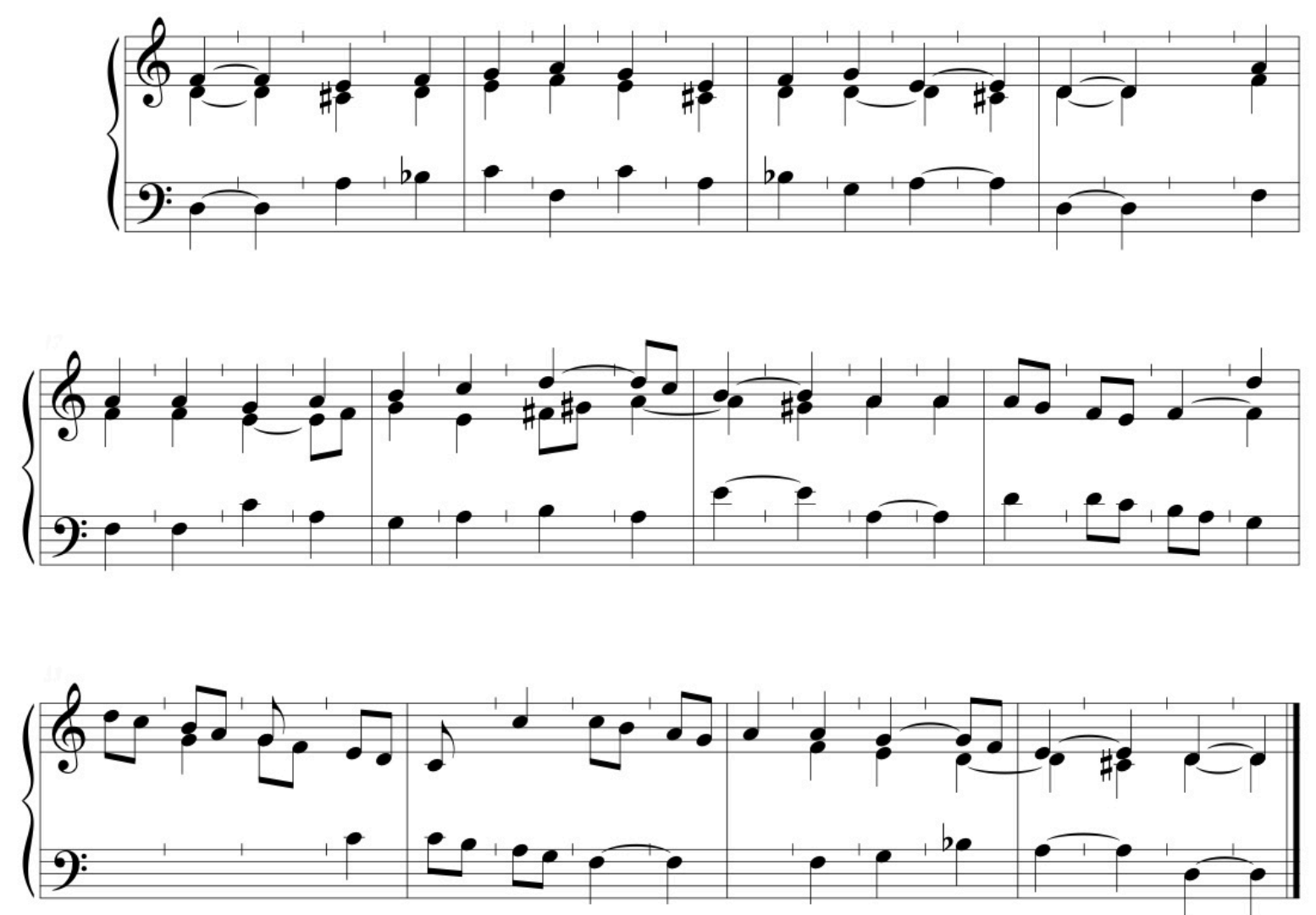

Figura A.7 - Transcrição da entabulação intermediária de Adriansen (ADRIANSEN, 1592).
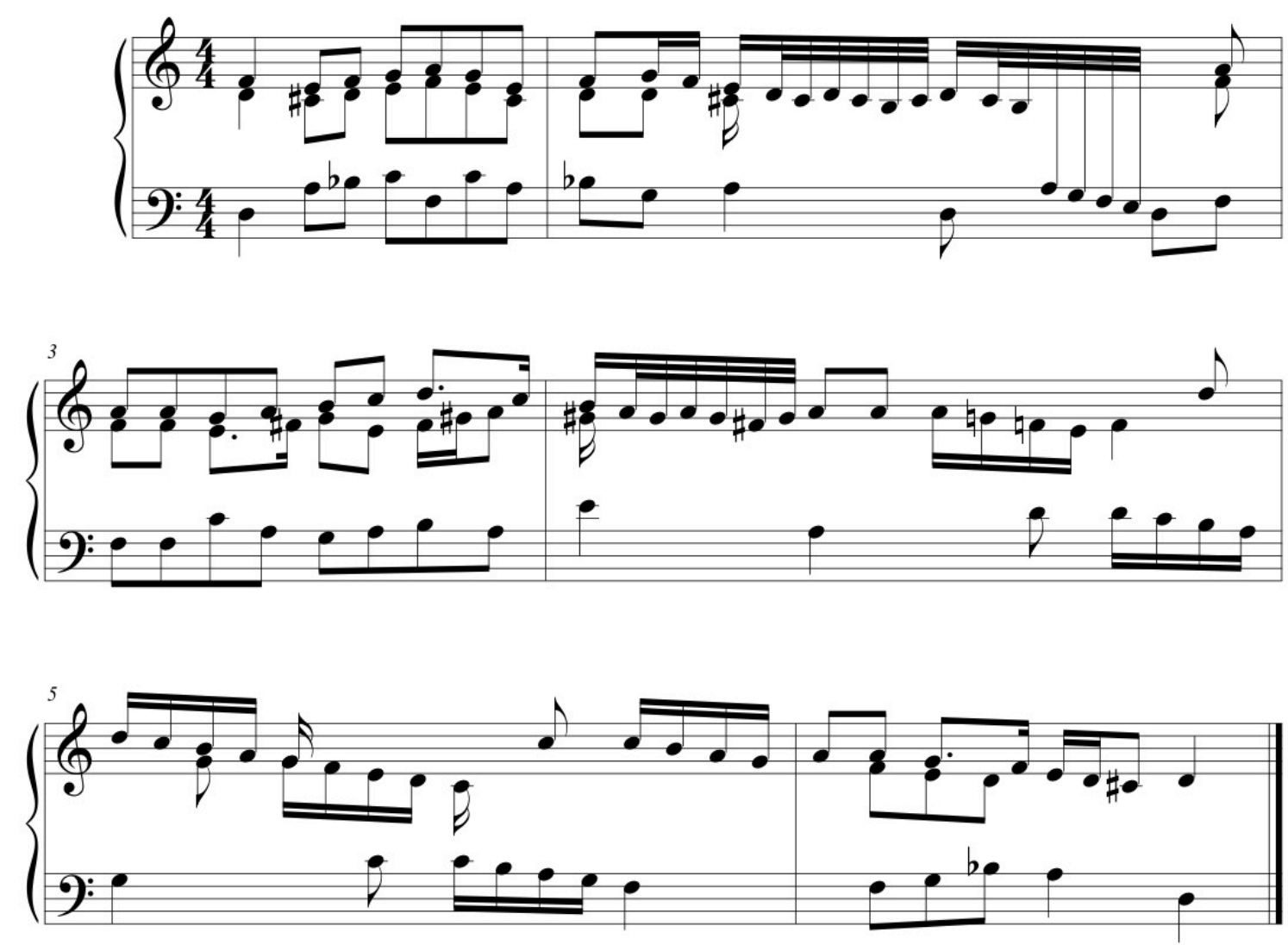

Figura A.8 - Transcrição da entabulação ornamentada de Adriansen (ADRIANSEN, 1592). 


\section{Helas quel Jour}
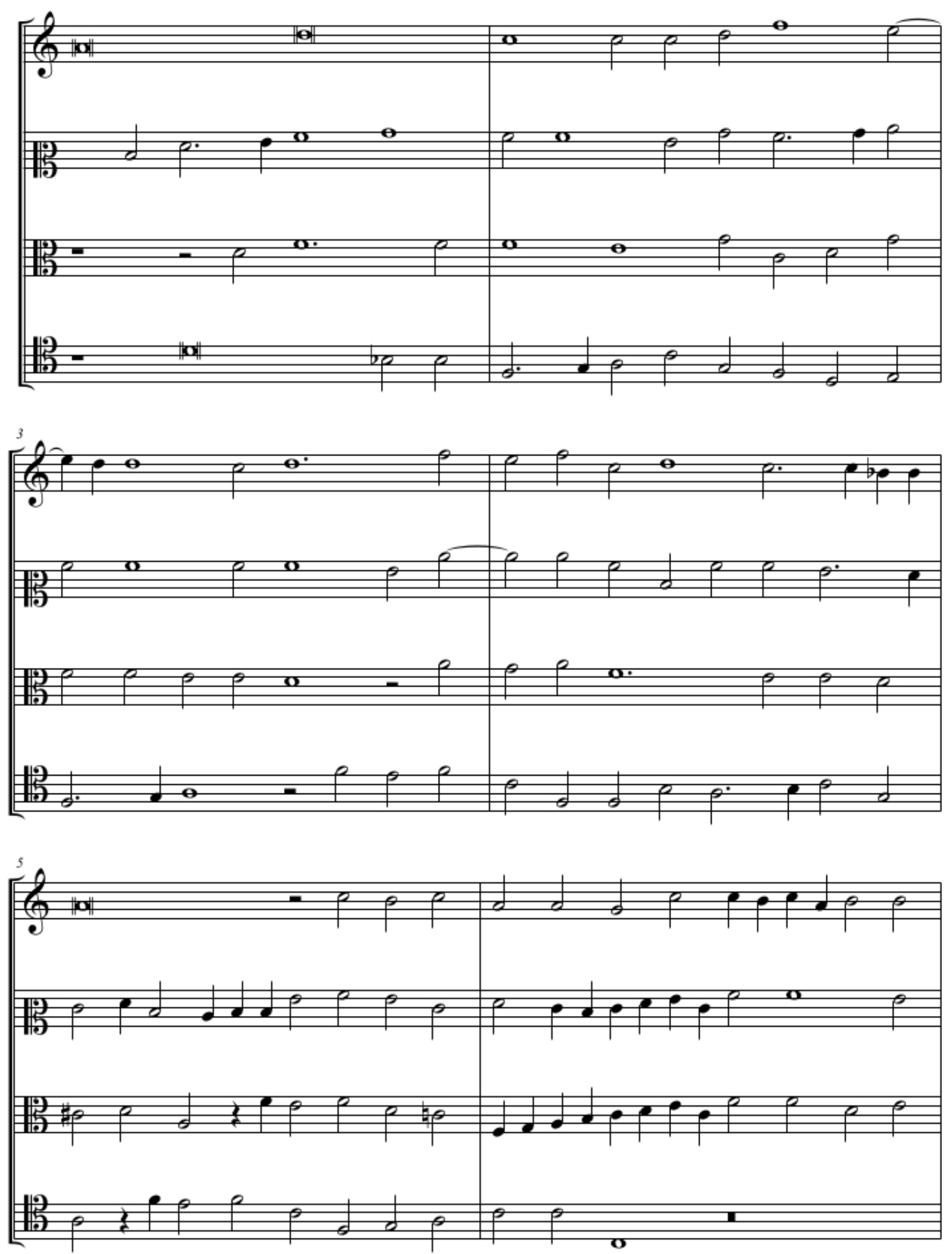

Figura A.9 - Helas quel jour transcrição da grade p.1

(Bayerische Staatsbibliothek de Munique, Ms. Mus 2986). 
Helas quel Jour
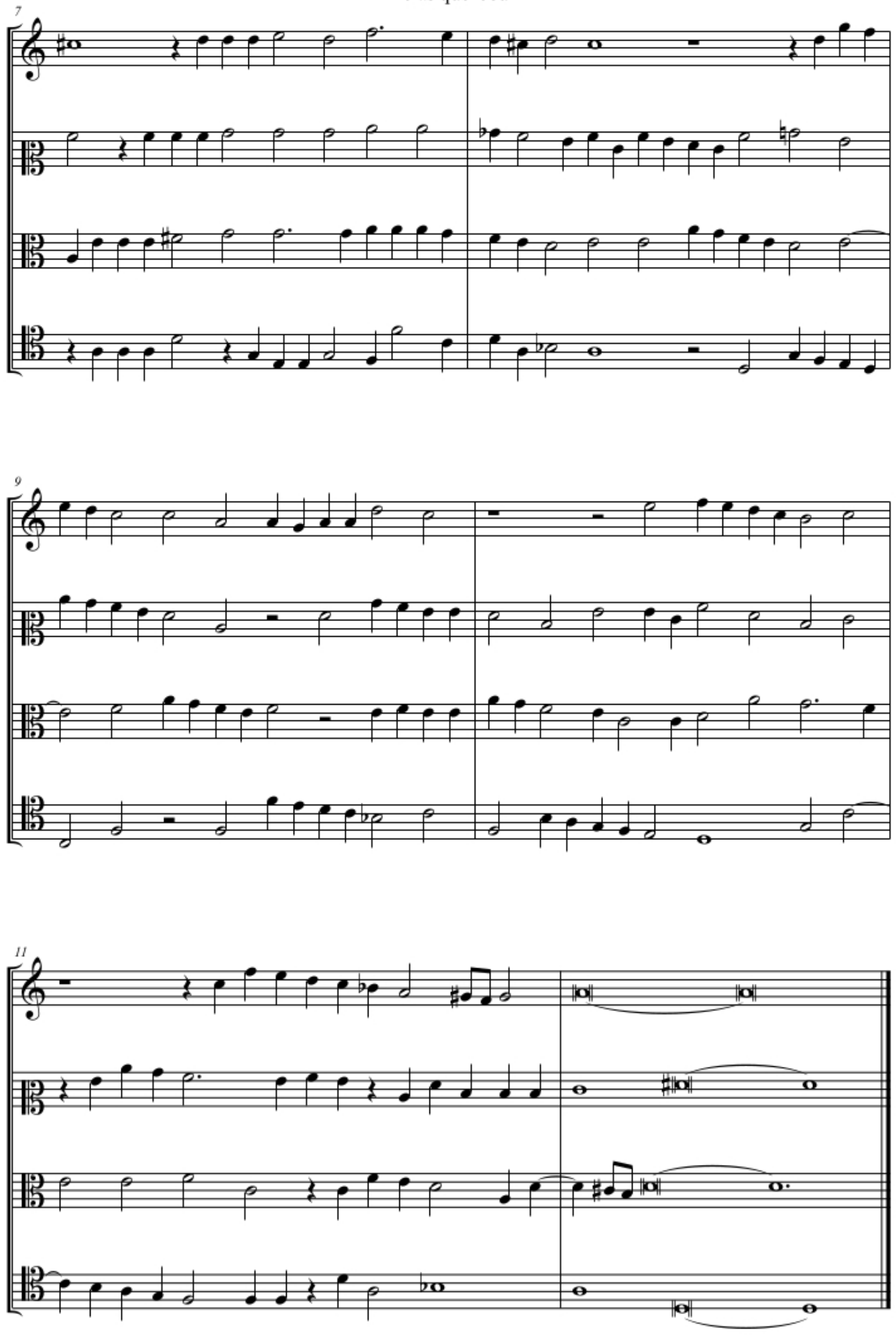

Figura A.10 - Helas quel jour transcrição da grade p. 2

(Bayerische Staatsbibliothek de Munique, Ms. Mus 2986). 


\section{Helas quel jour}
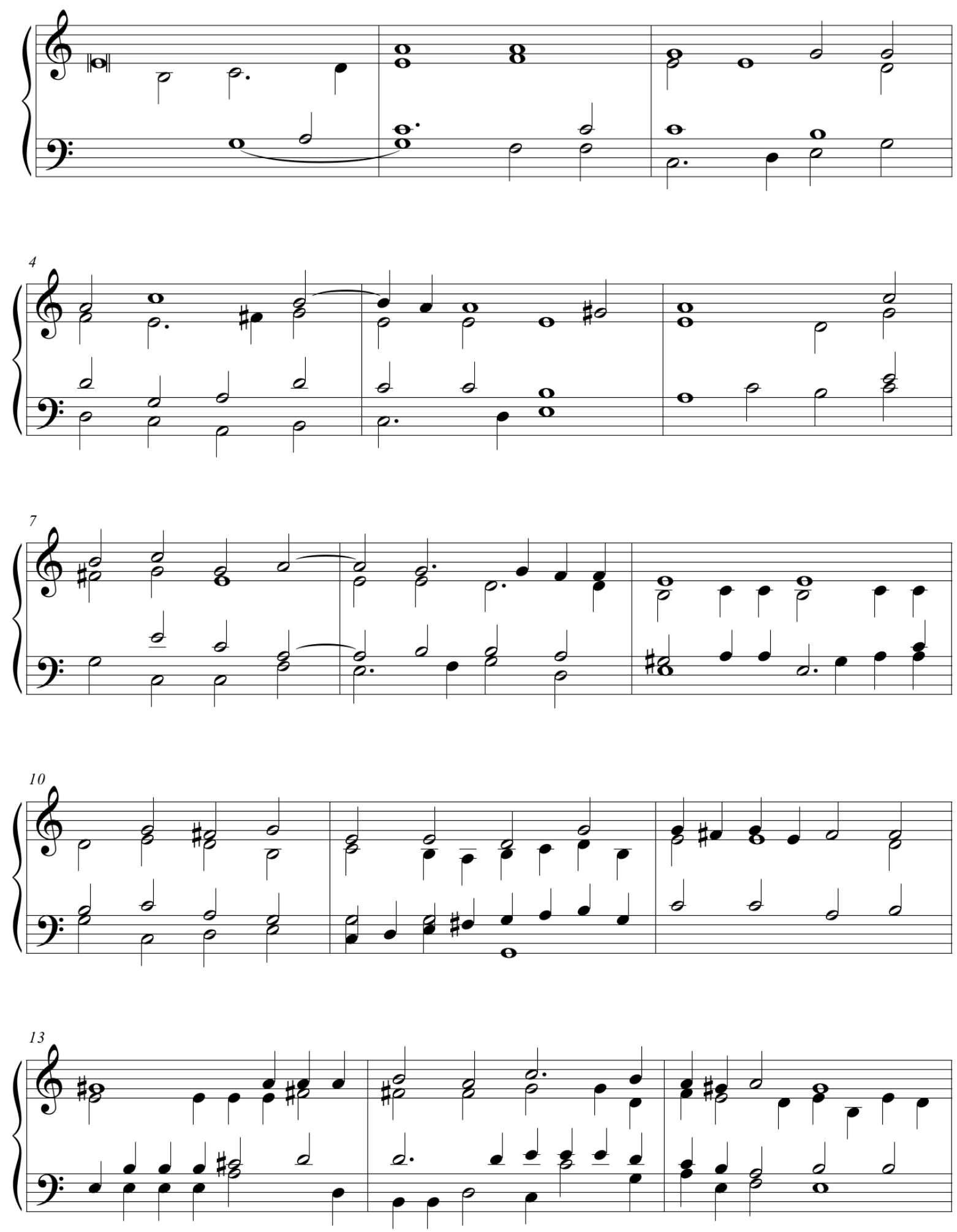

Figura A.11 - Helas quel jour transcrição da entabulação p.1

(Bayerische Staatsbibliothek de Munique, Ms. Mus 2986). 
Helas quel jour
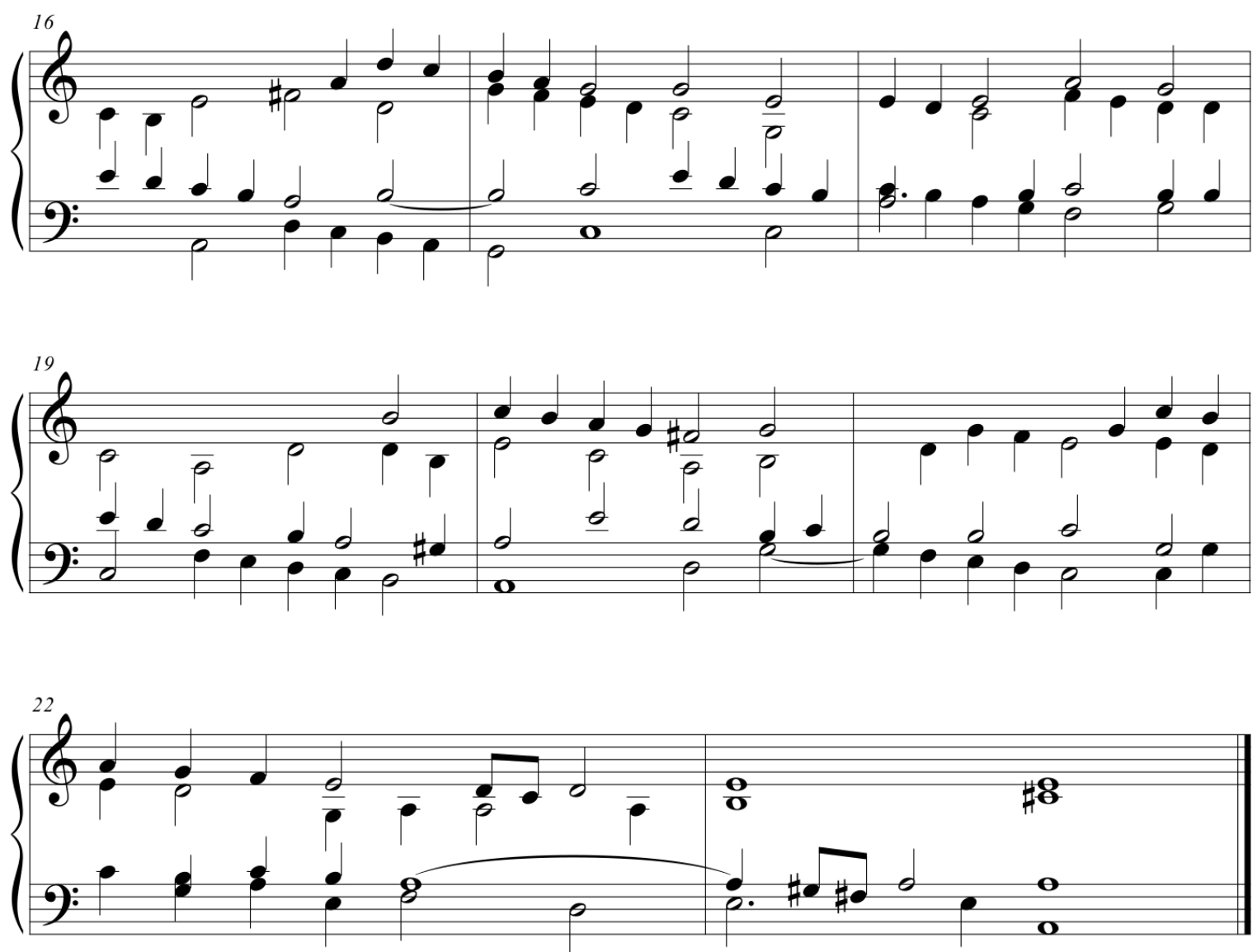

Figura A.12 - Helas quel jour transcrição da entabulação p.2

(Bayerische Staatsbibliothek de Munique, Ms. Mus 2986). 